DOC.20041118.0005

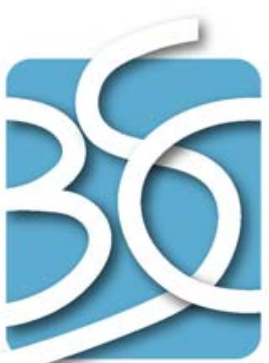

BECHTEL SAIC COMPANYLC

QA: QA

ANL-EBS-MD-000038 REV 01

November 2004

NOTICE OF OPEN CHANGE DOCUMENTS - THIS DOCUMENT (PARENT) IS IMPACTED BY THE LISTED CHANGE DOCUMENTS (CHILDREN) AND CANNOT BE USED WITHOUT THEM.

1) ACN-001, EFFECTIVE 05/03/2005

2) ACN-002, EFFECTIVE 06/07/2005

\title{
Evaluation of Potential Impacts of Microbial Activity on Drift Chemistry
}

Prepared for:

U.S. Department of Energy

Office of Civilian Radioactive Waste Management

Office of Repository Development

1551 Hillshire Drive

Las Vegas, Nevada 89134-6321

Prepared by:

Bechtel SAIC Company, LLC

1180 Town Center Drive

Las Vegas, Nevada 89144

Under Contract Number

DE-AC28-01RW12101 


\section{DISCLAIMER}

This report was prepared as an account of work sponsored by an agency of the United States Government. Neither the United States Government nor any agency thereof, nor any of their employees, nor any of their contractors, subcontractors or their employees, makes any warranty, express or implied, or assumes any legal liability or responsibility for the accuracy, completeness, or any third party's use or the results of such use of any information, apparatus, product, or process disclosed, or represents that its use would not infringe privately owned rights. Reference herein to any specific commercial product, process, or service by trade name, trademark, manufacturer, or otherwise, does not necessarily constitute or imply its endorsement, recommendation, or favoring by the United States Government or any agency thereof or its contractors or subcontractors. The views and opinions of authors expressed herein do not necessarily state or reflect those of the United States Government or any agency thereof. 
QA: QA

\section{Evaluation of Potential Impacts of Microbial Activity on Drift Chemistry ANL-EBS-MD-000038 REV 01}

November 2004 


\begin{tabular}{|l|l|l|}
\hline OCRWM & Scientific Analysis Signature Page/ Change History & Page iii \\
\cline { 3 - 3 } & & 1 . Total Pages: 104 \\
\hline
\end{tabular}

\begin{tabular}{|c|c|c|c|}
\hline \multicolumn{4}{|l|}{$\begin{array}{l}\text { 2. Scientlic Analysis Tille } \\
\text { Evaluation of Potential lmpact }\end{array}$} \\
\hline \multicolumn{4}{|c|}{ 3. Ol (inciuding Revision Number) } \\
\hline \multicolumn{4}{|c|}{ ANL-EBS-MD-000038 REV O1 } \\
\hline \multicolumn{2}{|l|}{ 4. Total Appendices } & \multirow{2}{*}{\multicolumn{2}{|c|}{$\begin{array}{l}\text { 5. Number of Pages in Each Appendix } \\
\text { N/A }\end{array}$}} \\
\hline \multirow[t]{2}{*}{$\mathrm{N} / \mathrm{A}$} & \multirow{2}{*}{\multicolumn{2}{|c|}{\begin{tabular}{l|l} 
N/A \\
\end{tabular}}} & \\
\hline & & & Date \\
\hline 5 Originator & Y. Wang & 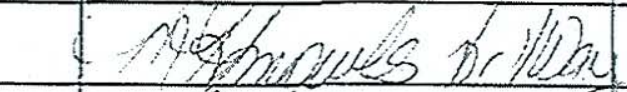 & i) 18104 \\
\hline 7. checker & R. Walsh & 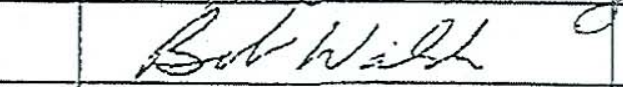 & $11 / 18 / 04$ \\
\hline 8. QE? & Charlie Warren & Charlir Lave & $11 / 18 / 04$ \\
\hline 9. Responsible Menagetiluead & W. Jaros & Wendy faver & $11 / 18 / 04$ \\
\hline 10. Responsible Manager & E. Hardin & Clfardu 1 & $11 / 18 / 04$ \\
\hline \multirow{2}{*}{\multicolumn{4}{|c|}{$\begin{array}{l}\text { A.J. Francis assisted with preparation of this revision, particularly Sections } 6.1 .1,6.1 .4,6.4 .7 \text {, and } 6.5 .3 \text {. R. Wyalsh assisted with } \\
\text { preparation of Sections through } 4 \text { and } 7 \text {. } \\
\text { R. Walsh checkel Sections } 5 \text { and } 6 \text {. John Del Mar ehecked the remainder of the document. } \\
\text { JBV - } 3763 \text {. TBV-4227, and TBV-4509 will be canceled upon approval of this revision. }\end{array}$}} \\
\hline & & & \\
\hline \multicolumn{4}{|c|}{ Change History } \\
\hline 12. Revision No. & \multicolumn{3}{|c|}{ 13. Descriplion of Change } \\
\hline REVOO & \multicolumn{3}{|l|}{ Inilial issue } \\
\hline REVOOICNOI & \multicolumn{3}{|c|}{ 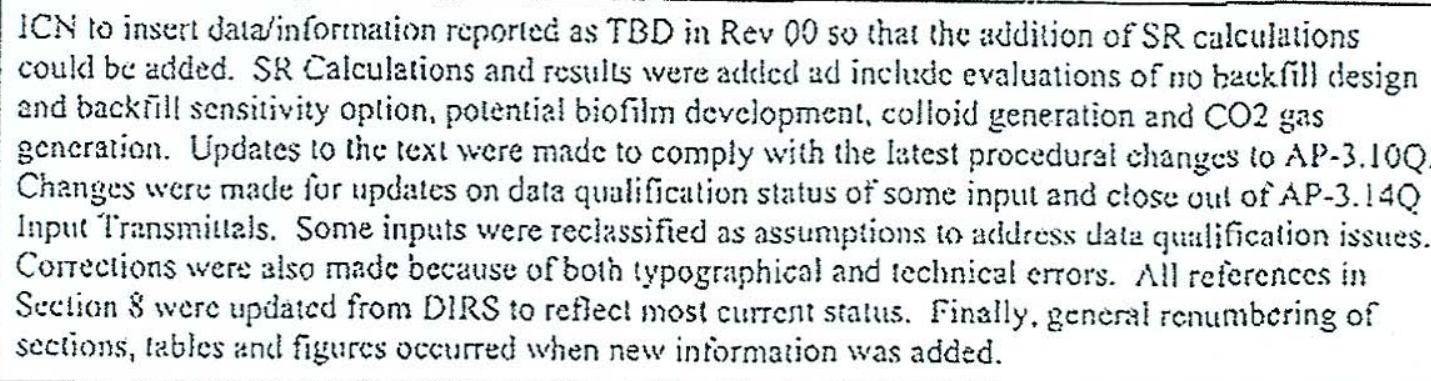 } \\
\hline REVOI & \multicolumn{3}{|c|}{$\begin{array}{l}\text { Complete revision to support the TSPA-LA. Title changed fiom 'In-Drift Microbial Comnunities' to } \\
\text { reflect new focus. This revision addresses Regulatory linegration Team comments CR } 147 \text { (model } \\
\text { validation). CR } 164 \text { (incorrect datum), CR } 2478 \text { (possible errors in DOE RW-184), and CR } 659 \\
\text { (technical crors). }\end{array}$} \\
\hline
\end{tabular}




\section{INTENTIONALLY LEFT BLANK}




\section{CONTENTS}

\section{Page}

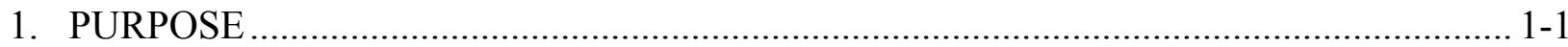

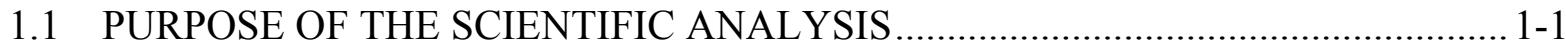

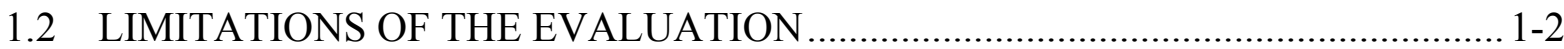

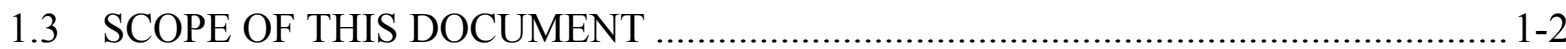

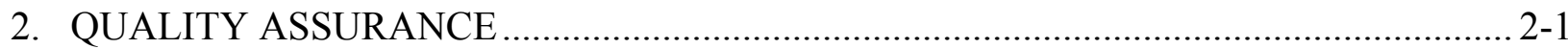

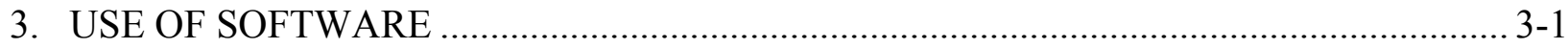

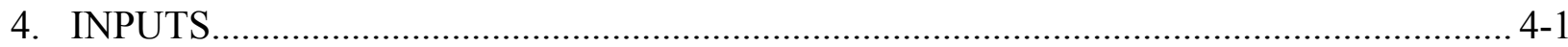

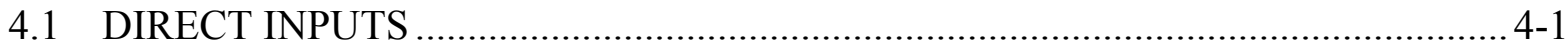

4.1.1 Direct Inputs from Project Sources .................................................................... 4-1

4.1.2 Direct Inputs from Outside Sources................................................................ 4-2

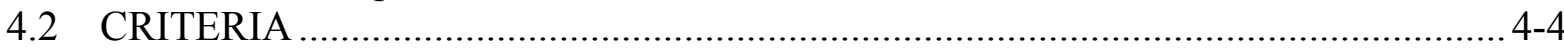

4.2.1 Yucca Mountain Review Plan Criteria ....................................................... 4-4

4.2.2 Required Documentation of Level of Accuracy ............................................. 4-9

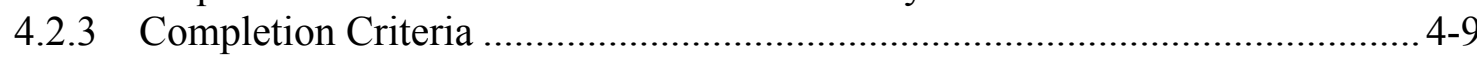

4.3 CODES, STANDARDS, AND REGULATIONS ............................................. 4-10

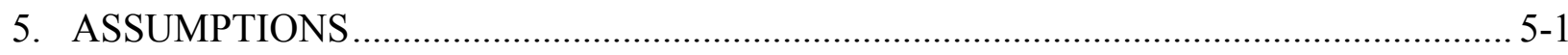

6. SCIENTIFIC ANALYSIS AND DISCUSSION ………....................................................

6.1 SYSTEMATICS OF REPOSITORY BIOGEOCHEMISTRY .............................. 6-1

6.1.1 Heterotrophs Versus Autotrophs........................................................... 6-1

6.1.2 Microbially Mediated Redox Processes........................................................... 6-3

6.1.3 Relevant Biogeochemical Processes......................................................... 6-4

6.1.4 Status of Repository-Related Microbiological Studies .................................... 6-8

6.2 FEATURES, EVENTS, AND PROCESSES ADDRESSED BY THIS ANALYSIS ............................................................................................... 6-11

6.3 CHARACTERIZATION OF THE MICROBIAL POPULATION AT YMP............ 6-12

6.4 ENVIRONMENTAL CONSTRAINTS ON MICROBIAL ACTIVITY AT

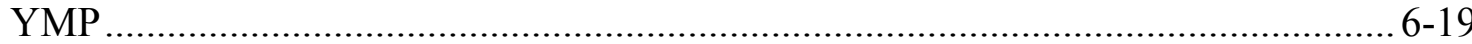

6.4.1 Temperature and Pressure Constraints....................................................... 6-19

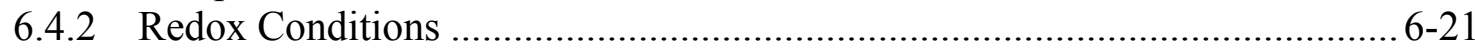

6.4.3 Relative Humidity and Water Availability ..................................................... 6-25

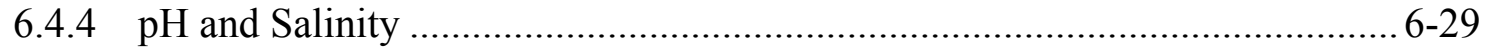

6.4.5 Inputs of Nutrients ............................................................................... 6-29

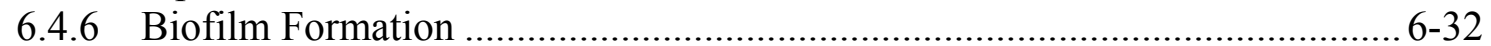

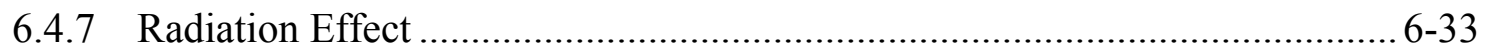

6.5 POTENTIAL IMPACTS ON REPOSITORY CHEMISTRY ................................. 6-36

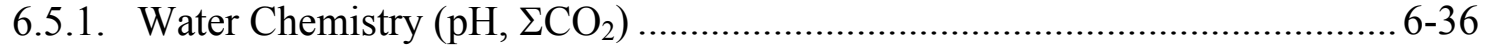

6.5.2 Low Molecular-Weight Organic Ligands ...................................................... 6-38 


\section{CONTENTS (Continued)}

Page

6.5.3 Biotransformation and Biosorption of Radionuclides ................................. 6-40

6.5.4 Colloid-Facilitated Transport........................................................................ 6-43

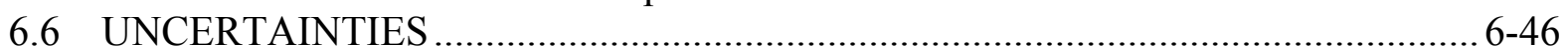

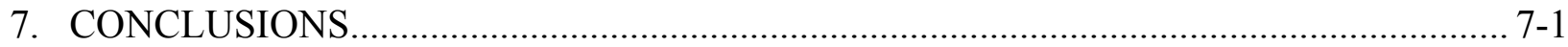

7.1 EVALUATION CONCLUSIONS................................................................ $7-1$

7.2 YUCCA MOUNTAIN REVIEW PLAN CRITERIA ASSESSMENT ...................... 7-3

7.3 REQUIRED DOCUMENTATION OF LEVEL OF ACCURACY …..................... 7-10

7.4 COMPLETION CRITERIA …...................................................................... 7-10

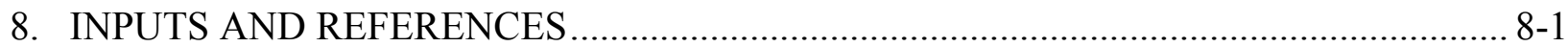

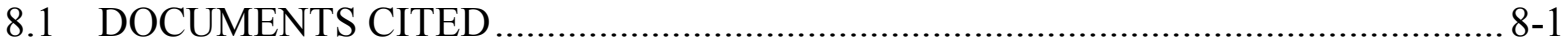

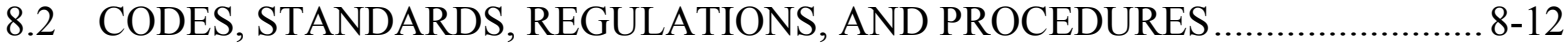

8.3 SOURCE DATA, LISTED BY DATA TRACKING NUMBER ........................... 8-12 


\section{FIGURES}

Page

6.1-1. Systematics of Repository Biogeochemistry

6-5

6.1-2. Microbial Transformations of Radionuclides and Metals in Wastes

6.3-1. Frequency of Unique Clone Types in Yucca Mountain Rock (of 200 Screened)

6.3-2. Phylogenetic Tree of Yucca Mountain Microbial Community

6.4-1. TH Simulation (Tptpll): Time Profiles of Modeled Temperatures in Fractures (Similar in Matrix) at Three Drift-Wall Locations and in the Waste Package

6.4-2. Temporal Evolution of Air Mass Fractions in the Gas Phase in Fractures and Matrix at Three Drift-Wall Locations

6.4-3. Frequency of Unique Clone Types in a Long-Term Corrosion Tests Tank Containing Simulated 10X Groundwater at $60^{\circ} \mathrm{C}$

6.4-4. Growth Rates of Yucca Mountain Aerobic Bacteria in Unconcentrated Groundwater (1xJ13 Synthetic Medium) with and without Glucose Added.

6.4-5. Range of Relative Humidity Histories for All Waste Packages, Accounting for Uncertainty of Host-Rock Thermal Conductivity and Percolation Flux

6.4-6. TH Simulation (Tptpll): Time Profiles of Modeled Liquid Saturations in Fractures at Three Drift-Wall Locations

6.4-7. Growth of Yucca Mountain Culturable Aerobic Bacteria as a Function of Macronutrient Concentration in Yucca Mountain

6.5-1. $\mathrm{CO}_{2}$ Flux Calculated from a Cumulative Gas Flux Predicted by the THC Model 6-38 


\section{INTENTIONALLY LEFT BLANK}




\section{TABLES}

Page

4.1-1. Direct Inputs from Project Sources........................................................................... 4-1

4.1-2. Numeric Data from Outside Sources Used as Direct Inputs..................................... 4-2

4.1-3. Information from Outside Sources, Other Than Data, Used as Direct Inputs ................ 4-2

4.1-4 Qualification of Data for Its Intended Use (as Direct Input) for This Analysis ............. 4-3

6.1-1. Nutritional Requirements of Microorganisms ...................................................... 6-2

6.1-2. Representative Heterotrophic Metabolic Pathways ................................................. 6-4

6.1-3. Abundance of Microorganisms in Plutonium-Contaminated Soils and Radioactive

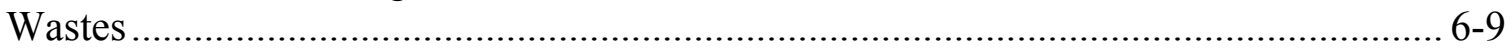

6.1-4. Bacteria Detected in Radioactive Waste Repository Environments ........................... 6-10

6.1-5. Number of Bacteria at Natural Analogue Sites........................................................ 6-10

6.1-6. Microbial Population in Backfill Materials Proposed for Use at the Radioactive Waste Repositories....................................................................................... 6-11

6.2-1. FEPs Included in the TSPA-LA and Addressed by This Document ........................... 6-11

6.2-2. FEPs Excluded in the TSPA-LA and Addressed by This Document ......................... 6-11

6.3-1. Organisms Isolated After Growth in Various Yucca Mountain Simulated Groundwaters and 16S rDNA Sequence Divergence from Reference Organisms........ 6-14

6.4-1. Temperature Range for Microbial Growth. ........................................................... 6-19

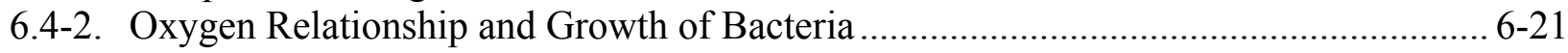

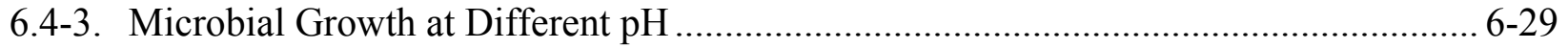

6.4-4. Radioresistance of Soil Microorganisms Previously Exposed to Long-Term $\gamma$-Irradiation (Expressed as a Percentage of Tubes with Visible Growth).................... 6-34

6.4-5. Gamma Radiation Resistance of Bacteria Isolated from Various Sources................... 6-34

6.5-1. Microbial Production of Low-MW Organic Acids Detected in the WIPP

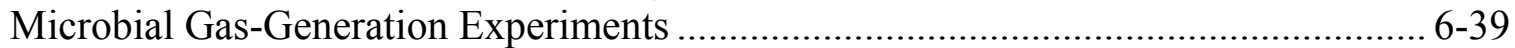

6.5-2. Complexation of $\mathrm{Am}^{3+}$ with Intermediate Metabolites ........................................... 6-40

6.5-3. Summary of Biotransformation of Actinides and Its Relevance to the YMP.............. 6-43 


\section{INTENTIONALLY LEFT BLANK}




\section{ACRONYMS AND ABBREVIATIONS}

AECL Atomic Energy of Canada Limited

CFU colony-forming unit

DOE U.S. Department of Energy

DTN data tracking number

EPS extracellular polymeric substances

ESF Exploratory Studies Facility

EXAFS extended X-ray absorption fine structure

FEP feature, event, and process

HPC heterotrophic plate count

IED information exchange drawing

LA license application

MIC microbially influenced corrosion

MW molecular weight

NIST National Institute of Standards and Technology

PLFA phospholipid fatty acids

RDP Ribosomal Database Project

SEM scanning electron microscope

TDMS Technical Data Management System

THC thermal-hydrological-chemical

TSPA total system performance assessment

TWP technical work plan

UZ unsaturated zone

VBNC viable but not culturable

WIPP Waste Isolation Pilot Plant

YMP Yucca Mountain Project 


\section{INTENTIONALLY LEFT BLANK}




\section{PURPOSE}

\subsection{PURPOSE OF THE SCIENTIFIC ANALYSIS}

Evaluation of Potential Impacts of Microbial Activity on Drift Chemistry focuses on the potential for microbial communities that could be active in repository emplacement drifts to influence the in-drift bulk chemical environment. This report feeds analyses to support the inclusion or exclusion of features, events, and processes (FEPs) in the total system performance assessment (TSPA) for the license application (LA), but this work is not expected to generate direct feeds to the TSPA-LA. The purpose was specified by, and the evaluation was performed and is documented in accordance with, Technical Work Plan For: Near-Field Environment and Transport In-Drift Geochemistry Analyses (BSC 2004 [DIRS 172402], Section 2.1). This report addresses all of the FEPs assigned by the technical work plan (TWP), including the development of exclusion arguments for FEPs that are not carried forward to the TSPA-LA. Except for an editorial correction noted in Section 6.2, there were no other deviations from the TWP.

This report documents the completion of all assigned tasks, as follows (BSC 2004 [DIRS 172402], Section 1.2.1):

- Perform analyses to evaluate the potential for microbial activity in the waste emplacement drift under the constraints of anticipated physical and chemical conditions.

- Evaluate uncertainties associated with these analyses.

- Determine whether the potential for microbes warrants a feed to TSPA-LA to account for predicted effects on repository performance.

- Provide information to address the Yucca Mountain Review Plan, Final Report (NUREG-1804) (NRC 2003 [DIRS 163274]) and Key Technical Issues and agreements, as appropriate.

- Develop information for inclusion or exclusion of FEPs.

The planned scientific approach specified the inclusion of the following activities (BSC 2004 [DIRS 172402], Section 2.2):

- Review of repository-related microbiological and biogeochemical studies, to establish a defensible technical framework for the evaluation of the impacts of microbial activity on long-term repository performance

- Review of Yucca Mountain site characterization data for microbial population distributions, and identification of potential limiting factors for the growth of Yucca Mountain bacteria

- Description of the physical and chemical repository environment, as documented in other Project documents 
- Systematic evaluation of the environmental constraints on microbial activity in actual repository environments

- Systematic evaluation of the impacts of microbial activity on waste drift chemistry.

\subsection{LIMITATIONS OF THE EVALUATION}

As provided by the TWP, the boundary conditions for this work are established in related process model documents, such as Multiscale Thermohydrologic Model (BSC 2004 [DIRS 169565]) and Engineered Barrier System: Physical and Chemical Environment (BSC 2004 [DIRS 169860]), and in applicable information exchange drawings (IEDs). This evaluation is limited to the drift environment established by those boundary conditions.

The general chemical environments within the repository and its adjacent regions will remain oxic (containing oxygen) over the regulatory period of 10,000 years. As discussed in Section 6.4 , the oxygen concentration in the waste drift could be depleted during a thermal event, when the air mass is pushed away from the drift by water vapor, but this depletion is transitional and will not affect microbial reaction pathways in the repository. Also, oxygen will be consumed by metal corrosion within the drift. This consumption is ignored in this evaluation.

\subsection{SCOPE OF THIS DOCUMENT}

AP-SIII.9Q, Scientific Analyses, establishes the responsibilities and the process for performing and documenting this scientific analysis. In accordance with the outline specified by that procedure, the first three sections of this report place the work in the context of the plans and requirements established by the U.S. Department of Energy Office of Civilian Radioactive Waste Management and by the Yucca Mountain Project (YMP). In particular, Sections 2 and 3 of this report identify the applicability of the quality assurance (QA) program to this analysis, including software QA.

Sections 4 and 5 present the essential information required for development of the conclusions found in Section 6 and summarized in Section 7. Section 4 documents the key inputs to the evaluation, including:

- Sources of information or data used to develop the conclusions (direct inputs)

- The acceptance and completion criteria, including the applicable criteria from NUREG-1804

- The required documentation level of accuracy

- The applicable codes, standards, and regulations.

This report does not address any key technical issues.

Section 6 evaluates the potential of microbial activity in the waste emplacement drift under the constraints of anticipated physical and chemical conditions, beginning with three sections that provide background. 
Section 6.1 reviews repository-related microbiological and biogeochemical studies to establish the framework for the evaluation of the impacts of microbial activity on long-term repository performance.

Section 6.2 lists the included and excluded FEPs addressed in this analysis.

Section 6.3 reviews Yucca Mountain site characterization data for microbial population distributions, and identifies potential limiting factors for the growth of bacteria in the repository.

Section 6.4 describes the physical and chemical repository environment as documented in other YMP documents, and systematically evaluates the environmental constraints on microbial activity, leading to the conclusion that the high early temperatures, the oxic environment, the high-radiation field, and a scarcity of water and organic carbon will combine to limit microbial activity in the repository drifts.

Section 6.5 systematically evaluates the potential impacts on repository chemistry, given limited microbial activity.

Section 6.6 points out that the qualitative arguments and bounding calculations used in the evaluation fully capture uncertainties associated with the inputs.

Section 7 summarizes the evaluation, and consists of conclusions, the recommendation regarding a feed to TSPA-LA, and satisfaction of the criteria listed in Section 4. 
INTENTIONALLY LEFT BLANK 


\section{QUALITY ASSURANCE}

As stated in the TWP (BSC 2004 [DIRS 172402], Section 8.1), this report is subject to Quality Assurance Requirements and Description (DOE 2004 [DIRS 171539]). This analysis evaluates the effects of microbial activity on the environment in the engineered barrier system (EBS), which carries the Safety Category (SC) classification, as documented in Q-List (BSC 2004 [DIRS 168361], Table A-2).

Approved quality assurance procedures identified in the TWP (BSC 2004 [DIRS 172402], Section 4) have been used to conduct and document the activities described in this report. Specifically, this report has been prepared in accordance with AP-SIII.9Q, Scientific Analyses, and reviewed in accordance with AP-2.14Q, Document Review. All input data are identified and tracked in accordance with AP-3.15Q, Managing Technical Product Inputs.

As required by the TWP (BSC 2004 [DIRS 172402], Section 8.4), electronic data were managed and controlled in accordance with AP-SV.1Q, Control of the Electronic Management of Information. To ensure accuracy and completeness of the information generated by the activities described in the TWP, access to information on the computer workstations used by all staff was controlled with password protection. Access privileges were set to prevent unauthorized changes to files housed on network servers. In addition, the servers were periodically backed up and the backups labeled and stored. All electronic files used in this activity were stored and backed up on network servers. There were no variances from these methods for controlling the electronic management of data. 


\section{INTENTIONALLY LEFT BLANK}




\section{USE OF SOFTWARE}

This report did not use any software described as controlled and baselined in LP-S1.11Q-BSC, Software Management. No solutions were obtained through the use of a commercial off-the-shelf software program. 


\section{INTENTIONALLY LEFT BLANK}




\section{INPUTS}

\subsection{DIRECT INPUTS}

This section documents and substantiates the direct inputs used in this report (i.e., those data and other information items that were used to develop the results or conclusions). Because the conclusions are based on environmental factors that can severely limit microbial activity in the repository, only the inputs related to the limiting environmental factors are direct inputs.

\subsubsection{Direct Inputs from Project Sources}

Table 4.1-1 lists direct inputs from the following Project sources:

- Project data identified by data tracking number (DTN)

- IEDs

- Analysis and model reports that support the TSPA-LA.

None of the Project sources is a product output from a canceled/superseded document.

Table 4.1-1. Direct Inputs from Project Sources

\begin{tabular}{|c|c|c|}
\hline Parameter(s) or Information & Value(s) & Source \\
\hline In-drift thermal history & See Figure 6.4-1 & BSC 2004 [DIRS 169856], Figure 6.5-3 \\
\hline Evolution of air mass fractions in drift & See Figure 6.4-2 & BSC 2004 [DIRS 169856], Figure 6.5-8 \\
\hline $\begin{array}{l}\text { Growth rates of Yucca Mountain } \\
\text { aerobic bacteria in unconcentrated } \\
\text { groundwater }\end{array}$ & See Figure 6.4-4 & DTN: LL040801512251.115 [DIRS 171476] \\
\hline $\begin{array}{l}\text { Range of relative humidity on all } \\
\text { waste packages }\end{array}$ & See Figure 6.4-5 & BSC 2004 [DIRS 169565], Figure. 6.3-68 \\
\hline $\begin{array}{l}\text { Liquid saturations in fractures at } \\
\text { three drift-wall locations }\end{array}$ & See Figure 6.4-6 & BSC 2004 [DIRS 169856], Figure 6.5-6 \\
\hline $\begin{array}{l}\text { Growth rates of Yucca Mountain } \\
\text { culturable aerobic bacteria as a } \\
\text { function of macronutrient } \\
\text { concentration }\end{array}$ & See Figure 6.4-7 & DTN: LL040801512251.115 [DIRS 171476] \\
\hline $\begin{array}{l}\text { Largest concentration of organic } \\
\text { carbon in qualified analyses of } \\
\text { groundwater from locations in the } \\
\text { vicinity of Yucca Mountain }\end{array}$ & $1.1 \mathrm{mg} / \mathrm{L}$ & $\begin{array}{l}\text { DTN: GS011108312322.006 [DIRS 162911], } \\
\text { table name: S 01174_003, col. J }\end{array}$ \\
\hline $\mathrm{CO}_{2}$ flux & See Figure 6.5-1 & $\begin{array}{l}\text { DTN: SN0407T0510102.017 [DIRS 170667], } \\
\text { file: gas_flux.xIs, worksheet: Moles per m chart }\end{array}$ \\
\hline $\begin{array}{l}\text { Emplacement drift committed } \\
\text { materials have no organic } \\
\text { components }\end{array}$ & - & BSC 2004 [DIRS 170058] \\
\hline $\begin{array}{l}\text { A large quantity of } \mathrm{Fe}(\mathrm{III}) \text { may be } \\
\text { accumulated from oxic steel } \\
\text { corrosion }\end{array}$ & - & $\begin{array}{l}\text { BSC } 2004 \text { [DIRS 169868], Section } 5.6 \text { and } \\
\text { Table 6.3-4 }\end{array}$ \\
\hline
\end{tabular}


Table 4.1-1. Direct Inputs from Project Sources (Continued)

\begin{tabular}{|l|c|c|}
\hline \multicolumn{1}{|c|}{ Parameter(s) or Information } & Value(s) & \multicolumn{1}{c|}{ Source } \\
\hline $\begin{array}{l}\text { Under oxidizing conditions, } \mathrm{Pu} \text { will } \\
\text { be dominated by } \mathrm{Pu}(\mathrm{V}) \text { and } \mathrm{Pu}(\mathrm{VI}) \\
\text { instead of } \mathrm{Pu}(\mathrm{IV})\end{array}$ & - & BSC 2004 [DIRS 169425], Figure 6.5-5 \\
\hline Brine solutions ionic strength & $10 \mathrm{M}$ & BSC 2004 [DIRS 169860], Section 6.1.3 \\
\hline
\end{tabular}

\subsubsection{Direct Inputs from Outside Sources}

Table 4.1-2 lists the direct inputs (from outside sources) that were obtained from investigation activities such as measurement, testing, and analysis. Of these outside sources, the National Institute of Standards and Technology (NIST) maintains the database of reaction constants that is accepted by the scientific and engineering communities as established fact, and therefore the constants do not need to be qualified in accordance with YMP procedures. Data from the other two external sources listed in Table 4.1-2 and Table 4.1-3 are not established fact and are therefore demonstrated to be qualified for their intended use in Table 4.1-4 in accordance with Section 5.2.1.1 of AP-SIII.9Q.

Table 4.1-2. Numeric Data from Outside Sources Used as Direct Inputs

\begin{tabular}{|l|l|l|}
\hline \multicolumn{1}{|c|}{ Parameter(s) or Information } & \multicolumn{1}{|c|}{ Value(s) } & \multicolumn{1}{c|}{ Source } \\
\hline Upper temperature limit for microbial growth & $110^{\circ} \mathrm{C}$ & $\begin{array}{l}\text { Pedersen and Karlsson 1995 } \\
\text { [DIRS 100810] }\end{array}$ \\
\hline $\begin{array}{l}\text { Concentration of } \mathrm{O}_{2} \text { for aquatic sediments } \\
\text { above which anaerobic microbial reactions } \\
\text { are completely inhibited }\end{array}$ & $\begin{array}{l}1 \text { to } 30 \mu \mathrm{M} \text { (approximately 0.4 to } \\
10 \% \text { atmospheric oxygen) }\end{array}$ & $\begin{array}{l}\text { Wang and Van Cappellen 1996 } \\
\text { [DIRS 171057], Table 3 }\end{array}$ \\
\hline $\begin{array}{l}\text { Water activity levels at which bacteria can } \\
\text { grow }\end{array}$ & 0.75 to 1.00 & $\begin{array}{l}\text { Pedersen \& Karlsson 1995 } \\
\text { [DIRS 100810] }\end{array}$ \\
\hline Complexation constants & See Table 6.5-2 & NIST 2003 [DIRS 171201] \\
\hline Growth of Yucca Mountain bacteria & See Table 6.3-1 & Horn et al. 2004 [DIRS 171058] \\
\hline
\end{tabular}

Table 4.1-3. Information from Outside Sources, Other Than Data, Used as Direct Inputs

\begin{tabular}{|l|l|}
\hline \multicolumn{1}{|c|}{ Information } & \multicolumn{1}{c|}{ Source } \\
\hline Water is essential for microbial growth. & Horn et al. 2004 [DIRS 171058] \\
\hline $\begin{array}{l}\text { There is negligible long-distance biocolloid transport in porous } \\
\text { geologic media that are not significantly fractured. }\end{array}$ & DeFlaun et al. 1997 [DIRS 171060] \\
\hline Table 6.1-1 - Nutritional Requirements of Microorganisms & Pedersen and Karlsson 1995 [DIRS 100810] \\
\hline
\end{tabular}


Table 4.1-4. Qualification of Data for Its Intended Use (as Direct Input) for This Analysis

\begin{tabular}{|c|c|}
\hline Factors & Description \\
\hline \multicolumn{2}{|c|}{ Pedersen and Karlsson 1995 [DIRS 100810] } \\
\hline Description of use & $\begin{array}{l}\text { The study by Pedersen and Karlsson (1995 [DIRS 100810]) is used in Section } 6.4 .1 \text { as } \\
\text { a direct input for the maximum temperature at which known microorganisms can exist } \\
\text { in an active state. This source is also used in Section } 6.4 .3 \text { as a direct input for the } \\
\text { level of water activity at which bacteria grow well. }\end{array}$ \\
\hline $\begin{array}{l}\text { Extent to which the data } \\
\text { demonstrate the } \\
\text { properties of interest }\end{array}$ & $\begin{array}{l}\text { The study by Pedersen and Karlsson (1995 [DIRS 100810]) is a comprehensive } \\
\text { literature survey on the ranges of temperature and water activity that are conducive to } \\
\text { microbial activities. }\end{array}$ \\
\hline $\begin{array}{l}\text { Qualifications of personnel } \\
\text { or organizations } \\
\text { generating the data }\end{array}$ & $\begin{array}{l}\text { Professor Karsten Pedersen is director of the Deep Biosphere Laboratory at Göteborg } \\
\text { University, in Sweden. He has published more than } 50 \text { papers, reviews, and book } \\
\text { chapters in the peer-reviewed international scientific press, and he has written many } \\
\text { reports for international research agencies. He was engaged as an author and expert } \\
\text { in microbiology for the Swedish National Encyclopaedia between } 1990 \text { and } 2000 \text {, and } \\
\text { wrote more than } 150 \text { entries. He is serving on four international scientific journals. He } \\
\text { is on the editorial board of the Microbial Ecology and Geobiology journals, and is editor } \\
\text { for Europe for the scientific Geomicrobiology Journal. Professor Pedersen is also an } \\
\text { ad hoc reviewer for many different international scientific journals, including Nature } \\
\text { and Science, and for research agencies such as the U.S. National Science } \\
\text { Foundation. He was chairman of the European Science Foundation's scientific } \\
\text { program on groundwater pollution, GPoll, from } 1998 \text { to } 2001 \text {. }\end{array}$ \\
\hline Reliability of data source & $\begin{array}{l}\text { Geochimica et Cosmochimica Acta is a professional scientific research journal of } \\
\text { geochemistry and cosmochemistry. Articles are usually evaluated by three reviewers. }\end{array}$ \\
\hline $\begin{array}{l}\text { Availability of } \\
\text { corroborating data }\end{array}$ & The maximum temperature is corroborated by Horn and Mike (1995 [DIRS 100765]). \\
\hline \multicolumn{2}{|c|}{ Wang and Van Cappellen 1996 [DIRS 171057] } \\
\hline Description of use & $\begin{array}{l}\text { The study by Wang and Van Cappellen (1996 [DIRS 171057]) is used in Section 6.4.2 } \\
\text { as a direct input for a typical limiting } \mathrm{O}_{2} \text { concentration, above which anaerobic } \\
\text { microbial reactions are inhibited. }\end{array}$ \\
\hline $\begin{array}{l}\text { Extent to which the data } \\
\text { demonstrate the } \\
\text { properties of interest }\end{array}$ & $\begin{array}{l}\text { These data, combined with the predicted } \mathrm{O}_{2} \text { concentrations, demonstrate that } \\
\text { anaerobic microbial reactions are unlikely. }\end{array}$ \\
\hline $\begin{array}{l}\text { Qualifications of personnel } \\
\text { or organizations } \\
\text { generating the data }\end{array}$ & $\begin{array}{l}\text { Dr. Yifeng Wang, a geochemist at Sandia National Laboratories, is the originator of } \\
\text { this scientific analysis document. Philippe Van Cappellen is Professor of } \\
\text { Geochemistry at Utricht University, Holland. The work was performed at the School of } \\
\text { Earth and Atmospheric Sciences, Georgia Institute of Technology. }\end{array}$ \\
\hline Reliability of data source & $\begin{array}{l}\text { Geochimica et Cosmochimica Acta is a professional scientific research journal of } \\
\text { geochemistry and cosmochemistry. Articles are usually evaluated by three reviewers }\end{array}$ \\
\hline \multicolumn{2}{|c|}{ Horn et al. 2004 [DIRS 171058] } \\
\hline $\begin{array}{l}\text { Extent to which the input } \\
\text { demonstrates the } \\
\text { properties of interest }\end{array}$ & This input is a premise antecedent to a limitation on microbial growth. \\
\hline Description of use & $\begin{array}{l}\text { The study by Horn et al. (2004 [DIRS } 171058] \text { ) is used in Section } 6.3 \text {, Table } 6.3-1 \text {, and } \\
\text { Figure } 6.4-4 \text { as a direct input to demonstrate that water is essential for microbial } \\
\text { growth and for the growth rates of bacteria at Yucca Mountain. }\end{array}$ \\
\hline $\begin{array}{l}\text { Extent to which the data } \\
\text { demonstrate the } \\
\text { properties of interest }\end{array}$ & $\begin{array}{l}\text { Demonstrated growth rates and total number of bacteria present in Yucca Mountain } \\
\text { samples from the ESF. }\end{array}$ \\
\hline $\begin{array}{l}\text { Qualifications of personnel } \\
\text { or organizations } \\
\text { generating the data }\end{array}$ & $\begin{array}{l}\text { Dr. Joanne Horn is a microbiologist at Lawrence Livermore National Laboratories, and } \\
\text { is the originator of this scientific analysis document. }\end{array}$ \\
\hline
\end{tabular}


Table 4.1-4. Qualification of Data for Its Intended Use (as Direct Input) for This Analysis (Continued)

\begin{tabular}{|c|c|}
\hline Factors & Description \\
\hline \multicolumn{2}{|c|}{ Horn et al. 2004 [DIRS 171058] (Continued) } \\
\hline Reliability of data source & $\begin{array}{l}\text { Geomicrobiology Journal is a professional scientific research journal of } \\
\text { geomicrobiology. Articles are reviewed and evaluated by peers in the field of } \\
\text { geomicrobiology. }\end{array}$ \\
\hline $\begin{array}{l}\text { Availability of corroborating } \\
\text { input }\end{array}$ & $\begin{array}{l}\text { This input is corroborated by Amy (1997 [DIRS 100696]), Amy and Haldeman (1997 } \\
\text { [DIRS 100697]), and Madigan et al. (2003 [DIRS 171083]). }\end{array}$ \\
\hline \multicolumn{2}{|c|}{ DeFlaun et al. 1997 [DIRS 171060] } \\
\hline $\begin{array}{l}\text { Extent to which the input } \\
\text { demonstrates the } \\
\text { properties of interest }\end{array}$ & This input is direct support of a conclusion of this evaluation. \\
\hline Description of use & $\begin{array}{l}\text { The study by DeFlaun et al. (1997 [DIRS } 171060] \text { ) is used in Section } 6.5 .4 \text { as a direct } \\
\text { input to demonstrate that there is negligible long-distance biocolloid transport in } \\
\text { porous geologic media that is not significantly fractured. }\end{array}$ \\
\hline $\begin{array}{l}\text { Extent to which the data } \\
\text { demonstrate the properties } \\
\text { of interest }\end{array}$ & $\begin{array}{l}\text { Microbial transport testing conducted in a sandy aquifer on the coastal plain of Virginia } \\
\text { demonstrated that bacteria traveled the length of the flowfield, but was mostly retained } \\
\text { between the injection point and } 0.5-\mathrm{m} \text { sample area. }\end{array}$ \\
\hline Reliability of data source & $\begin{array}{l}\text { FEMS Microbiology Reviews is a professional scientific research journal of } \\
\text { microbiology. The journal articles are peer reviewed and independently edited by } \\
\text { acknowledged experts in their field of microbology. }\end{array}$ \\
\hline $\begin{array}{l}\text { Availability of corroborating } \\
\text { input }\end{array}$ & $\begin{array}{l}\text { This input is corroborated by Delany (1995 [DIRS 100134]) and Means (1982 } \\
\text { [DIRS 171136]). }\end{array}$ \\
\hline
\end{tabular}

\subsection{CRITERIA}

The TWP (BSC 2004 [DIRS 172402], Section 3) provides the applicable criteria from Yucca Mountain Review Plan, Final Report (NRC 2003 [DIRS 163274]), the required documentation of level of accuracy, and the source of completion criteria. Each criterion is detailed in Section 4.2.1.

\subsubsection{Yucca Mountain Review Plan Criteria}

The TWP (BSC 2004 [DIRS 172402], Section 3.2) applies to this evaluation with the acceptance criteria for the model abstraction, "Quantity and Chemistry of Water Contacting Engineered Barriers and Waste Forms." Yucca Mountain Review Plan, Final Report (NRC 2003 [DIRS 163274]) lists the following acceptance criteria for that model abstraction (NRC 2003 [DIRS 163274], Section 2.2.1.3.3.3):

- Acceptance Criterion 1 - System Description and Model Integration Are Adequate.

(1) Total system performance assessment adequately incorporates important design features, physical phenomena, and couplings, and uses consistent and appropriate assumptions throughout the quantity and chemistry of water contacting engineered barriers and waste forms abstraction process;

(2) The abstraction of the quantity and chemistry of water contacting engineered barriers and waste forms uses assumptions, technical bases, data, and models, that are appropriate and consistent with other related U.S. Department of Energy 
abstractions. For example, the assumptions used for the quantity and chemistry of water contacting engineered barriers and waste forms are consistent with the abstractions of "Degradation of Engineered Barriers" (Section 2.2.1.3.1); "Mechanical Disruption of Engineered Barriers (Section 2.2.1.3.2); "Radionuclide Release Rates and Solubility Limits" (Section 2.2.1.3.4); "Climate and Infiltration" (Section 2.2.1.3.5); and "Flow Paths in the Unsaturated Zone" (Section 2.2.1.3.6). The descriptions and technical bases provide transparent and traceable support for the abstraction of quantity and chemistry of water contacting engineered barriers and waste forms;

(3) Important design features, such as waste package design and material selection, backfill, drip shield, ground support, thermal loading strategy, and degradation processes, are adequate to determine the initial and boundary conditions for calculations of the quantity and chemistry of water contacting engineered barriers and waste forms;

(4) Spatial and temporal abstractions appropriately address physical couplings (thermal-hydrologic-mechanical-chemical). For example, the U.S. Department of Energy evaluates the potential for focusing of water flow into drifts, caused by coupled thermal-hydrologic-mechanical-chemical processes;

(5) Sufficient technical bases and justification are provided for total system performance assessment assumptions and approximations for modeling coupled thermal-hydrologic and mechanical-chemical effects on seepage and flow, the waste package chemical environment, and the chemical environment for radionuclide release. The effects of distribution of flow on the amount of water contacting the engineered barriers and waste forms are consistently addressed, in all relevant abstractions;

(6) The expected ranges of environmental conditions within the waste package emplacement drifts, inside of breached waste packages, and contacting the waste forms and their evolution with time are identified. These ranges may be developed to include:

(i) the effects of the drip shield and backfill on the quantity and chemistry of water (e.g., the potential for condensate formation and dripping from the underside of the shield);

(ii) conditions that promote corrosion of engineered barriers and degradation of waste forms;

(iii) irregular wet and dry cycles;

(iv) gamma-radiolysis; and

(v) size and distribution of penetrations of engineered barriers; 
(7) The model abstraction for quantity and chemistry of water contacting engineered barriers and waste forms is consistent with the detailed information on engineered barrier design and other engineered features. For example, consistency is demonstrated for:

(i) dimensionality of the abstractions;

(ii) various design features and site characteristics; and

(iii) alternative conceptual approaches. Analyses are adequate to demonstrate that no deleterious effects are caused by design or site features that the U.S. Department of Energy does not take into account in this abstraction;

(8) Adequate technical bases are provided, including activities such as independent modeling, laboratory or field data, or sensitivity studies, for inclusion of any thermal-hydrologic-mechanical-chemical couplings and features, events, and processes; and

(9) Performance-affecting processes that have been observed in thermal-hydrologic tests and experiments are included into the performance assessment. For example, the U.S. Department of Energy either demonstrates that liquid water will not reflux into the underground facility or incorporates refluxing water into the performance assessment calculation, and bounds the potential adverse effects of alteration of the hydraulic pathway that result from refluxing water.

(10) Likely modes for container corrosion are identified and considered in determining the quantity and chemistry of water entering the engineered barriers and contacting waste forms. For example, the model abstractions consistently address the role of parameters, such as $\mathrm{pH}$, carbonate concentration, and the effect of corrosion on the quantity and chemistry of water contacting engineered barriers and waste forms;

(11) The abstraction of in-package criticality or external-to-package criticality, within the emplacement drift, provides an adequate technical basis for screening these events;

(12) Guidance in NUREG-1297 [DIRS 103597] and NUREG-1298 [DIRS 103750] or other acceptable approaches, is followed.

- Acceptance Criterion 2 - Data Are Sufficient for Model Justification.

(1) Geological, hydrological, and geochemical values used in the license application are adequately justified. Adequate description of how the data were used, interpreted, and appropriately synthesized into the parameters is provided;

(2) Sufficient data were collected on the characteristics of the natural system and engineered materials to establish initial and boundary conditions for conceptual models of thermal-hydrologic-mechanical-chemical coupled processes, that affect seepage and flow and the engineered barrier chemical environment. 
(3) Thermo-hydrologic tests were designed and conducted with the explicit objectives of observing thermal-hydrologic processes for the temperature ranges expected for repository conditions and making measurements for mathematical models. Data are sufficient to verify that thermal-hydrologic conceptual models address important thermal-hydrologic phenomena;

(4) Sufficient information to formulate the conceptual approach(es) for analyzing water contact with the drip shield, engineered barriers, and waste forms is provided; and

(5) Sufficient data are provided to complete a nutrient- and energy-inventory calculation, if it has been used to justify the inclusion of the potential for microbial activity affecting the engineered barrier chemical environment and the chemical environment for radionuclide release. As necessary, data are adequate to support determination of the probability for microbially influenced corrosion (MIC) and microbial effects, such as production of organic byproducts and microbially enhanced dissolution of the high-level radioactive waste glass form.

- Acceptance Criterion 3 - Data Uncertainty Is Characterized and Propagated Through the Model Abstraction.

(1) Models use parameter values, assumed ranges, probability distributions, and bounding assumptions that are technically defensible, reasonably account for uncertainties and variabilities, and do not result in an under-representation of the risk estimate;

(2) Parameter values, assumed ranges, probability distributions, and bounding assumptions used in the total system performance assessment calculations of quantity and chemistry of water contacting engineered barriers and waste forms are technically defensible and reasonable, based on data from the Yucca Mountain region (e.g., results from large block and drift-scale heater and niche tests), and a combination of techniques that may include laboratory experiments, field measurements, natural analog research, and process-level modeling studies;

(3) Input values used in the total system performance assessment calculations of quantity and chemistry of water contacting engineered barriers (e.g., drip shield and waste package) are consistent with the initial and boundary conditions and the assumptions of the conceptual models and design concepts for the Yucca Mountain site. Correlations between input values are appropriately established in the U.S. Department of Energy total system performance assessment. Parameters used to define initial conditions, boundary conditions, and computational domain in sensitivity analyses involving coupled thermal-hydrologic-mechanical-chemical effects on seepage and flow, the waste package chemical environment, and the chemical environment for radionuclide release, are consistent with available data. Reasonable or conservative ranges of parameters or functional relations are established; 
(4) Adequate representation of uncertainties in the characteristics of the natural system and engineered materials is provided in parameter development for conceptual models, process-level models, and alternative conceptual models. The U.S. Department of Energy may constrain these uncertainties using sensitivity analyses or conservative limits. For example, the U.S. Department of Energy demonstrates how parameters used to describe flow through the engineered barrier system bound the effects of backfill and excavation-induced changes;

(5) If criticality is included in the total system performance assessment, the U.S. Department of Energy uses an appropriate range of input parameters for calculating the effective neutron multiplication factor; and

(6) Where sufficient data do not exist, the definition of parameter values and conceptual models is based on other appropriate sources, such as expert elicitation conducted in accordance with NUREG-1563 [DIRS 100909].

- Acceptance Criterion 4 - Model Uncertainty Is Characterized and Propagated Through the Model Abstraction.

(1) Alternative modeling approaches of features, events, and processes are considered and are consistent with available data and current scientific understanding, and the results and limitations are appropriately considered in the abstraction;

(2) Alternative modeling approaches are considered and the selected modeling approach is consistent with available data and current scientific understanding. A description that includes a discussion of alternative modeling approaches not considered in the final analysis and the limitations and uncertainties of the chosen model is provided;

(3) Consideration of conceptual model uncertainty is consistent with available site characterization data, laboratory experiments, field measurements, natural analog information and process-level modeling studies; and the treatment of conceptual model uncertainty does not result in an under-representation of the risk estimate;

(4) Adequate consideration is given to effects of thermal-hydrologic-mechanicalchemical coupled processes in the assessment of alternative conceptual models. These effects may include:

(i) thermal-hydrologic effects on gas, water, and mineral chemistry;

(ii) effects of microbial processes on the engineered barrier chemical environment and the chemical environment for radionuclide release;

(iii) changes in water chemistry that may result from the release of corrosion products from the engineered barriers and interactions between engineered materials and ground water; and 
(iv) changes in boundary conditions (e.g., drift shape and size) and hydrologic properties, relating to the response of the geomechanical system to thermal loading; and

(5) If the U.S. Department of Energy uses an equivalent continuum model for the total system performance assessment abstraction, the models produce conservative estimates of the effects of coupled thermal-hydrologic-mechanical-chemical processes on calculated compliance with the postclosure public health and environmental standards.

- Acceptance Criterion 5 - Model Abstraction Output Is Supported by Objective Comparisons.

(1) The models implemented in this total system performance assessment abstraction provide results consistent with output from detailed process-level models and/or empirical observations (laboratory and field tests and/or natural analogs);

(2) Abstracted models for coupled thermal-hydrologic-mechanical-chemical effects on seepage and flow and the engineered barrier chemical environment, as well as on the chemical environment for radionuclide release, are based on the same assumptions and approximations demonstrated to be appropriate for process-level models or closely analogous natural or experimental systems. For example, abstractions of processes, such as thermally induced changes in hydrological properties, or estimated diversion of percolation away from the drifts, are adequately justified by comparison to results of process-level modeling, that are consistent with direct observations and field studies; and

(3) Accepted and well-documented procedures are used to construct and test the numerical models that simulate coupled thermal-hydrologic-mechanical-chemical effects on seepage and flow, engineered barrier chemical environment, and the chemical environment for radionuclide release. Analytical and numerical models are appropriately supported. Abstracted model results are compared with different mathematical models, to judge robustness of results.

\subsubsection{Required Documentation of Level of Accuracy}

The TWP (BSC 2004 [DIRS 172402], Section 3.3) requires this report to state the level of accuracy, precision, and representativeness of the results of the analyses, and to state how each of these were determined.

\subsubsection{Completion Criteria}

The TWP (BSC 2004 [DIRS 172402], Section 3.4) requires the work that is done to be consistent with the activities performed as part of Technical Work Plan: Regulatory Integration Evaluation of Analysis and Model Reports Supporting the TSPA-LA (BSC 2004 [DIRS 169653]), and that it fulfill the portion of the Phase 2 work identified in that plan. That is, the work should address the prioritized list of actions selected in Phase 1 for disposition in Phase 2 (BSC 2004 [DIRS 169653], Section 1.3). 


\subsection{CODES, STANDARDS, AND REGULATIONS}

This report was prepared in accordance with 10 CFR Part 63 [DIRS 156605]. Relevant requirements for performance assessment from Section 114 of that document are:

Any performance assessment used to demonstrate compliance with Sec. 113(b) shall:

(a) Include data related to the geology, hydrology, and geochemistry... used to define parameters and conceptual models used in the assessment.

(b) Account for uncertainties and variabilities in parameter values and provide the technical basis for parameter ranges, probability distributions, or bounding values used in the performance assessment....

(g) Provide the technical basis for models used in the performance assessment such as comparisons made with outputs of detailed process-level models....

The source of complexation constants used in this evaluation is the NIST database of reaction constants. No other codes, standards, or regulations were used in the scientific analysis documented in this report. 


\section{ASSUMPTIONS}

The analyses in this report use the following assumptions:

- Organic substances such as diesel fuel, diesel exhaust, lubricants, rock drill oil, coolants, and cleaning solvents may be introduced into the repository during construction and operations. The quantities and types of such substances will be controlled, with analysis of the potential impacts to waste isolation (BSC 2004 [DIRS 169885], Section 6.12.3); LP-SA-001Q-BSC, Determination of Importance and Site Performance Protection Evaluations). It is assumed that these control and analysis practices will continue during repository construction and operation, and that construction and operation activities will not contribute committed materials that cause microbial activity to significantly affect the in-drift chemical environment.

- The concentrations of organic carbon in groundwater at Yucca Mountain will remain at a current level $(<1.1 \mathrm{mg} / \mathrm{L})$ over the whole regulatory time period. Most groundwaters that are not affected by pollution have dissolved organic carbon concentrations below $2 \mathrm{mg} / \mathrm{L}$ (Drever 1997 [DIRS 140067], p. 118). Thus, even if future climatic changes may take place at Yucca Mountian site, the organic carbon concentrations in groundwaters are expected to be still less than $2 \mathrm{mg} / \mathrm{L}$. Such small changes will not affect the conclusion about nutrient limitations in this document. 


\section{INTENTIONALLY LEFT BLANK}




\section{SCIENTIFIC ANALYSIS AND DISCUSSION}

This section evaluates the potential of microbial activity in the drift, under the constraints of anticipated physical and chemical conditions. The first three sections provide background. Section 6.1 reviews microbiological and biogeochemical studies for repositories, including Yucca Mountain. Section 6.2 lists the FEPs addressed in the analyses. Section 6.3 reviews Yucca Mountain site characterization data for microbial population distributions, and identifies potential limiting factors for the growth of Yucca Mountain bacteria.

The conclusions of the evaluation are based on Section 6.4 and Section 6.5. Section 6.4 describes the physical and chemical repository environment as documented in other YMP products and systematically evaluates the environmental constraints on microbial activities.

Section 6.5 systematically evaluates the potential impacts on repository chemistry, given the limitations of microbial activity. Section 6.5.1 concludes that the effects on water chemistry are negligible. Although microorganisms may release chemicals that complex with radionuclides, Section 6.5.2 concludes that either the concentrations of complexing agents are low, or their binding sites will be dominated by iron ions, or both. Section 6.5 .3 concludes that potential effects on radionuclide solubility can be conservatively ignored. Section 6.5.4 examines the potential for biocolloid-facilitated transport; it concludes that the concentration of suspended microbial cells is low compared to that of groundwater colloid particles and a separate consideration of biocolloid-facilitated transport is not necessary. Section 6.6 notes that uncertainties in the input parameters are fully captured by qualitative arguments and bounding calculations.

\subsection{SYSTEMATICS OF REPOSITORY BIOGEOCHEMISTRY}

Microbes are ubiquitous in the subsurface environment, and play a major role in the biogeochemical cycling of various elements. Of particular concern is the microbial impact on radioactive wastes disposed of within deep geological formations. Under appropriate conditions, various microbial processes can operate, and will potentially affect the mobility of radionuclides and the integrity of the engineered barrier system (EBS) of the repository. In this section, the general concepts of subsurface biogeochemistry related to nuclear waste disposal in a deep geologic formation are reviewed, and the relevant processes are identified.

\subsubsection{Heterotrophs Versus Autotrophs}

Depending on the availability of nutrients, electron donors, and electron acceptors, as well as other environmental factors, various microbial processes with diverse metabolic activity can be stimulated (Chapelle 2001 [DIRS 171162], Chapter 4). The environmental factors that can potentially affect microbial growth and activity include moisture, temperature, $\mathrm{pH}$, Eh, availability of organic and inorganic nutrients, and radiation. Microbes are exceedingly adaptable, and they are successful in colonizing a new environment. In fact, the environment provides the conditions necessary for the selection and adaptation of the organisms. The metabolic pathway that a given microorganism will use depends on the energy source (light or chemical); thus, a microorganism is described as either a phototroph or chemotroph, respectively. In a deep geologic repository, the activity of phototrophs can be excluded because 
of the lack of a light source after closure. On the basis of the environmental conditions and nutrient availability, the types of organisms that can exist in the Yucca Mountain repository environment should primarily follow the chemotrophic metabolic pathway.

If a chemotroph uses organic carbon as its source of carbon, it is referred to as a heterotroph; if it derives energy from the oxidation of inorganic compounds and derives cell carbon from $\mathrm{CO}_{2}$, it is called an autotroph. Table 6.1-1 shows the nutritional requirements of microorganisms. Because of their different nutritional requirements, the activities of these two groups of microorganisms in a deep geologic repository are limited in different ways, depending on the ambient chemical environment and the type of wastes to be emplaced in the repository.

Table 6.1-1. Nutritional Requirements of Microorganisms

\begin{tabular}{|l|l|l|l|}
\hline \multicolumn{1}{|c|}{ Type } & Carbon Source & \multicolumn{1}{|c|}{ Electron Source or Sink } & \multicolumn{1}{c|}{ Example of Organisms } \\
\hline Autotrophic & $\mathrm{CO}_{2}$ & $\begin{array}{l}\mathrm{H}_{2}, \mathrm{NH}_{4}{ }^{+}, \mathrm{NO}_{2}{ }^{-}, \mathrm{Mn}^{2+}, \\
\mathrm{Fe}^{2+}, \mathrm{H}_{2} \mathrm{~S}, \mathrm{~S}\end{array}$ & $\begin{array}{l}\text { Ammonium, nitrite, manganese } \\
\text { iron, sulfur, and hydrogen- } \\
\text { oxidizing bacteria; methanogenic } \\
\text { bacteria }\end{array}$ \\
\hline Heterotrophic & $\begin{array}{l}\text { Organic } \\
\text { compounds }\end{array}$ & $\begin{array}{l}\mathrm{O}_{2}, \mathrm{NO}_{3}{ }^{-}, \mathrm{MnO}_{2}, \mathrm{Fe}(\mathrm{OH})_{3}, \\
\mathrm{SO}_{4}{ }^{2-}, \text { organic compounds }\end{array}$ & Most bacteria \\
\hline
\end{tabular}

Source: Pedersen and Karlsson 1995 [DIRS 100810].

Autotrophs obtain their energy by the oxidation of inorganic compounds or ions, and acquire from $\mathrm{CO}_{2}$ the carbon necessary for cell synthesis. A typical pathway of autotrophic metabolism is the $\mathrm{H}_{2}$-based methanogenesis, which can be described by the following overall reaction:

$$
4 \mathrm{H}_{2}+\mathrm{CO}_{2} \rightarrow \mathrm{CH}_{4}+2 \mathrm{H}_{2} \mathrm{O}
$$

An autotrophic reaction is generally limited by the availability of inorganic electron donors such as $\mathrm{H}_{2}$ in Equation 6-1. To support cellular growth, autotrophs fix $\mathrm{CO}_{2}$ through a "Calvin cycle" (Chapelle 2001 [DIRS 171162], p. 111). The Calvin cycle begins with the reaction of $\mathrm{CO}_{2}$ with ribulose 1,5-diphosphate (RuDP) to form a six-carbon compound, which is then split into two molecules of 3-phosphoglycerate (PGA). Both PGA molecules are then reduced by nicotinamide adenine dinucleotide phosphate (NADPH). Next, a molecule of RuDP is regenerated, and the cycle repeats. Three turns of the cycles are necessary for the production of one molecule of glyceraldehydes-3-phosphate. A total of 12 NADPH and 18 ATP (adenosine triphosphate) are required to synthesize 1 hexose molecule. Therefore, the autotrophic fixation of $\mathrm{CO}_{2}$ requires a considerable investment of energy (Chapelle 2001 [DIRS 171162], p. 111). As a result, the direct utilization of $\mathrm{CO}_{2}$ by autotrophs in subsurface systems is probably slow. In contrast, heterotrophs show a great range of flexibility with respect to carbon sources. Some bacteria will degrade almost any reduced carbon source, whereas others will only catabolize a few carbon compounds. Heterotrophic metabolism dominates over autotrophic metabolism in many subsurface environments, even in some pristine environments where the organic carbon supply is relatively limited, since it is observed that carbonate species, which are the end products of heterotrophic metabolism, are accumulated in these natural systems (Chapelle 2001 [DIRS 171162]). 


\subsubsection{Microbially Mediated Redox Processes}

Microbial groups are known to use many redox pairs to derive their energy. If such chemical kinetic constraints exist that the rate of a given chemical reaction is sufficiently slow, bacteria can compete; thus, almost any redox pair that yields energy could be exploited. Microorganisms tend to accumulate at redox interfaces, where both metabolic electron donors and electron acceptors are available. Numerous studies have shown that microbial metabolism couples the inorganic redox chemistry of groundwaters to the oxidation of organic carbon (e.g., Lovley and Phillips 1988 [DIRS 171171]). As discussed in Section 6.1.1, heterotrophs derive their energy from the oxidative breakdown of external organic substrates; hence, microbial ecologies are frequently classified in terms of dominant pathways. The principal pathways are aerobic respiration, denitrification, manganese reduction, iron reduction, sulfate reduction, fermentation, and methanogenesis. From a biochemical point of view, the energy-yielding metabolic processes involve complex electron transfer chains. From a geochemical perspective, the significant reaction is the final electron transfer to an external electron acceptor. The common electron acceptors in subsurface environments are $\mathrm{O}_{2}, \mathrm{NO}_{3}{ }^{-}, \mathrm{MnO}_{2}, \mathrm{Fe}(\mathrm{OH})_{3}, \mathrm{SO}_{4}{ }^{2-}$, and $\mathrm{CO}_{2}$. Fermentation does not rely on an external electron acceptor; instead, it partially oxidizes and reduces an organic substrate. The final fermentation products include $\mathrm{CO}_{2}, \mathrm{H}_{2}$, alcohols, and organic acids (Table 6.1-2).

The primary pathways of organic carbon oxidation tend to occur in a predictable sequence (Table 6.1-2). The most energetically favorable is aerobic respiration, followed, in order of decreasing free energy yield, by denitrification, $\mathrm{Mn}(\mathrm{IV})$ reduction, $\mathrm{Fe}(\mathrm{III})$ reduction, sulfate reduction, and methanogenesis. The differences in the energy yields of these reactions, plus the availability of electron acceptors, lead to physical (spatial or temporal) separation of redox zones in which each pathway dominates. Because aerobic respiration is the most energetically favorable reaction, aerobic bacteria have a competitive advantage over anaerobic microorganisms when a certain level of $\mathrm{O}_{2}$ is present. This redox sequence is well established for natural systems including aquatic sediments (Wang and Van Cappellen 1996 [DIRS 171057]), groundwater systems (e.g., Chapelle 2001 [DIRS 171162]), and landfills (e.g., Baedecker et al. 1993 [DIRS 171125]). This sequence imposes an important constraint on metabolic processes that can occur in a specific repository environment.

The distribution of dissimilative pathways depends not only on their relative energy yields but also on the availability of organic carbon and electron acceptors. Hence, not all pathways necessarily occur within a given system. Most pristine subsurface systems, especially the UZs (such as those in Yucca Mountain), are oligotrophic (organic-poor) and, thus, generally remain aerobic. Within systems that have significant inputs of organic materials, $\mathrm{O}_{2}$ may become depleted, thereby allowing the emergence of anaerobic metabolic pathways.

Anaerobic degradation of organic compounds generates a variety of reduced species (e.g., $\mathrm{H}_{2}$, $\mathrm{NH}_{4}{ }^{+}, \mathrm{NO}_{2}{ }^{-}, \mathrm{Mn}^{2+}, \mathrm{Fe}^{2+}, \mathrm{H}_{2} \mathrm{~S}$, and $\mathrm{S}$ ) as metabolic products. Autotrophic bacteria can use these reduced species as their energy source. Thus, the anaerobic oxidation of organic compounds, coupled with the reduction of electron acceptors, could be the primary source of reduced inorganic substrates that are used for autotrophic metabolism. In such systems, both heterotrophic and autotrophic microbial activities are limited by the supply of organic carbon in the subsurface systems. Reduced inorganic species also can be derived from ferrous minerals in 
ambient rocks or from anoxic corrosion of waste package materials in a repository; the latter generates $\mathrm{H}_{2}$.

Table 6.1-2. Representative Heterotrophic Metabolic Pathways

\begin{tabular}{|ll|}
\hline \multicolumn{2}{|c|}{ Primary Pathways } \\
\hline Aerobic respiration: & $\mathrm{CH}_{2} \mathrm{O}+\mathrm{O}_{2}=\mathrm{CO}_{2}+\mathrm{H}_{2} \mathrm{O}$ \\
\hline Denitrification: & $\mathrm{CH}_{2} \mathrm{O}+4 / 5 \mathrm{NO}_{3}{ }^{-}+4 / 5 \mathrm{H}^{+}=2 / 5 \mathrm{~N}_{2}+\mathrm{CO}_{2}+7 / 5 \mathrm{H}_{2} \mathrm{O}$ \\
\hline Manganese reduction: & $\mathrm{CH}_{2} \mathrm{O}+2 \mathrm{MnO}_{2}+4 \mathrm{H}+=2 \mathrm{Mn}^{2+}+\mathrm{CO}_{2}+3 \mathrm{H}_{2} \mathrm{O}$ \\
\hline Iron reduction: & $\mathrm{CH}_{2} \mathrm{O}+4 \mathrm{FeOOH}+8 \mathrm{H}^{+}=4 \mathrm{Fe}^{2+}+\mathrm{CO}_{2}+7 \mathrm{H}_{2} \mathrm{O}$ \\
\hline Sulfate reduction: & $\mathrm{CH}_{2} \mathrm{O}+1 / 2 \mathrm{SO}_{4}{ }^{2-}+\mathrm{H}^{+}=1 / 2 \mathrm{H}_{2} \mathrm{~S}+\mathrm{CO}_{2}+\mathrm{H}_{2} \mathrm{O}$ \\
\hline Fermentation: & $6 \mathrm{CH}_{2} \mathrm{O}=\mathrm{CH}_{3} \mathrm{COOH}+\mathrm{CH}_{3} \mathrm{CH}_{2} \mathrm{COOH}+\mathrm{CO}_{2}+\mathrm{H}_{2}$ \\
\hline Methanogenesis: & $\mathrm{CH}_{2} \mathrm{O}=1 / 2 \mathrm{CH}_{4}+1 / 2 \mathrm{CO}_{2}$ \\
\hline
\end{tabular}

Source: Van Cappellen and Wang 1996 [DIRS 171128].

\subsubsection{Relevant Biogeochemical Processes}

The relative importance of various microbial processes in a specific repository greatly depends on the ambient environment of the repository, and the materials to be emplaced (Figure 6.1-1). A repository in unsaturated igneous rock formations (such as volcanic tuff rocks at Yucca Mountain) is generally expected to be oxidizing in its chemical environment; a repository in a hydrologically saturated zone, particularly in sedimentary rocks, could be reducing. Sedimentary rocks contain a certain amount of organic matter, which may stimulate significant microbial activities and, thus, maintain the repository and its surrounding areas in a reducing condition.

Both low-level and intermediate-level radioactive wastes contain a large portion of organic materials (e.g., cellulosics) and a significant amount of inorganic nutrients (e.g., $\mathrm{NO}_{3}{ }^{-}$). Microbial degradation of these materials has been a major concern for long-term repository performance assessment. An example is the Waste Isolation Pilot Plant (WIPP), which is located within a salt bed in Southern New Mexico and was designed for disposal of defense-related transuranic wastes. Microbial degradation of organic carbon-rich materials in the WIPP repository has been studied for its impact on repository pressurization and water chemistry (Francis et al. 1997 [DIRS 171062]; Wang et al. 1997 [DIRS 171122]). Unlike low-level and intermediate-level wastes, high-level radioactive wastes generally contain no organic materials, and are not conducive to microbial activity. In addition to the ambient rocks and the introduced materials, groundwater and gas flow may also provide inputs of organic compounds, electron acceptors (e.g., $\mathrm{O}_{2}$ and $\mathrm{NO}_{3}{ }^{-}$), and electron donors (e.g., $\mathrm{H}_{2}$ ), in addition to micronutrients.

As discussed in Section 6.1.1, based on the nutritional requirements, microorganisms in a repository can be classified into two groups: heterotrophs and autotrophs. The interplay of the two groups of microbes is shown in Figure 6.1-1. The overall activity of heterotrophs is limited by the supply of organic carbon; the relative importance of individual reaction pathways depends on the availability of electron acceptors. Similarly, autotrophs are limited by the supply of electron donors and inorganic carbon. Since carbon dioxide is present in most systems, the availability of reduced inorganic species (e.g., $\left.\mathrm{H}_{2}\right)$ is expected to be a major limiting factor for autotrophs. 


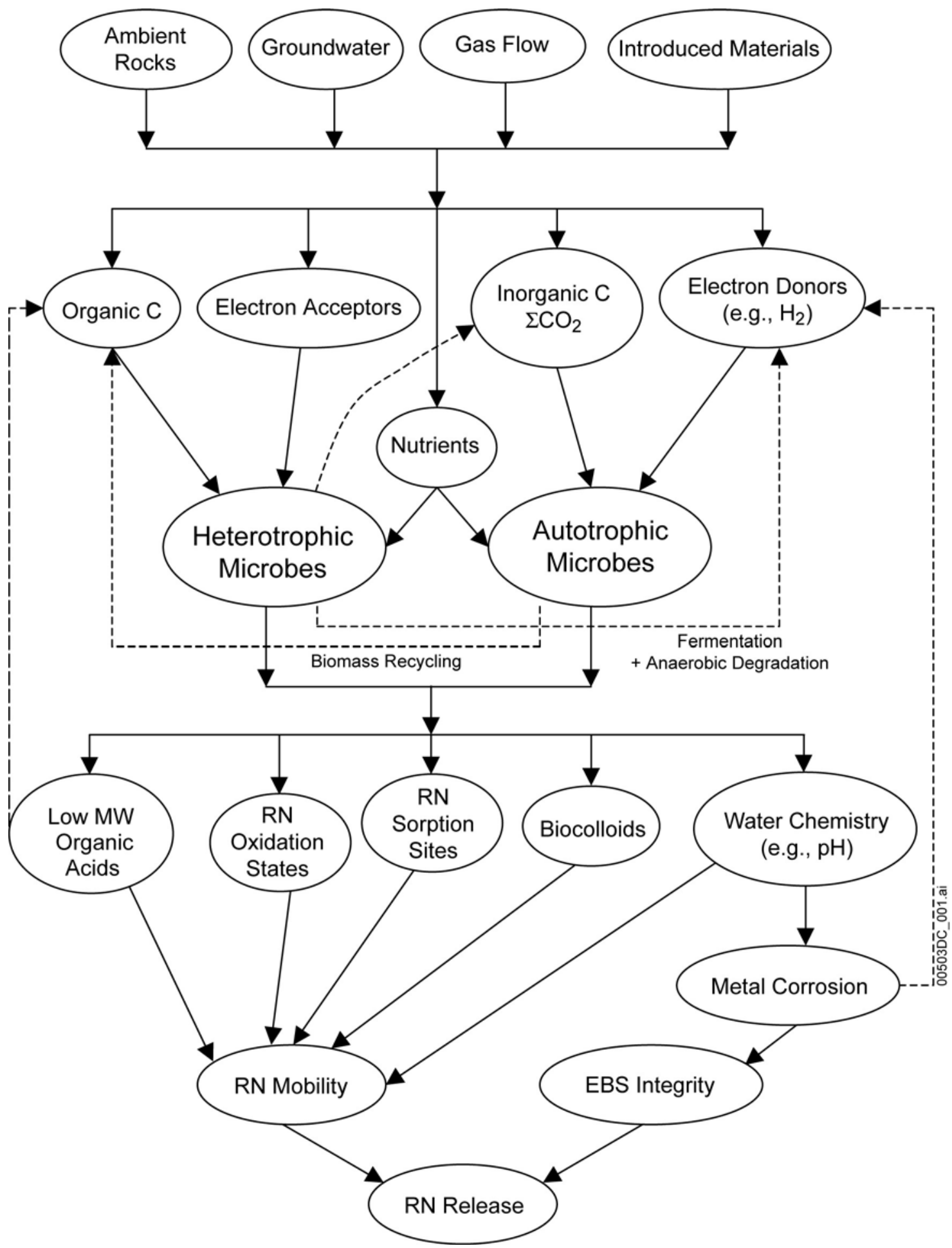

$\mathrm{MW}=$ Molecular weight; $\mathrm{RN}=$ Radionuclides.

Figure 6.1-1. Systematics of Repository Biogeochemistry 
In a nuclear-waste repository, the electron donors are derived from three sources:

- The anaerobic oxidation of organic compounds by heterotrophic bacteria can serve as the primary source of both the reduced inorganic substrates and the inorganic carbon for autotrophic metabolisms. For instance, fermentation produces $\mathrm{H}_{2}$ and $\mathrm{CO}_{2}$, both of which are needed by autotrophic methanogens for synthesizing methane.

- A large fraction of metals or metal alloys is always present in repositories, either as waste package materials or as other engineered components. Anoxic corrosion of these metals generates hydrogen gas:

$$
\mathrm{Fe}^{\circ}+2 \mathrm{H}_{2} \mathrm{O}=\mathrm{Fe}(\mathrm{OH})_{2}+\mathrm{H}_{2}
$$

- Reduced inorganic species may be brought in by groundwater or gas flows from the surrounding areas.

Sustainable autotrophic microbial activity requires the accumulation of a certain amount of reduced inorganic species in the repository, implying that a reducing environment is a prerequisite to possible autotrophic microbial activity within a geologic repository. As discussed further in subsequent sections, this requirement is not satisfied for the Yucca Mountain repository. Figure 6.1-1 illustrates the possibility that, through biomass recycling, a biomass synthesized by autotrophic bacteria can be used by heterotrophs.

The impacts of microbial activity on repository performance are several-fold (Wang and Papenguth 2001 [DIRS 171123]). The following impacts may affect radionuclide mobility in a specific repository environment:

- Microbes may be directly involved in redox reactions of multivalent radionuclides such as uranium and plutonium (Francis et al. 1991 [DIRS 171134]), whose solubilities highly depend on oxidation states.

- Microbial reactions may play an important role in regulating water chemistry (e.g., $\mathrm{pH}$, Eh, and $\left.\Sigma \mathrm{CO}_{2}\right)$ as well as secondary mineral distributions (i.e., radionuclide sorption sites).

- Microorganisms release low molecular weight (MW) organic acids including acetate, lactate, and formate, which are able to complex with radionuclides. On the other hand, biodegradation may eliminate organic ligands and reduce the mobility of radionuclides.

- Microbial cells may act as colloidal particles and thus facilitate radionuclide transport.

Additionally, microbial reactions may impact metal corrosion and therefore the integrity of the engineered barrier system (EBS). The combination of radionuclide mobility and EBS integrity ultimately controls total radionuclide release from a repository. 


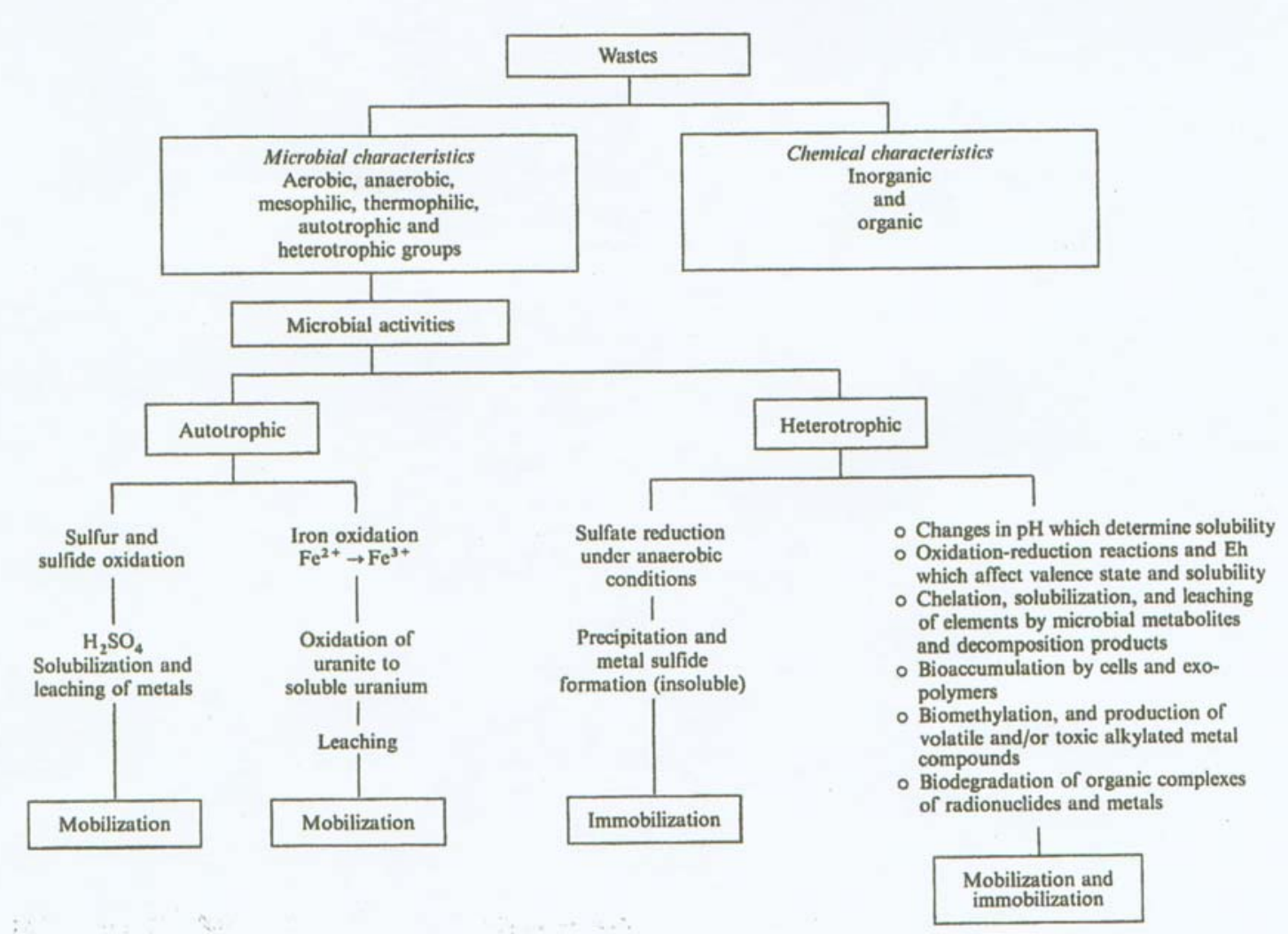

Source: Francis 1990 [DIRS 171093].

Figure 6.1-2. Microbial Transformations of Radionuclides and Metals in Wastes

Mobilization or immobilization of radionuclides by the activities of autotrophs (in the case of inorganic compounds) and by heterotrophs (in mixed wastes containing organics) could be significant (Francis 1990 [DIRS 171093], Figure 6.1-2):

- Autotrophic activity. The iron and sulfur oxidizing bacteria play a significant role in the solubilization of uranium from ores and mill tailings. The biogeochemistry of uranium has been extensively studied in light of the recovery of $U$ from ores. Microbial leaching of pyretic uranium ore is primarily indirect, and confined to the generation of the oxidizing agent, ferric sulfate, and the solvent sulfuric acid. The indirect involvement of $\mathrm{Fe}^{2+} / \mathrm{Fe}^{3+}$ in the process of cyclically mediating the oxidation of the insoluble uranium oxide has been documented: $\mathrm{UO}_{2}+\mathrm{Fe}^{3+} \rightarrow \mathrm{UO}_{2}{ }^{2+}+2 \mathrm{Fe}^{2+}$. T. ferroxoxidans can also directly oxidize reduced compounds of uranium (uranous sulfate and $\mathrm{UO}_{2}$ ) to their hexavalent form without the involvement of extraneous $\mathrm{Fe}^{3+} / \mathrm{Fe}^{2+}$ complex as the chemical electron carrier. Iron- and sulfur-oxidizing bacteria (T. ferrooxidans and T. thiooxidans) were isolated from several uranium ores.

- Heterotrophic activity. An increase in heterotrophic microbial activity due to biodegradation of organic compounds can affect the solubility of radionuclides and metals. Heterotrophic bacteria and fungi are able to release metals from various 
materials, including copper-nickel concentrates, low-grade copper ore, uranium and manganese ore. Several mechanisms for heterotrophic aerobic microbial solubilization of insoluble metal have been proposed. These include organic acid production, formation of chelating agents, and metabolism of metal-associated anion. Leaching by heterotrophic organisms is entirely due to chemical reaction of excreted microbial metabolites and decomposition products.

Figures 6.1-1 and 6.1-2 provide a theoretical framework for the evaluation of the microbial activity within the repository. Note that (in addition to the processes described in Figure 6.1-1 and Figure 6.1-2) temperature, water availability, and radiation will play an important role in the regulation of microbial activities within the repository during relevant periods.

\subsubsection{Status of Repository-Related Microbiological Studies}

In the past two decades, numerous studies have been conducted on microbial population distributions related to nuclear waste disposal. The results are summarized in Tables 6.1-3 through 6.1-6. For example, a survey of microbial population distributions in water and subsoil samples (from deep mines designated for disposal of high-level radioactive waste in Europe) was conducted by West et al. (1985 [DIRS 110047]; 1986 [DIRS 171088]). They reported finding a variety of organisms representing autotrophic and heterotrophic groups that include native organisms and organisms introduced from mining operations. The presence of active microbial populations in deep subsurface environments clearly suggests that, under certain conditions, these microbes could play a significant role in the transformation and transport of radionuclides in the subsurface environments. Furthermore, microbial effects on low-level radioactive wastes disposed of in shallow-land burial grounds, and their potential effects in deep geological formations, are of considerable interest for assessing the performance of waste repositories, and from the standpoint of environmental remediation of contaminated sites. Microorganisms have been detected in backfill materials, natural analogue sites, plutonium-contaminated soils, low-level radioactive wastes, and waste-repository sites slated for high-level radioactive wastes. It can be seen from Tables 6.1-3 to 6.1-6 that microbial population varies greatly between locations within a specific site and between different sites. Microbial populations at the surveyed sites are generally lower than $10^{7}$ cells per gram, with the exception of populations found within some bentonite materials, in which the population can be higher than $10^{11}$ cells per gram. Generally, it is difficult to correlate the presence of specific organisms with site conditions. The presence of a specific set of bacteria does not guarantee that they will be active; some of them may be dormant if conditions are not conducive to their active state. This implies that data on microbial population alone are not able to provide sufficient information on the geochemical impact of microbial activities.

Efforts also have been made to model the microbial processes within repositories. McKinley et al. (1997 [DIRS 100796]) proposed an approach to calculating the upper limit of microbial population, based on energy and mass balance. In this approach, all possible redox reactions are first identified, and the total energy released from these reactions is calculated from the change in Gibbs free energy of formation across each reaction. The calculated energy is then converted to the number of microbial cells. The maximum microbial population can also be estimated from a mass balance calculation of nutrients. Another modeling approach has been developed based on the determination of individual metabolic pathways and their relative contributions. For 
instance, Humphreys et al. (1997 [DIRS 171127]) developed a biogeochemical source term model for low-level radioactive waste disposal. In this model, both microbial degradation and metal corrosion were considered. Monod kinetics were used to describe microbial processes. A similar, but simpler, approach was used to describe microbial gas generation in the WIPP repository (Wang et al. 1997 [DIRS 171122]).

The first approach, which is primarily focused on the upper bounds of biomass production, is not sufficient for addressing the overall impacts of microbial activity on repository chemistry. Therefore, this approach, though previously adopted by the YMP (CRWMS M\&O 2000 [DIRS 151561]), is no longer intended for use in this report. Importantly, in the current repository design, organic components that could contribute to microbial growth have been eliminated from the list of committed materials (BSC 2004 [DIRS 170058]). This design change allows us to evaluate microbial activity in the Yucca Mountain repository using simple bounding calculations with relevant environmental constraints.

Table 6.1-3. Abundance of Microorganisms in Plutonium-Contaminated Soils and Radioactive Wastes

\begin{tabular}{|c|c|c|c|}
\hline Sample Source & $\begin{array}{c}\text { Plutonium } \\
\text { Concentration }\end{array}$ & Microorganisms Detected & Reference \\
\hline $\begin{array}{l}\text { SOIL } \\
\text { Nevada Test Site } \\
\text { Area } 13 \\
\text { (Soil pH } 8.4-9.2 \text { ) }\end{array}$ & $N / A$ & $\begin{array}{l}\text { Bacteria } \\
2.9 \pm 0.3 \text { to } 8.0 \pm 0.7 \times 10^{6} / \mathrm{g} \\
\text { Fungi } \\
3.1 \pm 0.7 \text { to } 24.6 \pm 2 \times 10^{3} / \mathrm{g}\end{array}$ & $\begin{array}{l}\text { Au and Leavitt } 1982 \\
\text { [DIRS 171090] }\end{array}$ \\
\hline $\begin{array}{l}\text { Los Alamos National Labs } \\
\text { TRU waste shallow burial } \\
\text { site TA-54, } \\
\text { Area C }\end{array}$ & $\mathrm{N} / \mathrm{A}$ & $\begin{array}{l}\text { Bacteria } \\
\qquad \begin{array}{l}\text { aerobes: } 2.3 \times 10^{6} / \mathrm{g} \\
\text { anaerobes: } 3.3 \times 10^{6} / \mathrm{g}\end{array} \\
\begin{array}{l}\text { Actinomyctetes } \\
\text { detected with depth, not } \\
\text { counted }\end{array} \\
\text { Fungi } \quad \\
\\
4.9 \times 10^{4} / \mathrm{g}\end{array}$ & $\begin{array}{l}\text { Barnhart et al. } 1979 \\
\text { [DIRS 171092] }\end{array}$ \\
\hline $\begin{array}{l}\text { SEDIMENT/WATER: } \\
\text { Rocky Flats Plant: Pond } \\
\text { B1 } \\
\text { Sediment } \\
\text { (Total Pu } 81.5 \mathrm{mCi} \text { ) }\end{array}$ & $1000 \mathrm{dpm} / \mathrm{g}$ & $\begin{array}{l}\text { Bacteria } \\
\qquad \begin{array}{l}\text { aerobes: } 3-300 \times 10^{6} / \mathrm{mL} \\
\text { anaerobes: } 0.2-2.0 \times 10^{6} / \mathrm{mL}\end{array}\end{array}$ & $\begin{array}{l}\text { Johnson et al. } 1974 \\
\text { [DIRS 171153] }\end{array}$ \\
\hline Water & $\mathrm{N} / \mathrm{A}$ & $\begin{array}{l}\text { aerobes: } 1.1-340 \times 10^{3} / \mathrm{mL} \\
\text { anaerobes: } 2-7.8 \times 10^{2} / \mathrm{mL}\end{array}$ & \\
\hline
\end{tabular}


Table 6.1-3. Abundance of Microorganisms in Plutonium-Contaminated Soils and Radioactive Wastes (Continued)

\begin{tabular}{|c|c|c|c|}
\hline Sample Source & $\begin{array}{c}\text { Plutonium } \\
\text { Concentration }\end{array}$ & Microorganisms Detected & Reference \\
\hline $\begin{array}{l}\text { WASTE - SOLIDS: } \\
{ }^{239} \mathrm{Pu} \text { contaminated waste } \\
\text { from a steel burial drum }\end{array}$ & $\mathrm{N} / \mathrm{A}$ & $\begin{array}{l}\text { Bacteria } \\
\qquad \text { aerobes: } 33 \text { - 9500/sample } \\
\text { Fungi: } 46 \text { CFU/sample }\end{array}$ & $\begin{array}{l}\text { Barnhart et al. } 1979 \\
\text { [DIRS 171092] }\end{array}$ \\
\hline $\begin{array}{l}\text { Waste leachates: } \\
\text { Maxey Flats, KY } \\
\text { Trench 19S: } \\
{ }^{238} \mathrm{Pu} \\
{ }^{239,240} \mathrm{Pu}\end{array}$ & $\begin{array}{l}170000 \mathrm{pCi} / \mathrm{L} \\
210000 \mathrm{pCi} / \mathrm{L}\end{array}$ & $\begin{array}{l}\text { Bacteria } \\
\qquad \begin{array}{l}\text { aerobes: } 2.2 \times 10^{2} \mathrm{CFU} / \mathrm{mL} \\
\text { anaerobes: } 3.2 \times 10^{2} \mathrm{CFU} / \mathrm{mL}\end{array}\end{array}$ & $\begin{array}{l}\text { Francis } 1990 \\
\text { [DIRS 171093] }\end{array}$ \\
\hline
\end{tabular}

$\mathrm{N} / \mathrm{A}=$ not available.

Table 6.1-4. Bacteria Detected in Radioactive Waste Repository Environments

\begin{tabular}{|l|l|l|}
\hline \multicolumn{1}{|c|}{ Site } & \multicolumn{1}{|c|}{ Bacteria Detected } & \multicolumn{1}{|c|}{ Reference } \\
\hline $\begin{array}{l}\text { Waste Isolation Pilot Plant (WIPP), } \\
\text { (pH 7) }\end{array}$ & $\begin{array}{l}\text { Repository Groundwater } \\
\text { Far-field: } 1.02 \pm 0.49 \times 10^{5} \text { cells } / \mathrm{mL} \\
\text { Near-field: } 1.24 \pm 0.13 \times 10^{5} \text { cells } / \mathrm{mL} \\
\text { (denitrifiers, fermenters, sulfate reducers, } \\
\text { methanogens }\end{array}$ & $\begin{array}{l}\text { Francis et al. 1998 } \\
\text { [DIRS 171078] }\end{array}$ \\
\hline Nevada Test Site, USA & $\begin{array}{l}\text { Study Site Groundwater } \\
10^{2} \text { viable cells } / \mathrm{mL} \text { (Pseudomonas, } \\
\text { Acinetobacter) }\end{array}$ & $\begin{array}{l}\text { Amy et al. 1992 } \\
\text { [DIRS 116973] }\end{array}$ \\
\hline $\begin{array}{l}\text { Äspö Hard Rock Lab, Sweden granite } \\
\text { fracture zone (pH 7.5) }\end{array}$ & $\begin{array}{l}0.44-9.3 \times 10^{5} \text { cells } / \mathrm{mL} \text { (methanogens and } \\
\text { homoacetogens) }\end{array}$ & $\begin{array}{l}\text { Pedersen et al. 1996 } \\
\text { [DIRS 171101] }\end{array}$ \\
\hline $\begin{array}{l}\text { Grimsel Test Site, Switzerland granite } \\
\text { shear zone (pH 10) }\end{array}$ & $\begin{array}{l}3.97 \pm 0.37 \times 10^{3} \text { cells } / \mathrm{mL} \text { (fermenters and } \\
\text { homoacetogens) }\end{array}$ & $\begin{array}{l}\text { Gillow et al. 2000 } \\
\text { [DIRS 171096] }\end{array}$ \\
\hline Yucca Mountain tuff, Nevada, USA & $0.32-2.0 \times 10^{5}$ cells $/ \mathrm{g}$ & $\begin{array}{l}\text { Kieft et al. 1997 } \\
\text { [DIRS 100767] }\end{array}$ \\
\hline
\end{tabular}

Table 6.1-5. Number of Bacteria at Natural Analogue Sites

\begin{tabular}{|c|c|c|}
\hline Analogue Site & Bacteria Detected & Reference \\
\hline $\begin{array}{l}\text { Cigar Lake uranium ore deposit, } \\
\text { Saskatchewan, Canada - } \\
\text { sandstone w/ clay-hosted U ore }\end{array}$ & $\begin{array}{l}\text { Groundwater: } 4.7 \times 10^{2}-4.4 \times 10^{4} \text { cells } / \mathrm{mL} \\
\text { (denitrifiers, fermenters, sulfate reducers, } \\
\text { methanogens) } \\
\text { Ore: } 1.4 \pm 0.9 \times 10^{5} \mathrm{cfu} / \mathrm{g} \text { viable cells } \\
\text { (denitrifiers) }\end{array}$ & $\begin{array}{l}\text { Francis et al. } 1994 \\
\text { [DIRS 110014] }\end{array}$ \\
\hline Pocos de Caldos, Brazil & Yes & $\begin{array}{l}\text { West et al. 1992 } \\
\text { [DIRS 171109] }\end{array}$ \\
\hline Oklo, Gabon, Africa & Yes & $\begin{array}{l}\text { Pedersen et al. } 1996 \\
\text { [DIRS 171103] }\end{array}$ \\
\hline Yucca Mountain tuff, Nevada, USA & $0.32-2.0 \times 10^{5}$ cells $/ g$ & $\begin{array}{l}\text { Kieft et al. } 1997 \\
\text { [DIRS 100767] }\end{array}$ \\
\hline
\end{tabular}


Table 6.1-6. Microbial Population in Backfill Materials Proposed for Use at the Radioactive Waste Repositories

\begin{tabular}{|l|l|l|}
\hline \multicolumn{1}{|c|}{ Backfill } & \multicolumn{1}{|c|}{ Bacteria Detected } & \multicolumn{1}{c|}{ Reference } \\
\hline Wyoming bentonite & $\begin{array}{l}5.32 \pm 0.34 \times 10^{11} \mathrm{cells} / \mathrm{g} ; \\
<1.07 \pm 3.54 \times 10^{2} \mathrm{cfu} / \mathrm{g} \text { viable cells }\end{array}$ & $\begin{array}{l}\text { Haveman et al. 1995 } \\
\text { [DIRS 171097] }\end{array}$ \\
\hline Avonlea bentonite & $6.29 \pm 0.75 \times 10^{11} \mathrm{cells} / \mathrm{g} ;$ & Haveman et al. 1995 \\
& $3.48 \pm 0.56 \times 10^{4} \mathrm{cfu} / \mathrm{g}$ viable cells & [DIRS 171097] \\
\hline $\begin{array}{l}\text { Canadian sand and } \\
\text { bentonite buffer material }\end{array}$ & $\begin{array}{l}10^{1} \text { to } 10^{6} \text { viable cells/g } \\
\text { (Acinetobacter, Pseudomonas) }\end{array}$ & $\begin{array}{l}\text { Stroes-Gascoyne et } \\
\text { al. 1997 } \\
\text { [DIRS 171108] }\end{array}$ \\
\hline
\end{tabular}

\subsection{FEATURES, EVENTS, AND PROCESSES ADDRESSED BY THIS ANALYSIS}

Tables 6.2-1 and 6.2-2 list the FEPs that are addressed in this report in accordance with the technical work plan (TWP) (BSC 2004 [DIRS 172402], Section 2.5), and DTN: MO0407SEPFEPLA.000 [DIRS 170760]. The tables provide specific references to sections within this document. The FEP numbers and names from the TWP have been corrected to match the DTN.

Table 6.2-1. FEPs Included in the TSPA-LA and Addressed by This Document

\begin{tabular}{|l|l|c|}
\hline FEP No. & \multicolumn{1}{|c|}{ FEP Name } & $\begin{array}{c}\text { Section of Document } \\
\text { Where FEP Is } \\
\text { Addressed }\end{array}$ \\
\hline $2.1 .09 .01 .0 \mathrm{~A}$ & Chemical characteristics of water in drifts & 6.5 \\
\hline $2.1 .09 .02 .0 \mathrm{~A}$ & Chemical interaction with corrosion products & 6.5 \\
\hline $2.1 .09 .06 .0 \mathrm{~B}$ & Reduction-oxidation potential in drifts & 6.4 .2 \\
\hline $2.1 .11 .08 .0 \mathrm{~A}$ & Thermal effects on chemistry and microbial activity in the EBS & 6.4 .1 \\
\hline
\end{tabular}

Table 6.2-2. FEPs Excluded in the TSPA-LA and Addressed by This Document

\begin{tabular}{|c|l|c|}
\hline FEP No. & \multicolumn{1}{|c|}{ FEP Name } & $\begin{array}{c}\text { Section of Document } \\
\text { Where FEP Is } \\
\text { Addressed }\end{array}$ \\
\hline $1.1 .02 .00 .0 \mathrm{~A}$ & Chemical effects of excavation/construction in EBS & 6.4 .5 \\
\hline $2.1 .06 .01 .0 \mathrm{~A}$ & $\begin{array}{l}\text { Chemical effects of rock reinforcement and cementitious } \\
\text { materials in EBS }\end{array}$ & 6.4 .5 \\
\hline $2.1 .10 .01 .0 \mathrm{~A}$ & Microbial activity in EBS & 6.4 \\
\hline $2.1 .12 .01 .0 \mathrm{~A}$ & Gas generation (repository pressurization) & 6.5 .1 \\
\hline
\end{tabular}




\subsection{CHARACTERIZATION OF THE MICROBIAL POPULATION AT YMP}

The repository is located in an unsaturated zone of welded volcanic tuff. Thus, the geochemical impact of microbial activity within the repository should be considered in the context of physical, chemical, and hydrologic conditions in vadose zones. Characterization of microbial communities has principally focused on correlating the types, numbers, and activities of present microorganisms to extant geological features, and with water and carbon availability (Colwell 1989 [DIRS 171111]; Haldeman and Amy 1993 [DIRS 145228]; Kieft et al. 1997 [DIRS 100767], 1998 [DIRS 171098]; Brockman et al. 1992 [DIRS 171110]; Russell et al. 1994 [DIRS 119578]). These studies, along with those examining the activities of subsurface isolates in pure cultures, have shown bacteria are present in all vadose zones examined thus far. The contributions of microorganisms to chemical reactions that affect geological processes and mass transfer have been affirmed.

The quantity of intact phospholipid fatty acids (PLFA) is a direct indicator of viable or potentially viable cells in an environmental sample. Thus, PLFA analysis permits the direct quantification of microbial biomass in environmental samples without the need for culturing microorganisms (Tunlid and White 1992 [DIRS 120501]). Quantitative analysis of the total number of bacteria present in a Yucca Mountain rock sample aseptically collected from the Exploratory Studies Facility (ESF) was undertaken using this technique (Horn et al. 2004 [DIRS 171058]). A single rock core was collected and cut into two pieces: one piece consists of the region facing the tunnel (proximal to the drift), and the other piece is the area reaching into the tunnel wall (distal to the drift). Using this method, it was deduced that the proximal sample contained $6 \times 10^{4}$ cells per gram of dry rock (3 pmole $(\mathrm{pM})$ of PLFA/g dry rock); the deeper-dwelling distal sample had $4 \times 10^{4}$ cells per gram of dry rock ( 2 pM of PLFA/g dry rock), using a conversion factor of $2 \times 10^{4}$ cells/pM PLFA. No diglycerides, an indicator of dead bacteria, were detected. The PLFA analysis showed a preponderance of gram-negative organisms.

Subsurface environments have demonstrated high proportions of heterotrophic bacteria (Balkwill 1989 [DIRS 171091]), especially in studies of oxygenated volcanic tuff at the Nevada Test Site (Amy et al. 1992 [DIRS 116973]; Haldeman and Amy 1993 [DIRS 145228]). Microbial analyses conducted in the ESF have determined the existence of aerobic heterotrophs and autotrophs (Ringelberg et al. 1997 [DIRS 100824]), including iron oxidizing, sulfur oxidizing and nitrifying organisms. Cell counts for autotrophs range between 10 and 500 cells per gram dry weight and, for the heterotrophs, between $3.2 \times 10^{4}$ to $2 \times 10^{5}$ cells per gram of tuff. The relatively small population of autotrophs reflects the oxidizing environment at Yucca Mountain, which is not conducive to sustaining autotrophic bacteria. Microbial growth in various tuffs has been investigated (Horn et al. 2003 [DIRS 167221]). After a one-year incubation in microcosms fed with 10xJ13 Synthetic groundwater, microorganisms were collected from the microcosm efflux and plated on R2A agar (Horn et al. 2003 [DIRS 167221]). An effort was made to single-colony purify as many individual morphotypes as could be discerned; these were subjected to Biolog analysis to eliminate duplicate strains, and then identified using 16S rDNA sequence determination and analysis (Lane et al. 1985 [DIRS 171119]). Six different organisms were identified after growth in 10xJ13 Synthetic medium by determination of their closest relatives extant within the examined databases: Ralstonia pickettii, Burkholderia cepacia, Sphingomonas paucimobilis, Blastobacter natatorius, Caulobacter subvibroidies, and 
Methylobacterium mesophilicum. All of these isolates, with the exception of the M. mesophilicum, demonstrated a 3-percent or less rDNA sequence divergence from reference organisms in the existing GenBank and Microseq databases, thereby showing close phylogenetic relationships to reference organisms (Benson et al. 2000 [DIRS 171117]; Stackebrandt and Goebel 1994 [DIRS 171105]; Patel et al. 2000 [DIRS 171100]).

Stationary phase cultures grown in 1xJ13 Synthetic medium both with or without added glucose were also subjected to single-colony purification, Biolog analysis, and 16S rDNA analysis (Horn et al. 2003 [DIRS 167221]). These generally showed greater rDNA sequence divergence from database reference strains than did isolates derived after growth in 10xJ13 Synthetic medium, thereby demonstrating a 3.45-percent median divergence (3.88 percent average) from reference strains in the MicroSeq and Genbank databases (Table 6.3-1). Although formally they cannot be considered identical species since sequence divergence is greater than 3 percent (Stackebrandt and Goebel 1994 [DIRS 171105]), for ease of reference, these organisms are referred to here by the name of their closest relatives.

Virtually all of the organisms isolated from 1xJ13 Synthetic-grown cultures were not found in 10xJ13 Synthetic medium cultures, although Ralstonia-like bacteria were found in all cultures, and Sphingomonads were present in 10xJ13 Synthetic-grown cultures and in 1xJ13 Synthetic-grown cultures without glucose (Horn et al. 2003 [DIRS 167221]). Similarly, most of the organisms grown in 1xJ13 Synthetic with glucose differed from those isolated from 1xJ13 Synthetic without glucose; the single exception was a Microbacterium keratanolyticum-like bacteria (Table 6.3-1).

Even though identical organisms were not isolated from all cultures, most of the isolates cultured from 1xJ13 Synthetic without glucose correlated to phylogenetically related isolates in either 1xJ13 Synthetic with glucose or 10xJ13 Synthetic. Pseudomonas stutzeri-like organisms were found in 1xJ13 cultures; its close relative, B. cepacia, was identified from 10xJ13 Synthetic-grown cultures.

Two of the isolates that were grown from rock when using 1xJ13 Synthetic with glucose as a growth medium were identical or related to isolates obtained from other studies that examined diversity within alternative systems (Horn et al. 2003 [DIRS 167221]). Arthrobacter SMCC G964 was isolated from a saturated zone in fine-grained lacustrine sediments, at a depth of approximately $173 \mathrm{~m}$, in Hanford, Washington (Van Waasbergen et al. 2000 [DIRS 171075]); it is completely homologous to a strain isolated from Yucca Mountain tuff. Bacterium oxSCC was identified from a 16S rDNA analysis of the oxic zone of flooded paddy soils collected in Vercelli, Italy (Lüdemann et al. 2000 [DIRS 171074]); it is the nearest sequenced relative of an isolate identified here. That these homologues were found in very different environments and in widely disparate locales attests to their adaptability and their ability to compete in alternative types of strata, and is evidence of their widespread distribution. 
Table 6.3-1. Organisms Isolated After Growth in Various Yucca Mountain Simulated Groundwaters and $16 S$ rDNA Sequence Divergence from Reference Organisms

\begin{tabular}{|l|c|c|}
\hline \multirow{2}{*}{\multicolumn{1}{c|}{ Organism }} & \multicolumn{2}{c|}{ Growth Medium from Which Organism Isolated } \\
\cline { 2 - 3 } & \multicolumn{2}{|c|}{ \% Divergence from Database } \\
\cline { 2 - 3 } & - & - \\
\hline Ralstonia pickettii & $4.5 / \mathrm{MS}$ & $6.9 / \mathrm{MS}$ \\
\hline Ralstonia eutrophus & - & - \\
\hline Burkholderia cepacia & - & - \\
\hline Blastobacter natatorius & - & $2.0 / \mathrm{GB}$ \\
\hline Sphingomonas paucimobilis & - & - \\
\hline Methylobacterium mesophilicum & - & - \\
\hline Caulobacter subvibroidies & $4.0 / \mathrm{GB}$ & - \\
\hline Uncultured bacterium oxSCC-6 & $6.06 / \mathrm{MS}$ & - \\
Pseudomonas (Janth) mephitica & $4.5 / \mathrm{MS}$ & $4.15 / \mathrm{MS}$ \\
\hline Microbacterium barkeri & $4.15 / \mathrm{MS}$ & - \\
\hline Microbacterium keratanolyticum & $5.16 / \mathrm{MS}$ & - \\
\hline Microbacterium chocolatum & $0.0 / \mathrm{GB}$ & $1.0 / \mathrm{GB}$ \\
\hline Arthrobacter sp. SMCC G964 ${ }^{\mathrm{c}}$ & $3.93 / \mathrm{MS}$ & $4.0 / \mathrm{GBMS}$ \\
\hline Pseudomonas stutzeri & - & \\
\hline Afipia genosp. & & \\
\hline
\end{tabular}

Source: Horn et al. 2004 [DIRS 171058].

MS = MicroSeq database $; \mathrm{GB}=$ GenBank database $; \mathrm{RDP}=$ Ribosomal Database project.

${ }^{a}$ Closest relative in $16 \mathrm{~S}$ rDNA sequence comparisons to three separate databases (i.e., MS, GB, and RDP).

${ }^{b}$ Lüdemann et al. 2000 [DIRS 171074]. Spatial changes in the bacterial community structure along a vertical oxygen gradient in flooded paddy soil cores.

${ }^{c}$ Van Waasbergen et al. 2000 [DIRS 171075]. Genetic diversity among Arthrobacter species collected across a heterogeneous series of terrestrial deep-subsurface sediments, as determined on the basis of 16S rRNA and recA sequences.

It has been commonly acknowledged that only a small fraction of organisms (extant in any given environmental sample) grow and can be isolated on a single type of growth medium. Therefore, methods that use direct DNA extraction from environmental samples, with subsequent characterization of the 16S rDNA genes in the obtained DNA, have been developed to better assess community compositions without the need to grow and isolate organisms. Characterization of DNA extracted directly from Yucca Mountain rock was therefore undertaken to generate a more complete roster of the organisms contained within the Yucca Mountain community (Horn et al. 2003 [DIRS 167221]). Four hundred grams of Yucca Mountain rock were subjected to extraction. The resulting DNA was purified and subjected to a series of biochemical and genetic manipulations that included amplification of microbial 16S rDNA genes and cloning amplified genes. Two hundred rDNA clones were screened to obtain those that were unique based on restriction fragment length polymorphisms.

Note that collected rocks may contain both native organisms and organisms introduced by construction. No effort has been made to distinguish between them, because both may affect repository environments. Statistical analysis that involved the screening of 200 clones confirmed that those organisms representing more than 3.5 percent of the community have a 0.1 percent probability of not being detected. Conversely, those organisms that represent less than 
0.5 percent of the Yucca Mountain community have a 37-percent probability of not being detected. Therefore, although screening 200 clones may not detect all organisms extant at the site, the vast majority of organisms were detected, and only those that represented a very small percentage of the total microbial community would not have been detected and identified.

Frequency of Unique Clone Types in Yucca Mountain Rock

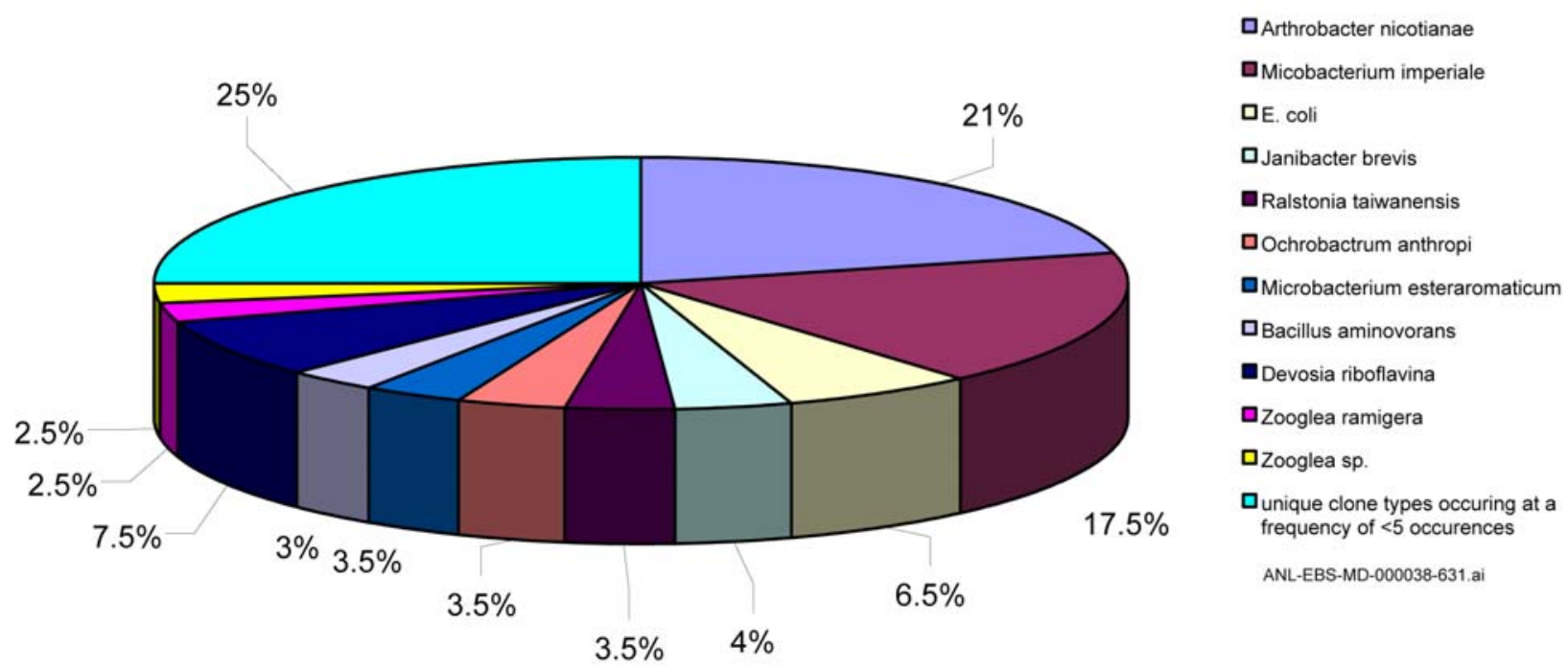

Source: Horn et al. 2003 [DIRS 167221].

NOTE: After amplification and cloning of 16S rDNA genes, 200 clones were screened; the frequency of occurrence of unique clone types is depicted as the percentage of the total number of clones screened.

Figure 6.3-1. Frequency of Unique Clone Types in Yucca Mountain Rock (of 200 Screened)

After screening 200 rDNA clones, 65 unique clonal types, representing 65 separate types of organisms, were distinguished (Horn et al. 2003 [DIRS 167221]). The frequency of occurrence during screening may indicate the relative abundance of these organisms in the Yucca Mountain rock samples (Figure 6.3-1).

After sequencing, an evolutionary (or "phylogenetic") tree of all unique cloned sequences was generated, together with related reference organisms from the rDNA database (Horn et al. 2003 [DIRS 167221], Figure 6.3-2). These trees show the relatedness between the organisms that were identified, and known extant organisms; nodes denote common evolutionary ancestors; the length of branches connote evolutionary time since divergence from a common ancestor. Identified Yucca Mountain organisms span a wide phylogenetic range, and include groups of organisms known to reside in dry environments (e.g., the High Guanine (G) + Cytosine (C) Gram Positives), in addition to those that sporulate into resistant forms that can survive desiccation and elevated temperatures (e.g., the Bacilli and Clostridia). When collecting rock samples for extraction, no effort was made to isolate purely endogenous Yucca Mountain organisms; both those from tunnel walls (which may be introduced during construction) and those within the rock were collected. Clearly, at least two identified Yucca Mountain organisms were introduced into the repository; these were related to photosynthetic cyanobacteria, which 
may be able to survive due to the artificial light or could be plant pollens that were introduced by ventilation of the ESF.

In summary, the site characterization studies have demonstrated both the variability in population and the diversity in genetic types for microorganisms present at the Yucca Mountain site. These microorganisms are highly adaptable and sufficiently diverse for carrying out any specific metabolic reaction that the environment permits. In other words, the extent of each individual microbial reaction will be limited by environmental constraints, not by the types of microbes present. Similarly, a specific group of microbes will thrive only to the extent that the environment allows. If conditions, however, are not conducive to activity, some microbial cells may be in a dormant state and therefore will not contribute to the overall biogeochemical process. This may be the reason for the difficulty in correlating microbial population distributions with geochemical environments. This argument is consistent with the modeling approach that has been used successfully over the years for modeling biogeochemical processes in aquatic sediments (e.g., Van Cappellen and Wang 1996 [DIRS 171128]; Wang and Van Cappellen 1996 [DIRS 171057]). In this approach, microbial population is not explicitly included. A theoretical basis for this has been provided by Wang and Papenguth (2000 [DIRS 171123]). 


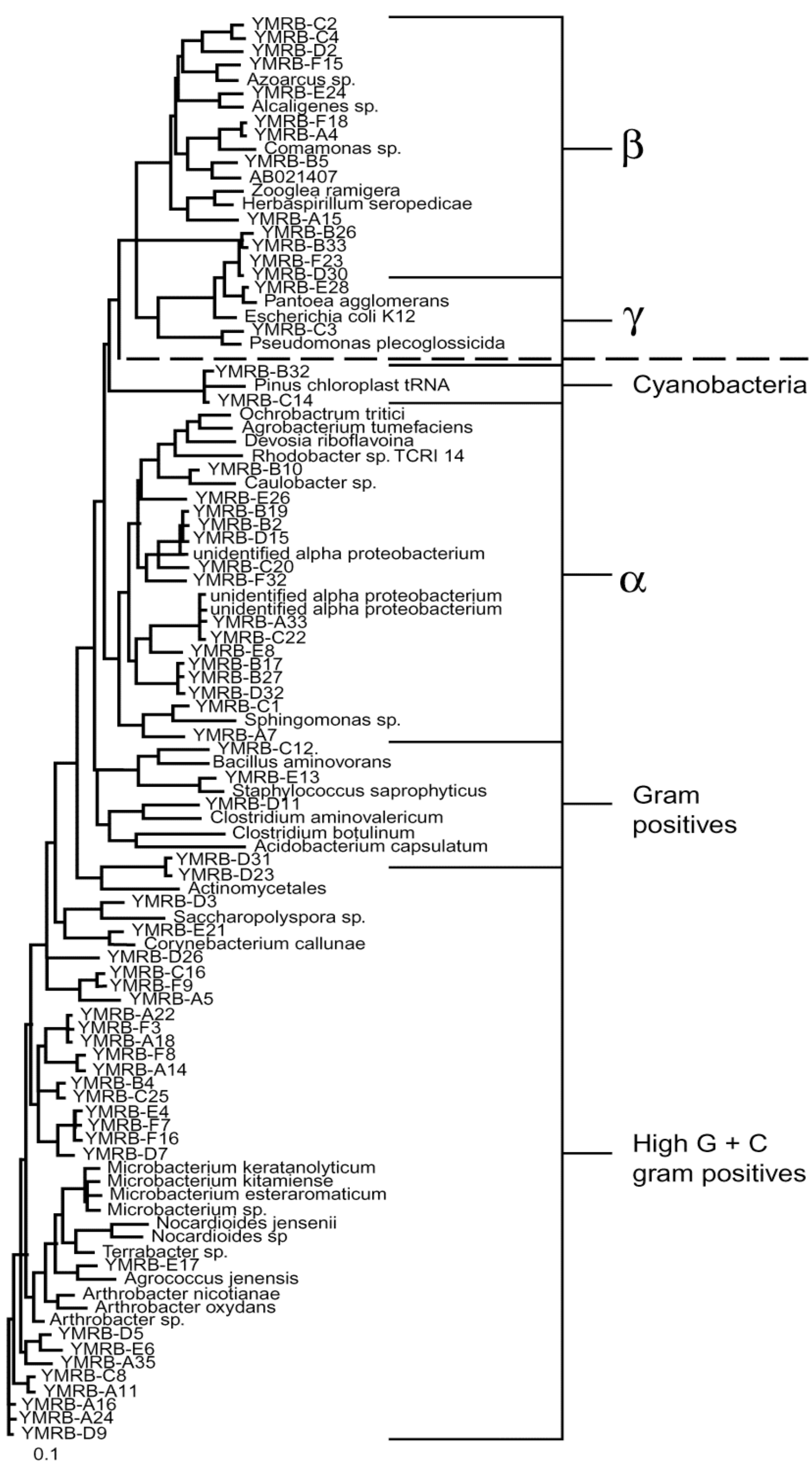

Change/sequence position

Source: DTN: LL021007312251.020 [DIRS 171179].

NOTE: Phylogenetic tree of Yucca Mountain microbial community as identified by $16 \mathrm{~S}$ rDNA analysis of DNA extracted from Yucca Mountain rock. Named species are those extant in the RDP database to serve as reference benchmarks; "YMRB-" designated strains are those identified from Yucca Mountain rock. Lengths of horizontal branches denote relative time since divergence from common ancestors (nodes). Large phylogenetic groupings are provided to the right of the tree.

Figure 6.3-2. Phylogenetic Tree of Yucca Mountain Microbial Community 
美 


\subsection{ENVIRONMENTAL CONSTRAINTS ON MICROBIAL ACTIVITY AT YMP}

This section on microbial activity in the repository addresses those impacts of FEP 2.1.10.0A (microbial activity in EBS) that do not involve the waste. This section considers various environmental constraints. The environmental factors considered include: temperature, pressure, oxic and anoxic conditions, relative humidity, water availability, $\mathrm{pH}$, salinity, nutrient availability, biofilm formation, and radiation effect. The evaluation shows that the high early temperatures, the otherwise oxic environment, and a relative scarcity of water and organic carbon will combine to limit microbial activity in the emplacement drifts.

\subsubsection{Temperature and Pressure Constraints}

This section addresses the aspects of FEP 2.11.08.0A (thermal effects on chemistry and microbial activity in the EBS) that involve microbial activity.

The temperature of the subsurface environment will affect or limit the type of bacteria that are present, based on the optimum growth temperatures of the organisms that are present. The maximum temperature at which known microorganisms can exist in an active state is $110^{\circ} \mathrm{C}$ (Table 4.1-2). Based on the growth of bacteria they are classified psychrophiles, facultative psychrophiles, mesophiles, thermophiles, and hyperthermophiles. Table 6.4-1 shows the ranges of temperatures supporting the growth of bacteria.

Table 6.4-1. Temperature Range for Microbial Growth

\begin{tabular}{|c|c|c|}
\hline Temperature Class & $\begin{array}{c}\text { Minima } \\
\text { Maxima }\end{array}$ & Optimum Range \\
\hline Psychrophiles & ${ }^{*}$ & $0^{\circ} \mathrm{C}$ to $15^{\circ} \mathrm{C}$ \\
\hline Facultative Psychrophiles & $20^{\circ} \mathrm{C}$ & $20^{\circ} \mathrm{C}$ to $30^{\circ} \mathrm{C}$ \\
& $0^{\circ} \mathrm{C}$ & $25^{\circ} \mathrm{C}$ \\
\hline Mesophiles & $15^{\circ} \mathrm{C}$ & $20^{\circ} \mathrm{C}$ to $45^{\circ} \mathrm{C}$ \\
& $45^{\circ} \mathrm{C}$ & $55^{\circ} \mathrm{C}$ to $65^{\circ} \mathrm{C}$ \\
\hline Thermophiles & $45^{\circ} \mathrm{C}$ & $80^{\circ} \mathrm{C}$ \\
\hline Hyperthermophiles & $60^{\circ} \mathrm{C}$ & $100^{\circ} \mathrm{C}$ \\
& $120^{\circ} \mathrm{C}$ & \\
\hline
\end{tabular}

Source: Pedersen and Karlsson 1995 [DIRS 100810].

* No lower bound reported.

Only a few of the identified isolates are known to withstand elevated temperatures ( $P$. stutzeri, R. pickettii, B. natatorius). Only one isolate, $M$. mesophilicum, is capable of forming cysts that are desiccation resistant; $M$. mesophilicum has also been found to be dominant in soils surrounding the Chernobyl Atomic Power Station (Overbeck 1997 [DIRS 171182]). Other bacteria, if they survive, will remain in a dormant state, without any contribution to the geochemical processes of interest. Sulfate-reducing bacteria isolated from a mine in Britain and Thiobacillus ferrooxidans found in several sites in Europe have been subjected to repository conditions in order to establish their ability to survive under these conditions (West et al. 1986 [DIRS 171088]). These experiments have included establishing growth curves, temperature 
tolerance tests, combined high pressure and temperature tolerance, and gamma-irradiation. The experimental data suggest that sulfate-reducing bacteria are more tolerant to extreme environmental conditions than the sulfur-oxidizing Thiobacillus ferroxidans (West et al. 1986 [DIRS 171088]). Sulfate-reducing bacteria, strict anaerobes, are not expected to be active in the oxidizing Yucca Mountain environment (Section 6.4.2).

Drift Scale Coupled Processes (DST and THC) Seepage Models (BSC 2004 [DIRS 169856], Figure 6.5-3) provides the in-drift thermal history predicted by a thermal-hydrologic model that accounts for heat conduction from the drift wall, into the rock matrix, resulting in vaporization and boiling, with vapor migration out of matrix blocks into fractures. The vapor moves away from the drift through the permeable fracture network by buoyancy, by the increased vapor pressure caused by heating and boiling, and through local convection. In cooler regions, the vapor condenses on fracture walls, where it drains through the fracture network either down toward the heat source from above, or away from the drift into the zone underlying the heat source. Slow imbibition of water from fractures into the matrix gradually leads to increases in the liquid saturation in the rock matrix. Under conditions of continuous heat loading due to radiation, a dryout zone may develop closest to the heat source separated from the condensation zone by a nearly isothermal zone maintained at about the boiling temperature. The predicted in-drift thermal history is shown in Figure 6.4-1.

During the period of thermal perturbation resulting from waste package emplacement, the temperature in the repository drifts could exceed $120^{\circ} \mathrm{C}$ (the upper temperature limit for the presence of microorganisms) and, for a waste package surface, could be as high as $170^{\circ} \mathrm{C}$ (Figure 6.4-1). Therefore, microbes initially present in the drift will be severely limited in growth, if not totally eliminated, by heating for a few hundred years at the early stage of the repository. As discussed in Section 6.4.3, during this heating period, relative humidity and water availability will also diminish; this will add another detrimental environmental factor to the survival of microorganisms.

Bacteria may migrate into the repository with infiltrating fracture flow, once temperatures decrease. Infiltrating organisms that survived the heating period may be presumed to colonize if conditions are favorable for growth. It is shown in Figure 6.4-1 that, even after the peak temperature, the in-drift temperature will remain above $50^{\circ} \mathrm{C}$ for the duration of the 10,000 -year regulatory period. Therefore, the microbial population will be dominated by thermophiles and hyperthermophiles.

Bacteria are able to withstand and flourish at the highest hydrostatic pressures on the planet (Madigan et al. 2003 [DIRS 171083]). Ordinary bacteria that have not been challenged by high hydrostatic pressure during their evolution are, nevertheless, remarkably tolerant to such pressure. At a high temperature, a high hydrostatic pressure may even help microbes to survive by preventing water loss from boiling and thus maintaining sufficient liquid water for microbes to carry out necessary metabolic reactions. Because the repository is located in an unsaturated zone, the in-drift gas pressure is close to atmospheric pressure. A significant microbial activity in the repository is possible only after the first 1,000 years, when the drift temperature drops below the boiling point (approximately $96^{\circ} \mathrm{C}$ ) (Figure 6.4-1). During the thermal event, the relative humidity is low enough to inhibit microbial growth (Section 6.4.3). 


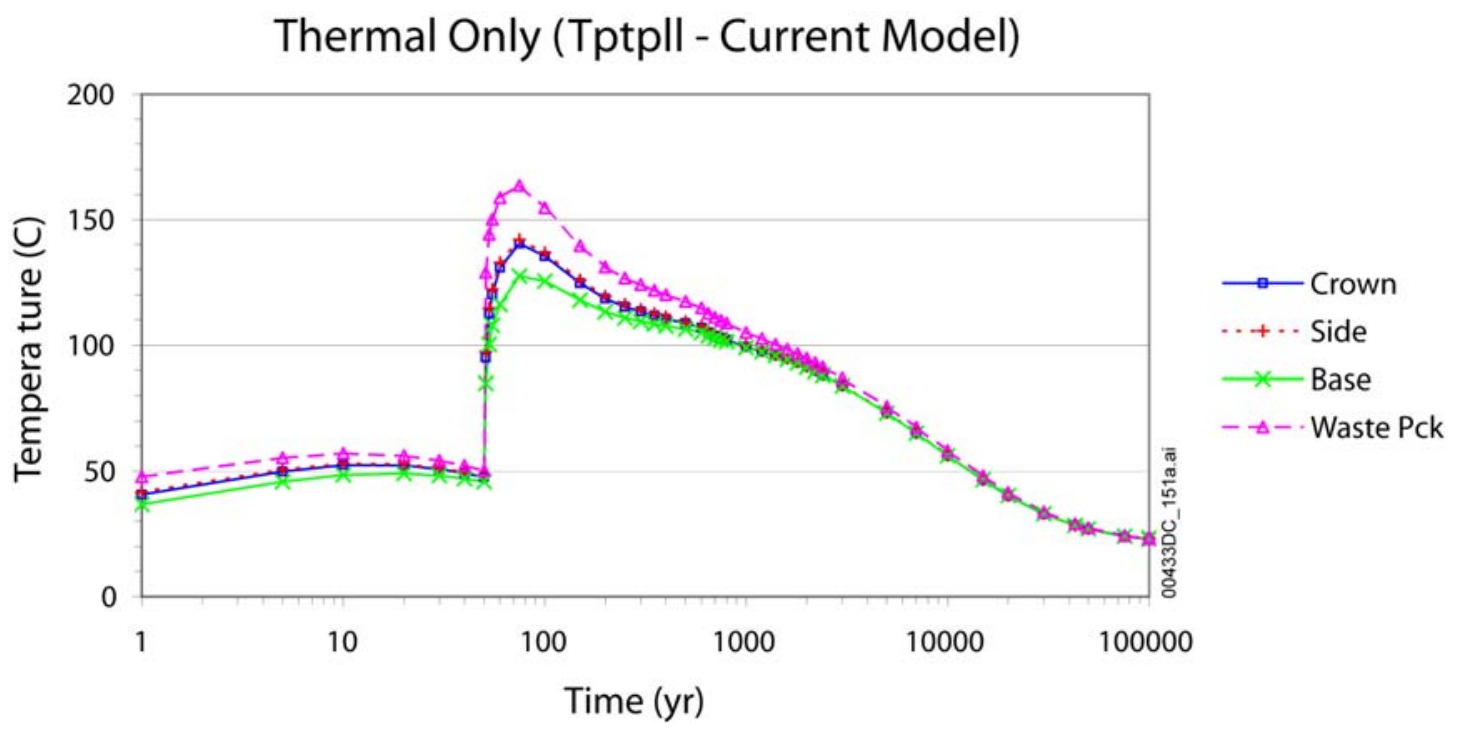

Source: BSC 2004 [DIRS 169856], Figure 6.5-3.

Figure 6.4-1. TH Simulation (Tptpll): Time Profiles of Modeled Temperatures in Fractures (Similar in Matrix) at Three Drift-Wall Locations and in the Waste Package

\subsubsection{Redox Conditions}

This section addresses the microbial aspects of FEP 2.1.09.06.0B (reduction-oxidation potential in drifts).

Bacteria that are able to grow in the presence of molecular oxygen, either in gaseous or dissolved form, are termed aerobes; those that can grow without oxygen are anaerobes. Table 6.4-2 shows the terms used to describe the $\mathrm{O}_{2}$ relations of bacteria. Thus, different microbes can thrive at various redox conditions, including both the oxygenated environments that are at high redox potential, and the reducing environments in which the oxygen abundance is minimal. Wang and Van Cappellen (1996 [DIRS 171057]) have shown that a typical limiting concentration of $\mathrm{O}_{2}$ for aquatic sediments is 1 to $30 \mu \mathrm{M}$ (approximately 0.4 to 10 percent atmospheric oxygen), above which anaerobic microbial reactions are completely inhibited.

Table 6.4-2. Oxygen Relationship and Growth of Bacteria

\begin{tabular}{|c|c|}
\hline Type & $\mathrm{O}_{2}$ Relation \\
\hline \multicolumn{2}{|l|}{ Aerobes } \\
\hline Obligate & $\mathrm{O}_{2}$ is required \\
\hline Facultative & $\mathrm{O}_{2}$ is not required, but growth is better with $\mathrm{O}_{2}$ \\
\hline Microaerophilic & $\mathrm{O}_{2}$ is required, but at lower-than-atmospheric levels \\
\hline \multicolumn{2}{|l|}{ Anaerobes } \\
\hline Aerotolerant & $\mathrm{O}_{2}$ is not required, and growth is not better with $\mathrm{O}_{2}$ \\
\hline Obligate (strict) & $\mathrm{O}_{2}$ is harmful or lethal \\
\hline
\end{tabular}

Source: Madigan et al. 2003 [DIRS 171083]. 
During the thermal pulse, water vapor will drive air mass away from the waste drift, thus resulting in depletion in oxygen concentration, which is proportional to the fraction of remaining air mass in the gas phase. The evolution of air mass in the drift has been calculated by the thermal-hydrologic model, and is shown in Figure 6.4-2. As shown in Figure 6.4-2, the air mass fraction will decrease to less than 10 percent during the thermal pulse, and will then quickly recover (back to 100 percent) after the thermal pulse, as does the oxygen concentration. However, the depletion in oxygen concentration is not expected to have an impact on microbial reaction pathways, because microbial activity will be severely limited, if not completely eliminated, due to both the heating and the desiccating effects, during the thermal pulse, as discussed in Section 6.4.1. Therefore, within the time window permissive for microbial activity (i.e., with temperature less than $100^{\circ} \mathrm{C}$ ), the oxygen concentration in the repository will be maintained above its limiting concentration (i.e., greater than 10 percent of atmospheric value). The overall chemical environment in the repository will therefore be oxic, and a significant anaerobic microbial activity will be unlikely. Some local anaerobic environments may exist in the rock matrix, but they will not affect repository chemical conditions, because such an effect, if there is one, is already accounted for by water chemistry measured at Yucca Mountain.

The assertion of an overall oxic environment in the repository is consistent with field observations (BSC 2004 [DIRS 169734], Section 5.2). Iron and manganese oxides/oxyhydroxides are the most common mineral phases found in the fractures in both saturated zones and UZs. The redox state of UZ waters is probably dominated by the presence of oxygen in the UZ gas phase. At the two locations where such measurements have been made, the UZ gas phase has atmospheric levels of oxygen. The measured $\mathrm{E}_{\mathrm{h}}$ values are typically high $(400$ to $600 \mathrm{mV})$. In addition to the oxic background environment, radiolysis of water inside the waste drift will generate hydrogen peroxide, thus adding another oxidizing agent to the water.

Nitrate $\left(\mathrm{NO}_{3}{ }^{-}\right)$is an inhibitor for metal corrosion as opposed to chloride $\left(\mathrm{Cl}^{-}\right)$, as summarized in General Corrosion and Localized Corrosion of the Waste Package Outer Barrier (BSC 2004 [DIRS 169984], Section 1.2). The ratio of $\mathrm{NO}_{3}{ }^{-} / \mathrm{Cl}^{-}$is an important parameter in the control of the longevity of the waste package and drip shield as engineered barriers. In principle, microorganisms could consume nitrate through denitrification, either heterotrophically or autotrophically, under anaerobic conditions (Korom 1992 [DIRS 172324], pp. 1657 to 1668). This, however, will be unlikely in the repository because the overall environment will be oxic, which, together with low organic-carbon concentrations, will prevent significant anaerobic microbial reactions, including denitrification, as shown by the field observation that a significant amount of $\mathrm{NO}_{3}{ }^{-}$is currently present in groundwaters. Even if some anaerobic microenvironments may exist in rock matrix, their impact on nitrate concentration has already been captured by the current water analysis. 

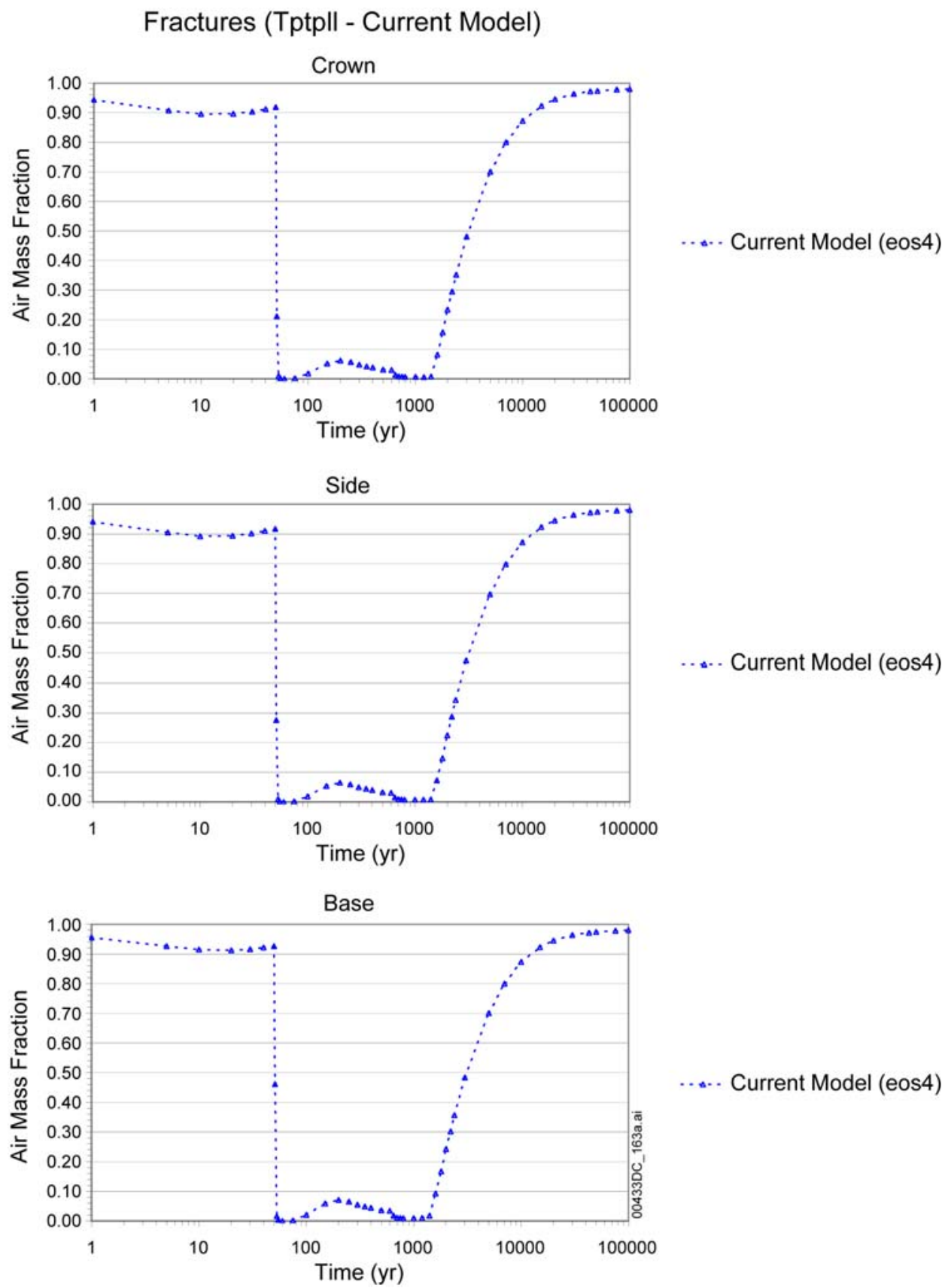

Source: BSC 2004 [DIRS 169856], Figure 6.5-8.

NOTE: Oxygen concentrations are proportional to air mass fractions.

Figure 6.4-2. Temporal Evolution of Air Mass Fractions in the Gas Phase in Fractures and Matrix at Three Drift-Wall Locations

Furthermore, the oxidizing environment will also prevent the generation or accumulation of reduced inorganic species (e.g., $\mathrm{H}_{2}, \mathrm{NH}_{4}^{+}, \mathrm{NO}_{2}^{-}, \mathrm{Mn}^{2+}, \mathrm{Fe}^{2+}, \mathrm{H}_{2} \mathrm{~S}$, and $\mathrm{S}$ ), which are a prerequisite substrate for autotrophic microbial processes (Table 6.1-1). Chemical analyses of groundwaters from Nye County Early Warning Detection Program wells show that the waters contain only trace amounts of dissolved iron (less than $2.34 \mathrm{ppm}$ ) and manganese (less than $0.58 \mathrm{ppm}$ ) (not necessarily all in $\mathrm{Fe}^{2+}$ and $\mathrm{Mn}^{2+}$ ), and $\mathrm{NH}_{4}^{+}$(less than $1 \mathrm{ppm}$ ) 
(DTN: GS011108312322.006 [DIRS 162911]). These waters were obtained from the saturated zone and thus provide an upper bound on the water in the unsaturated zone in terms of reduced inorganic species concentrations. Given the limited quantity of organic inputs (see Section 6.4.5), metals or metal alloys are the only major reducing components in the repository. Under oxidizing conditions, metal corrosion will not extensively generate reduced inorganic species, for instance, for iron corrosion:

$$
\mathrm{Fe}^{\mathrm{o}}+3 / 4 \mathrm{O}_{2}=1 / 2 \mathrm{Fe}_{2} \mathrm{O}_{3}
$$

$\mathrm{Fe}^{2+}$ ions may be present as an intermediate product of the above reaction, but they are transient in time and localized in space to the corrosion front. Long-term corrosion tests have been conducted to evaluate waste package material coupons in various solutions under anticipated repository conditions (Horn et al. 2003 [DIRS 167221]). Although deionized water was used in the composition of tank solutions, microorganisms were not purposefully excluded, and the tanks were not fully sealed from the surrounding laboratory environment. Therefore, these test tanks pose a somewhat analogous environment to the evolving repository. A differential staining and epifluorescence microscopic analysis indicated that microorganisms were present in testing tanks that contained acidic water, and in dilute and concentrated waters at $60^{\circ} \mathrm{C}$. With direct DNA extraction and characterization, three different microbial inhabitants were identified in simulated groundwater increased to 10 -fold ionic concentration and incubated at $60^{\circ} \mathrm{C}$ (Figure 6.4-3). Interestingly, even in this oligiotrophic and metallic alloy-dominated environment, the microbial population was dominated by hetrotrophic bacteria. Bacilli, known as heterotrophs, were observed to be the most numerous, representing 84 percent of the screened clones (Figure 6.4-3). This indicates that metal corrosion under Yucca Mountain-relevant conditions will not support any significant autotrophic microbial growth. This may be partly because abiotic $\mathrm{Fe}^{2+}$ oxidation is kinetically favored over microbial oxidation.

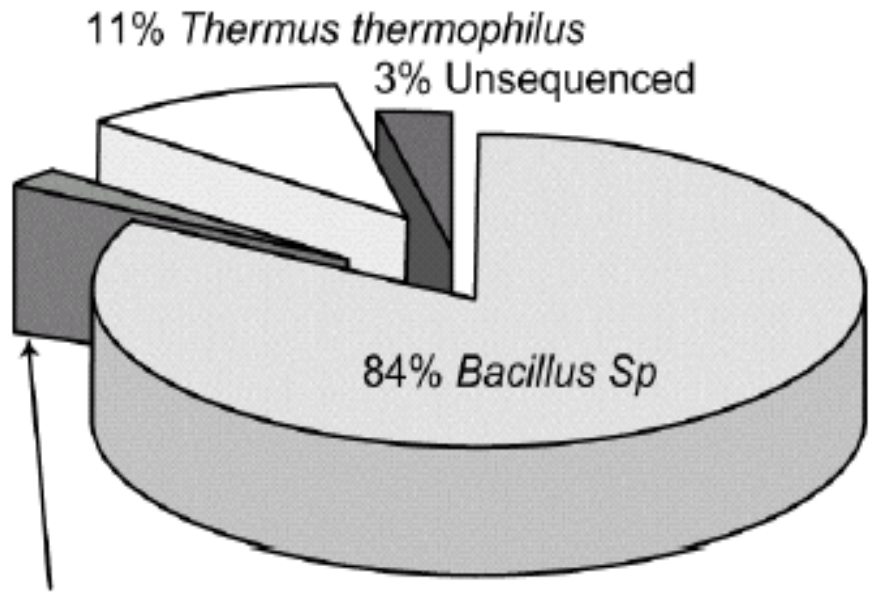

$2 \%$ Rubrobacter radiotolerans

Source: Horn et al. 2003 [DIRS 167221].

NOTE: After amplification and cloning of $16 \mathrm{~S}$ rDNA genes, 100 clones were screened; the frequency of occurrence of unique clone types is depicted as the percentage of the total number of screened clones.

Figure 6.4-3. Frequency of Unique Clone Types in a Long-Term Corrosion Tests Tank Containing Simulated $10 \mathrm{X}$ Groundwater at $60^{\circ} \mathrm{C}$ 


\subsubsection{Relative Humidity and Water Availability}

Water is essential for microbial growth (Table 4.1-4). The microbes found in unsaturated environments seem to be desiccation resistant (Kieft et al. 1993 [DIRS 100766]). Work done in several vadose zones at arid and semiarid sites indicates that the total numbers of microbes that are considered ambient range from $10^{4}$ to $10^{7}$ cells per gram dry weight (Kieft et al. 1993 [DIRS 100766]). It was also stated that, in the various vadose systems, there were many populations that were growth limited; most were growth limited by water or by organic carbon, but some systems were growth limited by nitrogen or by phosphorous (Kieft et al. 1993 [DIRS 100766]).

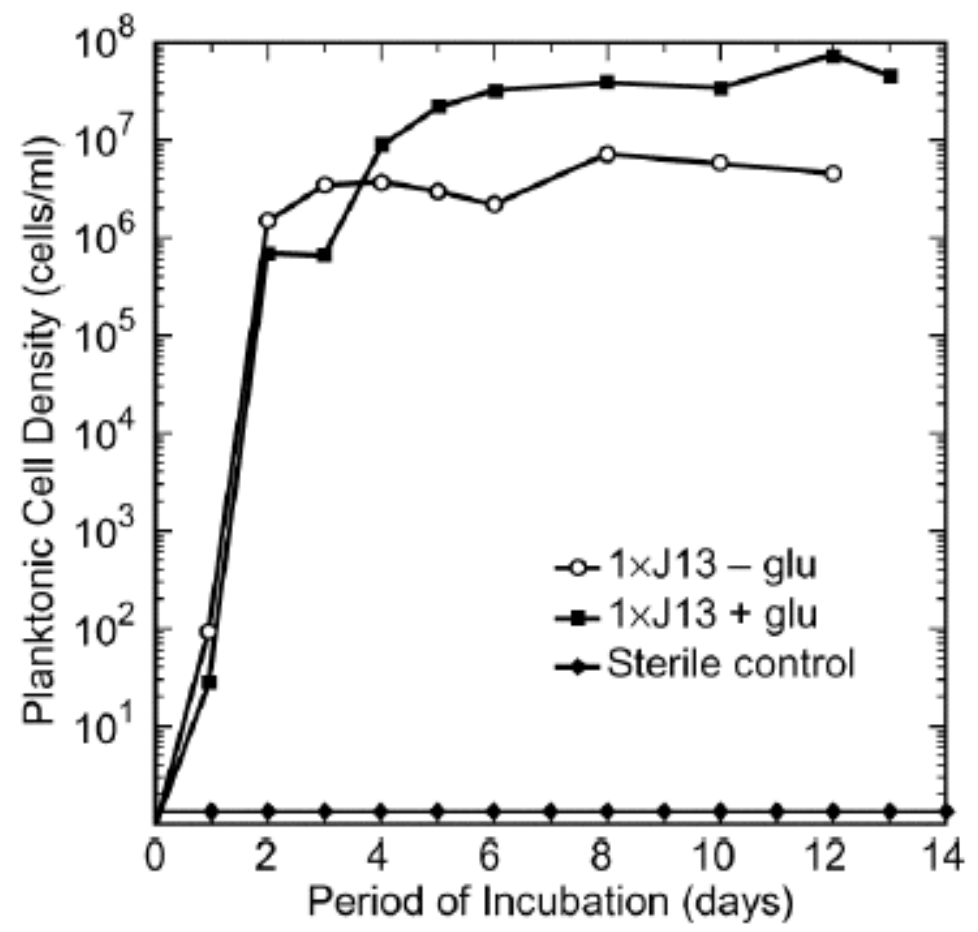

Source: DTN: LL040801512251.115 [DIRS 171476].

NOTE: Growth rates of Yucca Mountain aerobic bacteria in unconcentrated groundwater (1xJ13 Synthetic medium) with or without 0.1 percent glucose amendment, incubated under agitated batch conditions.

Figure 6.4-4. Growth Rates of Yucca Mountain Aerobic Bacteria in Unconcentrated Groundwater (1xJ13 Synthetic Medium) with and without Glucose Added

Observations of bacterial growth in unconcentrated groundwater provide evidence that sustainable population growth of microbial species requires significant quantities of liquid. Results of experiments conducted using a four to one ratio of simulated Yucca Mountain groundwater (1xJ13 Synthetic medium) to crushed rock sampled from relevant repository stratigraphic unit(s) are depicted in Figure 6.4-4, taken from Horn et al. (2004 [DIRS 171058], p. 280, Figure 4). J13 well water (DTN: MO0006J13WTRCM.000 [DIRS 151029]) has been extensively used as a representative groundwater for various modeling activities on Yucca Mountain (e.g., BSC 2004 [DIRS 169425]). 1xJ13 Synthetic medium used in the microbial 
growth experiments mimics the composition of inorganic compounds in actual J13 water. Three experimental conditions were tested: $1 \times \mathrm{xJ} 13$ with an added carbon source (glucose), without an added carbon source, and a sterile control sample. Both cultures using Yucca Mountain simulated groundwater attained stationary phase in three to four days of incubation (Horn et al. 2004 [DIRS 171058]. Between cultures that contained glucose and cultures that did not, stationary phase cell densities differed by approximately one order of magnitude. Without glucose amendment, maximal planktonic cell densities were approximately $4 \times 10^{6}$ cells $/ \mathrm{mL}$ to $8 \times 10^{6}$ cells $/ \mathrm{mL}$; with added glucose, cell densities were approximately $2 \times 10^{7}$ cells $/ \mathrm{mL}$ to $7 \times 10^{7}$ cells $/ \mathrm{mL}$. Only planktonic cell density, the number of cells suspended in water per $\mathrm{mL}$ of solution, was determined. Kieft et al. (1997 [DIRS 100767]) made a similar observation for microbes cultured from tuff collected in the ESF. The source of cellular carbon for growth of detected heterotrophs remains speculative; 1xJ13 Synthetic medium initially contained no organic carbon. The detected heterotrophs could be growing on dead and lysed cellular materials, or on volatile organic compounds (Horn et al. 2004 [DIRS 171058]). Also, in the experiment, only planktonic cell density, the number of cells suspended in water per $\mathrm{mL}$ of solution, was determined. The observed increase in planktonic cell density could be due to detachment of cells from crushed rock to liquids.

Water activity is ordinarily defined by the ratio of the solution vapor pressure to the vapor pressure of pure water at a given temperature. In order for microorganisms to grow, water activity needs to be 0.75 to 1.00 (Pedersen and Karlsson 1995 [DIRS 100810]; Brown 1976 [DIRS 118921]). Many bacteria perish, sporulate, or become dormant when water activity falls below approximately 0.90 (Brown 1976 [DIRS 118921]; Atlas and Bartha, 1981 [DIRS 118890], p. 154). Some fungi and yeast can be active at lower water activity levels (on the order of 0.7 to 0.85; see Pedersen and Karlsson 1995 [DIRS 100810]). However, these microorganisms have very small populations as compared to bacteria (Table 6.1-3) and are solely dependent on the availability of organic carbon, which is currently limited in the Yucca Mountain repository $(<1.1 \mathrm{ppm})$.

In a full-scale test conducted at Atomic Energy Canada Ltd. (AECL), a simulated waste container (maximum heat output $85^{\circ} \mathrm{C}$ ) was buried for 2.5 years, surrounded by compacted buffer materials. Extensive microbial analysis of this test has shown that most viable organisms in the buffer material disappear around a moisture content of 15 percent (corresponding to RH 95 to 96 percent) (Stroes-Gascoyne 1996 [DIRS 171851]).

The activity and availability of water for microbial growth in the UZ at Yucca Mountain will be dependent upon thermal-hydrologic conditions. The range of relative humidity (defined as water activity multiplied by 100) on all waste packages is shown in Figure 6.4-5. During the thermal pulse, relative humidity on the waste package surface can be lower than 10 percent. In some realizations, relative humidity recovers (back to 100 percent) after approximately 1,000 years. In many other realizations, relative humidity remains below 90 percent, and even below 70 percent in some cases, throughout the regulatory period, thus limiting microbial growth and activity. In addition, low water activity generally corresponds to low liquid-water availability (Figure 6.4-6). Low saturation of liquid water fractures on the drift wall will limit the transport growth substrates to microbial cells and, therefore, the activity of the cells. 


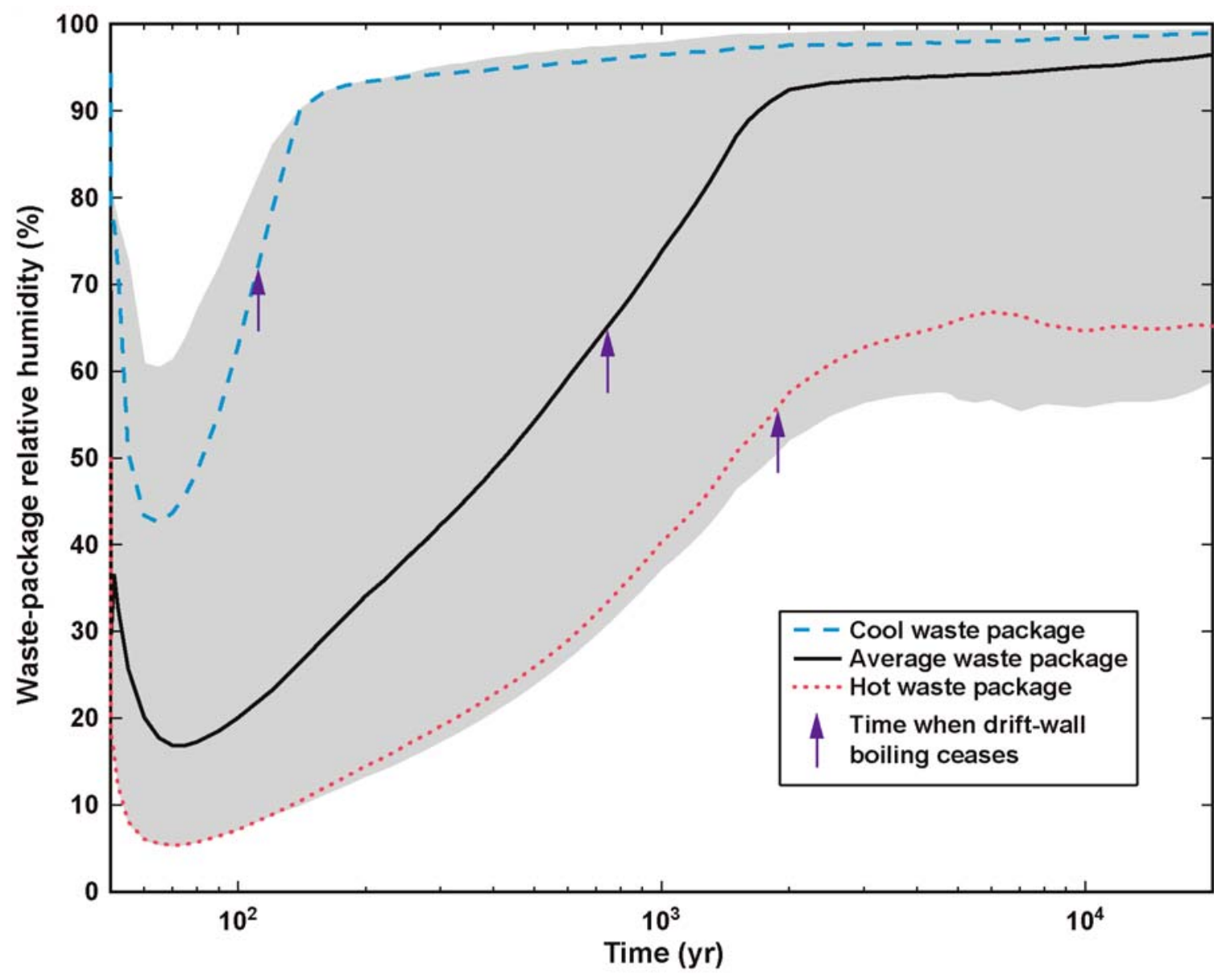

RHwp_his_3WPs_env

Source: BSC 2004 [DIRS 169565], Figure 6.3-68.

Figure 6.4-5. Range of Relative Humidity Histories for All Waste Packages, Accounting for Uncertainty of Host-Rock Thermal Conductivity and Percolation Flux 

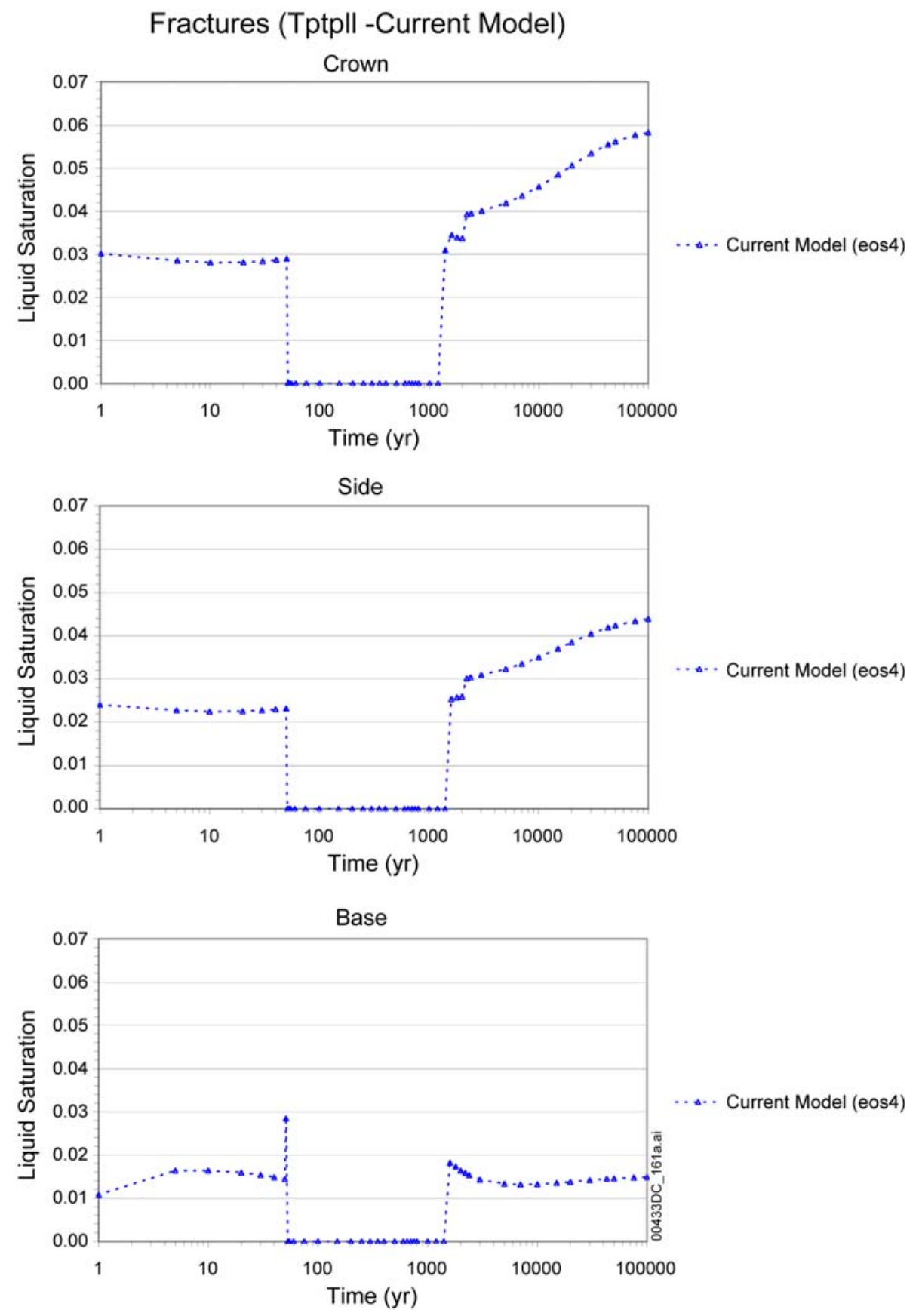

Source: BSC 2004 [DIRS 169856], Figure 6.5-6.

Figure 6.4-6. TH Simulation (Tptpll): Time Profiles of Modeled Liquid Saturations in Fractures at Three Drift-Wall Locations 


\subsection{4 pH and Salinity}

Bacteria grow over wide ranges of $\mathrm{pH}$, but there are limits to their tolerance (Amy and Haldeman 1997 [DIRS 100697]; Banfield and Nealson 1997 [DIRS 100703]; Pedersen and Karlsson 1995 [DIRS 100810]). Bacteria frequently change the $\mathrm{pH}$ of their own habitat by producing acidic or basic metabolic waste products. Most bacteria create their own habitats by forming biofilms. Each species of microbe has a $\mathrm{pH}$ growth range and growth optimum. Table 6.4-3 shows the types of microbes and their $\mathrm{pH}$ relationships. One natural analogue to alkaline groundwater comes from the natural springs in the Maqarin area in northwest Jordan, where the groundwaters have $\mathrm{pH}$ values as high as 12.9. These springs contain diverse microbial populations; therefore, the high alkalinity of the cementitious material and water in equilibrium with it will not preclude the growth of microorganisms (Pedersen 1999 [DIRS 110036]). The types of microorganisms residing in this environment would be alkalophiles and extreme alkalophiles. Where biofilms have been known to form on concretes, even the extreme alkaline $\mathrm{pH}$ environments will not preclude microbial colonization. Since cementitious materials are not used in ground support in the emplacement drifts, an extremely alkaline environment is not expected.

Table 6.4-3. Microbial Growth at Different pH

\begin{tabular}{|l|c|}
\hline \multicolumn{1}{|c|}{$\mathbf{p H}$} & pH Range \\
\hline Acidophiles & 1.0 to 5.5 \\
\hline Neutrophiles & 5.5 to 8.5 \\
\hline Alkalophiles & 8.5 to 11.5 \\
Extreme Alkalophiles & $>10.5$ \\
\hline
\end{tabular}

Source: Pedersen and Karlsson 1995 [DIRS 100810].

Bacteria can be affected by changes in the osmotic concentration of their surroundings (Madigan et al. 2003 [DIRS 171083]). However, some bacteria have adapted to extremely saline conditions, and can grow where there are high levels $(2.8$ to $6.8 \mathrm{M})$ of sodium chloride (Francis et al. 1997 [DIRS 171062]). Many bacteria are osmotolerant, and thrive in saline solutions that have concentrations of up to $3 \mathrm{M}$. Evaporation of seepage waters, or deliquescence of water on dust, in a low relative-humidity environment during the thermal pulse may result in concentrated brine solutions that have ionic strengths higher than 10 M (BSC 2004 [DIRS 169860], Figure 6.13-33), in which only a few halophilic bacteria can survive. Still, the activity of these bacteria will be limited after the thermal pulse, when a low ionic strength environment (close to the current environment) is reestablished. The current ionic strength of Yucca Mountain pore water is typically much less than $1 \mathrm{M}$ (DTN: GS011108312322.006 [DIRS 162911]).

\subsubsection{Inputs of Nutrients}

This section addresses the impacts of microbial activity on two FEPs:

1. FEP 1.1.02.00.0A (chemical effects of excavation/construction in EBS)

2. FEP 2.1.06.01.0A (chemical effects of rock reinforcement and cementitious materials). 
In addition to the presence of water, the other major necessity for microbial life is the environmental presence of a few major nutritional elements: carbon, nitrogen, sulfur, and phosphorous). These elements, the chief building blocks of a microbe, can derive from four sources: ambient rock, groundwater flow, gas flow, and introduced materials.

Experiments have been performed to define conducive and inhibitory environmental conditions that pertain to growth of Yucca Mountain microbial communities in modified Yucca Mountain groundwater. Specifically, these experiments were designed to determine whether individual macronutrient (i.e., nitrogen, sulfate, phosphate, and carbon) concentrations extant in Yucca Mountain groundwater would support microbial growth in Yucca Mountain, and to determine growth rates and stationary phase microbial densities under aerobic, saturated conditions.

Experimental data (Figure 6.4-7) show that nitrogen and sulfate sources are apparently sufficient to support microbial growth, even in unconcentrated Yucca Mountain groundwater. Nitrogen is often incorporated into cellular metabolism by reducing nitrate to ammonia that can then be utilized by various biosynthetic pathways. Limited numbers of bacterial species are able to reduce and assimilate atmospheric nitrogen. Most bacterial species use sulfate as a source of sulfur, and reduce it by assimilatory reduction. Sulfate is available in groundwater; it is not usually a limiting nutrient.

Next in importance after water availability, according to the relative effect on increasing cell density, is phosphate availability, which increased cell densities approximately 1.5 orders of magnitude (Figure 6.4-7). The addition of a carbon source, glucose, had the least effect on increasing maximal cell densities; it only resulted in increases of one order of magnitude in unconcentrated simulated groundwater medium (1xJ13 Synthetic) (Figure 6.4-4). Yucca Mountain groundwater has extremely low levels of organic carbon and phosphate (DTN: GS011108312322.006 [DIRS 162911]). Except when it was added exogenously, the only source of phosphorous available to the Yucca Mountain organisms growing from crushed rock in these studies was the Yucca Mountain tuff, which reportedly contains from 0.01 to 0.02 weight percent (100 to $200 \mathrm{ppm}$ ) of phosphorous (DTN: LL981209705924.059 [DIRS 110317]). Phosphate was also introduced into the ESF by construction activities. Microorganisms are well known to solubilize phosphate through the production of acids and a variety of other well-characterized mechanisms (Ehrlich 1996 [DIRS 119001]). Therefore, mineralogical or introduced phosphate in Yucca Mountain tuff will be the major source of phosphate to support cellular growth.

Only trace concentrations of organic carbon (up to $1.1 \mathrm{mg} / \mathrm{L}$ ) have been reported in qualified measurements of Yucca Mountain groundwater (DTN: GS011108312322.006 [DIRS 162911]). Even without the addition of glucose to experimental growth media, however, significant heterotrophic microbial growth was observed (Figure 6.4-4), and few isolates that were enumerated and identified from unconcentrated simulated groundwater without glucose had autotrophic capabilities (Table 6.3-1); the source of cellular carbon for growth of detected heterotrophs is, therefore, unknown. 
(Panel A)

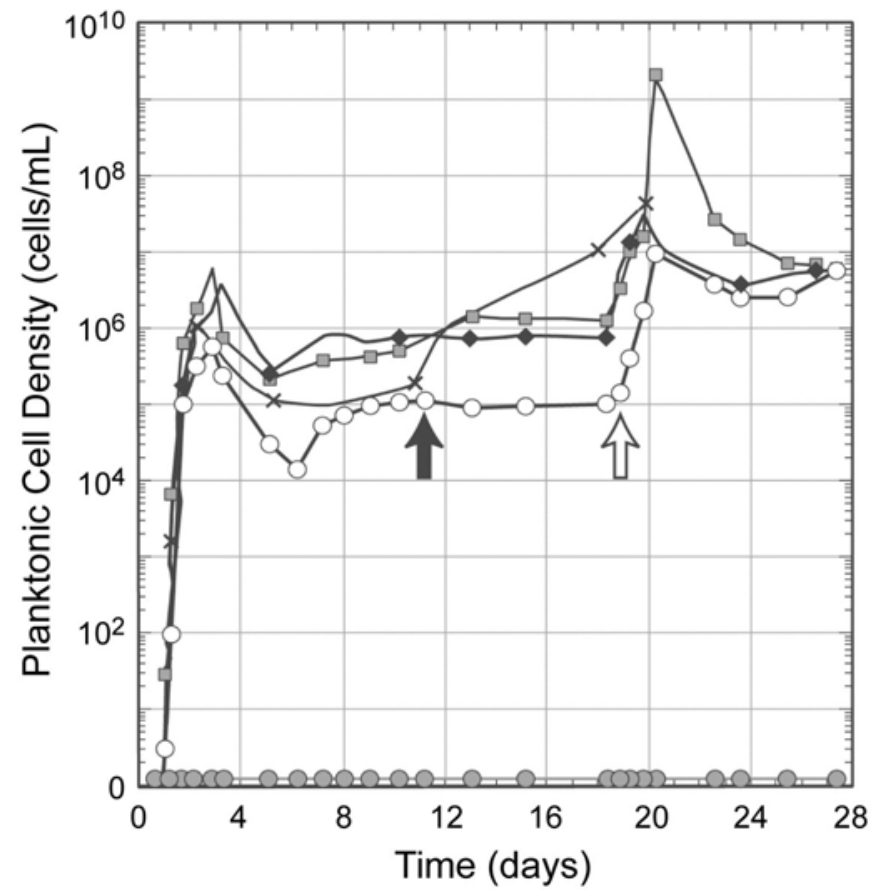

(Panel B)

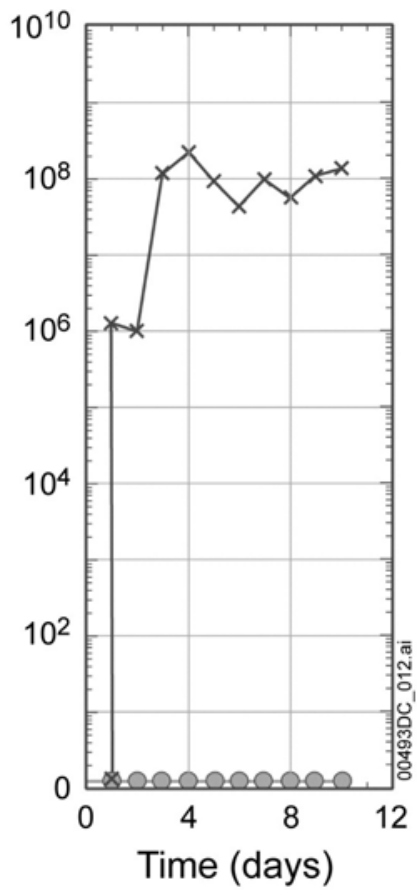

Source: Horn 2004 [DIRS 171476].

NOTES: Growth rates of Yucca Mountain culturable aerobic bacteria as a function of macronutrient concentrations found in 10xJ13 Synthetic and derivative media which had increased levels of individual macronutrients. $10 \mathrm{xJ} 13$ Synthetic medium is a concentrated (by a factor of 10 ) synthetic J13 water, which contains 5.55 $\mathrm{mM}$ glucose and $0 \mathrm{mM}$ phosphate.

Panel A: Continuously fed microcosm reactors. Panel B: Unreplenished, agitated batch systems.

Filled arrow designates the time at which $10 \mathrm{mM}$ sodium phosphate was added to 10xJ13 Synthetic culture. Unfilled arrow designates the time at which sodium phosphate was added to all other culture media. Results shown are those of a single, representative trial.

$$
\text { Legend: } \quad \begin{aligned}
\times & =10 \times \mathrm{J} 13 \text { Synthetic } \\
& =10 \times \mathrm{J} 13 \text { Synthetic }+\mathrm{SO}_{4} \\
\mathrm{O} & =10 \times \mathrm{J} 13 \text { Synthetic }+\mathrm{NO}_{3} \\
& =10 \times \mathrm{J} 13 \text { Synthetic }+\mathrm{SO}_{4}+\mathrm{NO}_{3} \\
& =\text { Sterilized rock and } 10 \times \mathrm{J} 13 \text { Synthetic }+\mathrm{SO}_{4}+\mathrm{NO}_{3}
\end{aligned}
$$

Figure 6.4-7. Growth of Yucca Mountain Culturable Aerobic Bacteria as a Function of Macronutrient Concentration in Yucca Mountain

Organic carbon concentrations in Yucca Mountain groundwater are low. Most groundwaters that are not affected by pollution have dissolved organic carbon concentrations of zero to $2 \mathrm{mg} / \mathrm{L}$ (Drever 1997 [DIRS 140067], p. 118). The dissolved organic carbon of shallow groundwaters generally comes from surface organic matter composed of soil and plant humic matter; in deeper groundwaters (100 $\mathrm{m}$ and deeper), the source of dissolved organic carbon is the microbial degradation of kerogen, the fossilized organic matter that is present in the geological material of the aquifer. Means (1982 [DIRS 171136]) analyzed deep aquifer samples (collected from Sterno and Stripa mines in Sweden, and from Hanford, Washington, USA) for organic compounds. Several phenols, organic acids, low-MW fulvic acids, hydrocarbons, aldehydes, and alcohols have been identified. 
The materials introduced into emplacement drifts will not contain any organic carbon (BSC 2004 [DIRS 170058]), except for a trace amount of reduced carbon in metal or metal alloys. These carbons, like graphite, are expected to be refractory and thus will not be biodegradable. Therefore, the reduced carbon in the introduced materials is not expected to be available for microbial reactions.

In summary, organic carbon is an important limiting factor for Yucca Mountain microbial growth. The extremely low organic-carbon supply in the repository will limit heterotrophic microbial activity.

\subsubsection{Biofilm Formation}

After attachment to surfaces, microbes initiate production of slimy adhesive substances, generally exopolysaccharides. These extracellular polymers, which frequently extend from the cell to form a tangled matrix of fibers, provide structure to the microbial assemblage. This structure is normally termed a biofilm. Microorganisms within biofilms are capable of maintaining unique environments at biofilm/surface interfaces (both liquid-solid and gas-liquid interfaces) that are radically different from the bulk in terms of $\mathrm{pH}$, dissolved oxygen, and other organic and inorganic species (Little et al. 1997 [DIRS 100774]). Microorganisms that carry out MIC can occur in, and are facilitated by, biofilms.

Else et al. (2003 [DIRS 168172]) studied the effects of relative humidity and temperature on the attachment of microbial cells to metal surfaces. Mined Yucca Mountain tuff was collected near the North Portal entrance. Flame-sterilized tools were used to remove the surface layer of the tunnel wall, and the newly exposed rock was put into sterile plastic bags and placed on ice. Flame-sterilized mortars and pestles were used to aseptically crush the rock into fine grains. One-centimeter-square coupons were constructed from the following metals: C22 nickel alloy (Alloy 22), N-316 stainless steel, and titanium. Aseptically crushed rock was transferred to sterile glass petri plates, metal coupons were placed within the crushed rock, and microcosms were placed in chambers held to specific relative humidity and temperature values. Microcosms were equilibrated for 1 week prior to the addition of metal coupons. At designated time points, adherent materials were scraped off coupons and homogenized by vortexing in $1.0 \mathrm{~mL}$ of R2 broth. Homogenized materials $(100 \mu \mathrm{l})$ were plated onto R2A agar, and were incubated at room temperature $\left(25^{\circ} \mathrm{C}\right)$ for 2 weeks. Colony-forming units (CFUs) were counted. Note that only heterotrophs would be detected on R2A.

From day 0 to day 1 , at 100 -percent relative humidity and $30^{\circ} \mathrm{C}$, the heterotrophic plate count (HPC) values from the three metal types increased from less than $1 \times 10^{2}$ to a range of $2 \times 10^{4}$ to $4 \times 10^{4}$ CFU per coupon (Else et al. 2003 [DIRS 168172]). All three metal types supported increased HPC values by 5 months $\left(4 \times 10^{4}\right.$ to $7 \times 10^{4}$ CFU per coupon); however, after 18 months of incubation fewer microbes were cultured $\left(5 \times 10^{2}\right.$ to $8 \times 10^{2}$ CFU per coupon). After day 0, HPC values at 84-percent relative humidity were lower than at 100-percent relative humidity for all three metal types. Although there was attachment of microorganisms (approximately $2 \times 10^{2} \mathrm{CFU}$ per coupon at day 1 for all three-coupon types), it was followed by stable to decreasing values until 18 months of incubation, after which HPC values nearly equaled the 18-month value at 100-percent relative humidity. At 70.5-percent relative humidity, HPC values consistently decreased, from slightly less than $10^{2}$ CFU per coupon at day 0 , for the 
remainder of the test. At 32-percent relative humidity, N-316 coupons demonstrated microbial attachment, $10^{2} \mathrm{CFU}$ per coupon at day 0 , which gradually increased and then remained stable during the remainder of the experiment. Titanium coupons showed microbial attachment, less than $10^{2} \mathrm{CFU}$ per coupon at day 0 , with an increase in CFU values to almost $10^{3} \mathrm{CFU}$ per coupon after 5 months of incubation; however, by 12 to 18 months of incubation, CFU values decreased by 10 -fold, to near their original level. For C22 nickel alloy, the HPC values increased from day 0 , with a peak at 5 months, followed by a decrease in cell number to $10^{2} \mathrm{CFU}$ per coupon. The data indicate the complexity of the dependence of microbial attachment on relative humidity. When viewed by SEM, the attached cells, including heterotrophs and autotrophs, only formed small clusters, and there was no continuous-biofilm formation.

At $60^{\circ} \mathrm{C}$ and $70^{\circ} \mathrm{C}$, HPC values decreased, for all three coupon types, from less than $10^{2} \mathrm{CFU}$ per coupon to undetectable levels at day 1 , and then remained undetectable for the duration of the test, with the exception of detectable values at 1 and 5 months of incubation in each case. The difference in $\mathrm{HPC}$ values at $60^{\circ} \mathrm{C}$ and $70^{\circ} \mathrm{C}$ is significant in comparison to those at $30^{\circ} \mathrm{C}$. Microbial attachment was negligible compared to that at $30^{\circ} \mathrm{C}$, as evidenced by scanning electron microscope (SEM) on all three coupon types. Cell attachment might have been limited not only by elevated temperature, but by individual microbial ability to produce extracellular polymeric substances (EPS). Temperature may have had an effect on the production of EPS, which is known to enhance the adherence capability of microbial cells. SEM studies have shown that Listeria monocytogenes cells produced an EPS matrix at $21^{\circ} \mathrm{C}$, but not at $10^{\circ} \mathrm{C}$ or $35^{\circ} \mathrm{C}$ (Norwood and Gilmour 2001 [DIRS 171133]). EPS is critical not only for initial adhesion, but for the firm anchorage of bacteria to solid surfaces (Norwood and Gilmour 2001 [DIRS 171133]), and to the ability of biofilm microorganisms to deal with environmental stresses, such as nutrient limitations, solar radiation, and variations in temperature (Perrot et al. 1998 [DIRS 171124]).

In summary, increased temperature (to $60^{\circ} \mathrm{C}$ or $70^{\circ} \mathrm{C}$ ) or decreased relative humidity (values below 100 percent) impeded biofilm formation on N-316 stainless steel, C22 nickel alloy, and titanium coupon surfaces. In the repository, where temperatures will be maintained above $50^{\circ} \mathrm{C}$ (Figure 6.4-1), and the supply of water and nutrients will be limited, the formation of biofilm will be limited. This is consistent with a report that under unsaturated conditions of soil and vadose rock, extensive biofilm development has not been observed (Auerbach et al. 2000 [DIRS 171116]). This is also consistent with a full-scale test conducted by AECL, in which a simulated waste container was buried for 2.5 years surrounded by a compacted buffer material. The test showed that, together, decreased relative humidity (95 to 96 percent), elevated temperature $\left(60^{\circ} \mathrm{C}\right.$ to $\left.90^{\circ} \mathrm{C}\right)$, high radiation doses, and limited nutrient supplies prevented biofilm formation (Stroes-Gascoyne 1996 [DIRS 171851]).

\subsubsection{Radiation Effect}

Microorganisms, in general, are tolerant or resistant to ionizing radiation. Much of the information on the radiation resistance of microorganisms comes from the food industry, because ionizing radiation is used in many countries as a means of preserving foods. Exposing foods to low doses of ionizing radiation (less than $1 \mathrm{Mrad}$ ) substantially reduces the number of those microorganisms responsible for food spoilage, thereby extending the shelf life of the food. Gamma radiation has also been used to disinfect and treat wastewater effluents. 
Many radioresistant strains of bacteria have been isolated from soil, and studies of soil microflora irradiated with long-term $\gamma$-radiation (in an open-air facility at 15, 150, 800, and $1500 \mathrm{krad}$ over 18 months) showed that radiation resistance increased at all doses (Table 6.4-4) when compared with the radiation resistance of soil microflora from soil shielded from irradiation with lead bricks (Eriksen and Emborg 1978 [DIRS 171113]). Barnhart et al. (1980 [DIRS 171112]) found that approximately 68 percent of the microbial isolates from radioactive shallow land burial site soil exhibited greater resistance to $\gamma$-and $\beta$-radioactivity than did the common soil bacterium Bacillus subtilis to ionizing radiation. Approximately 25 percent of the isolates from nonradioactive soil were more resistant than $B$. subtilis, but all these microbial isolates were less radioresistant than Deinococcus radiodurans, which is resistant to $\gamma$-radiation $\left(10^{5} \mathrm{rad}\right)$. However, radio-resistant bacteria are constantly being enriched in an environment containing nanocurie levels of $\gamma$ - and $\beta$-radioactivity (Barnhart et al. 1980 [DIRS 171112]). In the later study, the radio-resistance of 10 isolates of bacteria from a soil core (of a $40-\mathrm{cm}$ to $50-\mathrm{cm}$ depth, and containing $20 \mathrm{nCi}$ to $30 \mathrm{nCi}$ of radioactivity), taken from a shallow land burial site at Los Alamos National Laboratory, was studied. Several of the isolates were resistant to $5 \times 10^{4} \mathrm{rad} \gamma$-radiation. At $7.5 \times 10^{4} \mathrm{rad}$, none of the isolates survived. Radiation resistance of bacteria, with reference to the studies dealing with radioactive waste, is shown in Table 6.4-5. These data are in good agreement with the values reported from sewage, food, and sterilization processes in the literature.

Table 6.4-4. Radioresistance of Soil Microorganisms Previously Exposed to Long-Term y-Irradiation (Expressed as a Percentage of Tubes with Visible Growth)

\begin{tabular}{|l|c|c|c|c|}
\hline \multirow{2}{*}{$\begin{array}{l}\text { Soil Sample Previously } \\
\text { Exposed to Y-Radiation } \\
\text { (krad/18 months) }\end{array}$} & \multicolumn{4}{|c|}{ Irradiation dose (Mrad) } \\
\cline { 2 - 5 } & $\mathbf{2}$ & $\mathbf{3}$ & $\mathbf{4}$ & $\mathbf{5}$ \\
\hline 0 (Control) & 100 & 47 & 0 & 0 \\
\hline 15 & 100 & 93 & 3 & 0 \\
\hline 150 & 100 & 100 & 100 & 0 \\
\hline 800 & 100 & 100 & 40 & 7 \\
\hline 1500 & 100 & 100 & 100 & 4 \\
\hline
\end{tabular}

Source: Erikson and Emborg 1978 [DIRS 171113].

Table 6.4-5. Gamma Radiation Resistance of Bacteria Isolated from Various Sources

\begin{tabular}{|l|c|l|}
\hline \multicolumn{1}{|c|}{ Organism/Source } & Radiation dose (rad) & \multicolumn{1}{c|}{ Reference } \\
\hline $\begin{array}{l}\text { Deinoccocus radiodurans (ATCC 13939) } \\
\text { (wet) }\end{array}$ & $10^{5}$ & Barnhart et al. 1980 [DIRS 171112] \\
\hline $\begin{array}{l}\text { Deinoccocus radiodurans (ATCC 13939) } \\
\text { (dry) }\end{array}$ & $2.4 \times 10^{6}$ & Barnhart et al. 1980 [DIRS 171112] \\
\hline Bacillus subtilis (ATCC 6051) & $<2.5 \times 10^{5}$ & Barnhart et al. 1980 [DIRS 171112] \\
\hline $\begin{array}{l}\text { Microbial isolate QB2 from BNL reactor spent } \\
\text { resin (wet) }\end{array}$ & $10^{4}$ & Francis and Quinby 1981 [DIRS 171114] \\
\hline $\begin{array}{l}\text { Strain K.3.24 and K.3.25 from control soil } \\
\text { (dry) }\end{array}$ & $1.5 \times 10^{6} ; 2.25 \times 10^{6}$ & Erikson and Emborg 1978 [DIRS 171113] \\
\hline $\begin{array}{l}\text { Strain 30.5.11 and 30.5.16 from irradiated soil } \\
\text { (dry) }\end{array}$ & $5 \times 10^{6} ; 8 \times 10^{6}$ & Erikson and Emborg 1978 [DIRS 171113] \\
\hline $\begin{array}{l}\text { Several isolated from radioactive waste } \\
\text { disposal sites }\end{array}$ & $5 \times 10^{6} ; 8 \times 10^{6}$ & Erikson and Emborg 1978 [DIRS 171113] \\
\hline
\end{tabular}


A time-course experiment was conducted to evaluate the effects of $\gamma$-radiation on the indigenous microbiota present in rock obtained from Yucca Mountain and the Nevada Test Site (Pitonzo et al. 1999 [DIRS 150442]). Microcosms were constructed by placing pulverized Yucca Mountain rock in polystyrene cylinders. Continuous exposure $(96 \mathrm{~h})$ at a dose rate of $1.63 \mathrm{Gray}(\mathrm{Gy}) / \mathrm{min}$ was used to mimic the near-field environment surrounding waste canisters. The microbial communities were characterized after receiving cumulative doses of $0 \mathrm{kGy}, 0.098 \mathrm{kGy}$, $0.58 \mathrm{kGy}, 2.33 \mathrm{kGy}, 4.67 \mathrm{kGy}, 7.01 \mathrm{kGy}$, and $9.34 \mathrm{kGy}$. Radiation-resistant microorganisms in the pulverized rock became viable but nonculturable (VBNC) after a cumulative dose of $2.33 \mathrm{kGy}$. VBNC microorganisms lose the ability to grow (on media on which they have routinely been cultured) in response to the environmental stress imposed (i.e., radiation), but can be detected throughout the time course by means of direct fluorescence microscopy techniques. Two representative exopolysaccharide-producing isolates from Yucca Mountain were exposed to the same radiation regimen in sand microcosms. One isolate was much more radiation-resistant than the other, but based on culturable counts both had greater resistance than the general microbial community. However, when respiring cell counts (using only VBNC) were compared after irradiation, the results would indicate much more radiation resistance of the individual isolates and the microbial community in general. These results have significant implications for underground storage of nuclear waste, because they indicate that indigenous microorganisms are capable of surviving $\gamma$-irradiation in a VBNC state.

To further investigate the VBNC bacteria, portions of irradiated rock were placed at $4^{\circ} \mathrm{C}$ for 2 months, in an attempt to resuscitate the microbes to a culturable state (Pitonzo et al. 1999 [DIRS 150442]). Culturable heterotrophs were enumerated, and BIOLOG plates were used to determine the metabolic capability of the microbial community. Culturable bacteria that had previously been nonculturable were found at all doses. The number of colony types decreased from 26 in the nonirradiated control rock to between 9 and 10 in rock irradiated at doses ranging from $2.34 \mathrm{kGy}$ to $9.34 \mathrm{kGy}$. BIOLOG plates indicated partial recovery of metabolic capacity in all tested samples. Using the MIDI system (Microbial ID, Inc.), fatty acid methyl ester analysis of the recovered isolates yielded three distinct groups of related bacteria. All resuscitated isolates clustered with the original nonirradiated isolates at the genus level, and 92 percent of them clustered at the species level. These results indicated that microbes were probably resuscitated from a VBNC state.

Based on the current repository loading design, the expected maximum surface dose rate from one unbreached canister designed to contain spent nuclear fuels is:

$0.06 \mathrm{~Gy} / \mathrm{min}(=31.5 \mathrm{kGy} / \mathrm{yr}=3.15 \mathrm{Mrad} / \mathrm{yr}) \quad($ conversion: $1 \mathrm{kGy}=0.1 \mathrm{Mrad})$ (Pitonzo et al. 1999 [DIRS 150442]).

By comparison with the radiation dose resistance values listed in Table 6.4-7 and Table 6.4-8, it is expected that radiation may inhibit microbial growth in the repository. This assessment is consistent with an AECL test that used a simulated waste container with a maximum heat output of $85^{\circ} \mathrm{C}$ ). The test has shown that the surface of a nuclear fuel waste container is "sterilized" 9 to 33 days after emplacement (Stroes-Gascoyne 1996 [DIRS 171851]). 


\subsection{POTENTIAL IMPACTS ON REPOSITORY CHEMISTRY}

Together, the subsections of Section 6.5 address the impacts of microbial activity on two FEPs:

1. FEP 2.1.09.01.0A (chemical characteristics of water in drifts)

2. FEP 2.1.09.02.0A (chemical interaction with corrosion products).

Section 6.5.1 also addresses the impact of microbial activity on FEP 2.1.12.01.0A (gas generation [repository pressurization]).

Microbial growth and activity at Yucca Mountain are limited by multiple factors: elevated temperatures, oxic environments, low relative humidity, high water salinity, limited nutrient supplies, and high radiation fields (see Section 6.4). Given these environmental constraints, the upper bound of microbial cell density in the repository can be constrained as follows:

- Cell density in the surrounding rocks: Because the perturbation of waste emplacement in the drift (e.g., elevated temperatures, low relative humidity, and high radiation field) will lead to a near-field environment less conducive to microbial growth, and because metal corrosion under the anticipated repository conditions will not be able support any significant autotrophic microbial growth (Section 6.4.2), the upper limit of microbial population in the surrounding rocks can be set to $5 \times 10^{5}$ cells/g dry rock throughout the regulatory time period. This value bounds all reported values (Section 6.3).

- Suspended cell density in water: No field measurements are available for suspended cell density in Yucca Mountain underground water. The upper limits of this cell density can be constrained from Yucca Mountain-related microbial incubation experiments. The results of the most relevant experiments are shown in Figure 6.4-4. In these experiments, tuff rocks were incubated with simulated J13 water amended with or without glucose. As shown in the figure, a significant microbial growth was stimulated by the addition of an organic source. Because the concentration of glucose in the growth solution was as high as $5.55 \mathrm{mM}$, which was about 55 times higher than the maximum organic carbon concentration $(1.1 \mathrm{mg} / \mathrm{L}=0.1 \mathrm{mM})$ in Yucca Mountain groundwaters, the planktonic cell density $\left(7 \times 10^{7}\right.$ cells $\left./ \mathrm{mL}\right)$ measured in the organic-carbon-amended experiment thus provides a reasonable upper bound on the suspended cell density in the in-drift water throughout the regulatory period.

\subsubsection{Water Chemistry $\left(\mathrm{pH}, \Sigma \mathrm{CO}_{2}\right)$}

Heterotrophic degradation of organic carbon will release $\mathrm{CO}_{2}$ as a metabolic product. For example, in an aerobic environment:

$$
\mathrm{CH}_{2} \mathrm{O}+\mathrm{O}_{2}=\mathrm{CO}_{2}+\mathrm{H}_{2} \mathrm{O}
$$

The release of carbon dioxide could potentially perturb the carbonate equilibrium and therefore the $\mathrm{pH}$ in water entering the repository. The extent of this perturbation solely depends on the availability of organic carbon, which can derive from two sources: groundwater and introduced materials. 
According to the current repository design, the committed construction materials will contain no biodegradable organic carbon (see Table 4.1-1). Yucca Mountain groundwater contains only a trace concentration of organic carbon $(1.1 \mathrm{mg} / \mathrm{L})$ (Table 4.1-1), which is much lower than the total carbonate concentration (41 to $430 \mathrm{mg} / \mathrm{L}$ ) in the solution (DTN: GS011108312322.006 [DIRS 162911]). Therefore, even if all the dissolved organic carbon is converted to carbon dioxide, the perturbation to the water chemistry is still negligible:

$$
\left(<\frac{1.1 \mathrm{mg} \mathrm{C} / \mathrm{mL}}{12 \mathrm{~g} \mathrm{C} / \mathrm{molC}} \div \frac{41 \mathrm{mg} \text { bicarbonate } / \mathrm{mL}}{61 \mathrm{~g} \text { carbonate } / \mathrm{mol} \mathrm{C}}=14 \%\right)
$$

Additional organic substances (e.g., diesel fuel, diesel exhaust, lubricants, rock drill oil, coolants and cleaning solvents) may be introduced into the repository during construction and operations. The quantities and types of such substances are currently controlled, with analysis of the potential impacts to waste isolation (BSC 2004 [DIRS 169885], Section 6.12.3); LP-SA-001Q-BSC). Thus, the total quantity of such substances committed in the repository will be limited (see Section 5, Assumptions).

These substances will tend to be removed with the waste rock during construction, or dispersed by construction water into the host rock. Elevated temperature and ventilation during preclosure operations will also disperse volatile organic compounds. Furthermore, degradation of residual organic material in the drift will have limited effect on the bulk chemical environment, which is demonstrated by a simple example. As shown in Figure 6.5-1, carbon dioxide in the drift will be continuously circulated by gas flow after repository closure, due to thermal-hydrologic-chemical processes in the host rock, with a flux greater than 0.1 mole $\mathrm{CO}_{2}$ per year per meter of drift. This gas flux is sufficient to dissipate the $\mathrm{CO}_{2}$ generated from complete conversion of at least 1.4 grams of diesel fuel $(=0.1 / 8 *(8 * 12+18) \mathrm{g})$ using $\mathrm{C}_{8} \mathrm{H}_{18}$ as a representative formula) over one meter drift within a year, without significantly changing the $\mathrm{CO}_{2}$ abundance in the emplacement drifts. Therefore, small quantities of organic substances will have an insignificant effect on the bulk chemical environment in the drifts. Potential microbial effects on radionuclide transport (e.g., associated with microbial degradation of organic carbon in the invert) are discussed in Section 6.5.4. 


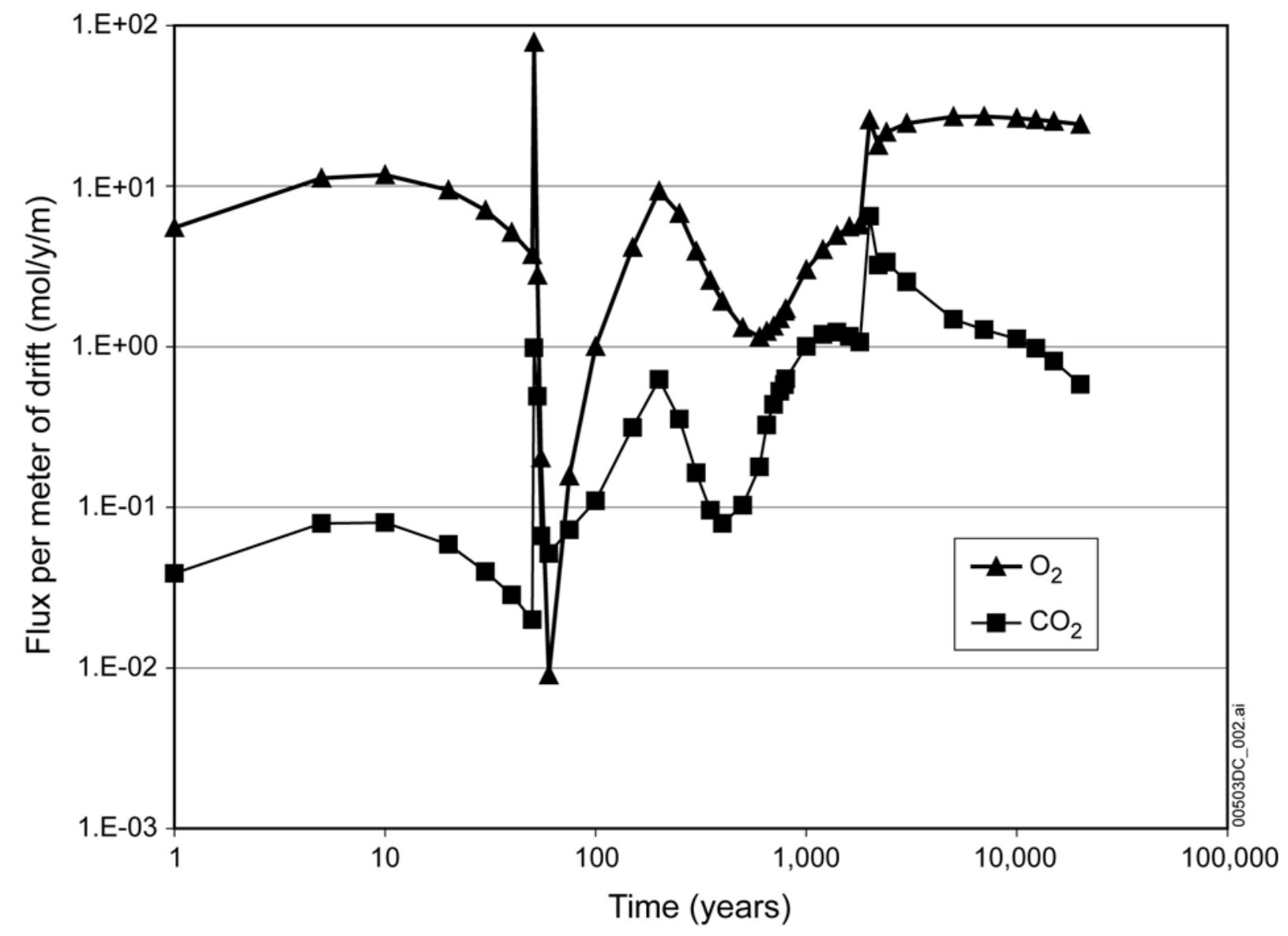

Source: DTN: SN0407T0510102.017 [DIRS 170667], file: gas_flux.xIs, worksheet: moles per m chart.

Figure 6.5-1. $\mathrm{CO}_{2}$ Flux Calculated from a Cumulative Gas Flux Predicted by the THC Model

\subsubsection{Low Molecular-Weight Organic Ligands}

Microorganisms also perturb the geochemical speciation of radionuclides by releasing (into the surrounding extracellular environment) organic chemicals as by-products of metabolism (Stone 1997 [DIRS 110045]). These chemicals contain a variety of functional groups that may complex with radionuclides. Two groups of microbial compounds are considered complexing agents:

- By-products of microbial metabolism and degradation

- Microbial exudates.

The first group consists of simple organic compounds such as low-MW organic acids. The second group includes microbial exudates induced by metals ions. Iron-binding siderophores are produced in response to low iron concentrations. 
Table 6.5-1. Microbial Production of Low-MW Organic Acids Detected in the WIPP Microbial Gas-Generation Experiments

\begin{tabular}{|l|c|c|c|}
\hline \multicolumn{1}{|c|}{ Experimental Condition } & Formate (M) & Acetate (M) & Lactate (M) \\
\hline Cellulose + cells + no nutrients & $9.99 \times 10^{-04}$ & $2.01 \times 10^{-03}$ & $8.88 \times 10^{-05}$ \\
\hline Cellulose + cells + nutrients & $2.90 \times 10^{-03}$ & $4.45 \times 10^{-03}$ & $6.88 \times 10^{-04}$ \\
\hline Cellulose + cells + nutrients + extra nitrate & $3.92 \times 10^{-03}$ & $4.43 \times 10^{-03}$ & $1.57 \times 10^{-03}$ \\
\hline
\end{tabular}

Source: Francis et al. 1997 [DIRS 171062].

NOTE: The measurements were performed at 1,228 days after inoculation with cellulose materials.

Depending on the types of organic materials introduced into the repository and the environmental conditions, there could be variable abundances of the small MW complexing agents. These low-molecular organic acids, released as intermediate metabolites, are also subjected to additional microbial degradation. Thus, the concentrations of these organic compounds are limited in natural systems. For example, in the Middendorf aquifer of South Carolina, the concentration of acetate was in the range of 0.5 to $3 \mu \mathrm{M}$; the concentration of formate was in the range of $0 \mu \mathrm{M}$ to $15 \mu \mathrm{M}$ (Chapelle 2001 [DIRS 171162], p. 179). It was also observed that the concentration of formate increased in the iron-rich zone of the aquifer. In a system extremely rich in organic carbon and nutrients, the concentrations of these organic acids can be higher. In experiments incubating cellulose materials with the WIPP-related bacteria, the concentrations of formate, acetate, and lactate could be up to a few $\mathrm{mM}$, especially in those amended with extra nitrate (Table 6.5-1) (Francis et al. 1997 [DIRS 171062]).

The repository is an extremely oligotrophic environment, in which microbial activity is limited. The concentration of the microbially generated organic acids, if there are any, should be low. Concentration for any organic ligands present should be lower than the values reported for the Middendorf aquifer ( 0 to $15 \mu \mathrm{M}$ for each ligand present), which is located in organic-carbon-rich sedimentary rocks. To evaluate the capability of these organic acids for metal complexation, a conservative upper bounding concentration of $50 \mu \mathrm{M}$ for each ligand is chosen. The fraction of a radionuclide complexed by an organic acid can be calculated by considering formation constants of metal complexes as described by Dean (1992 [DIRS 100722], Section 8.2.2). For a reaction stoichiometry written as:

$$
R+C=R C
$$

where $R$ is a metal (or radionuclide) and $C$ is the complexant, the formation constant is defined by Dean as:

$$
K \equiv \frac{[R C]}{[R][C]}
$$

where the [ ]s indicate concentrations. The fraction of $R$ complexed is written as:

$$
\text { Fraction }=\frac{[R C]}{[R]+[R C]}
$$


Now use $[R C]=K[R][C]$ and substitute in the above to obtain:

$$
\text { Fraction }=\frac{K[R][C]}{[R]+K[R][C]}=\frac{K[C]}{1+K[C]}
$$

This is equivalent to:

$$
\text { Fraction }=1-\frac{1}{1+K[C]}=\frac{1+K[C]-1}{1+K[C]}=\frac{K[C]}{1+K[C]}
$$

The calculation result for Am(III) is shown in Table 6.5-2. It can be seen that even at such a high ligand concentration, the complexed americium is less than 2 percent of the total americium in the solution and is therefore negligible compared to free americium ions.

Table 6.5-2. Complexation of $\mathrm{Am}^{3+}$ with Intermediate Metabolites

\begin{tabular}{|l|c|c|c|}
\hline \multicolumn{1}{|c|}{ Organic acid } & Metal & Log K & Am Complexed \\
\hline Formic & $\mathrm{Am}$ & 1.2 & $0.08 \%$ \\
\hline Acetic & $\mathrm{Am}$ & 1.99 & $0.49 \%$ \\
\hline Lactic & $\mathrm{Am}$ & 2.43 & $1.33 \%$ \\
\hline
\end{tabular}

Source: NIST 2003 [DIRS 171201].

NOTE: Percentages of americium complexed are calculated by assuming the concentrations of intermediate metabolites to be $50 \mu \mathrm{M}$.

As mentioned above, another group of organic acids are microbial exudates, among which siderophores are of particular concern. Microbes require iron for DNA synthesis, electron transfer proteins, and nitrogen fixation. However, iron suffers from extreme insolubility in aerobic environments at physiological $\mathrm{pH}$. Aerobic and facultatively anaerobic microorganisms have developed a system to acquire Fe(III). This is accomplished by siderophore generation. Siderophores are low molecular mass, ferric-specific ligands that are induced at low iron concentration for the purpose of biological assimilation of $\mathrm{Fe}(\mathrm{III})$. The most common siderophores contain the hydroxamic acid functional group -R-CO-N(OH)-R', which forms a five-membered chelate ring with $\mathrm{Fe}^{3+}$ (Hersman 1997 [DIRS 100763]). Because $\mathrm{Fe}(\mathrm{III})$ and $\mathrm{Pu}(\mathrm{IV})$ are similar in their charge/ionic radius ratio, $\mathrm{Pu}(\mathrm{IV})$ might serve as an analogue to $\mathrm{Fe}(\mathrm{III})$ (Hersman et al. 1993 [DIRS 100762]). However, in the repository, a large quantity of Fe(III) will be accumulated from oxic steel corrosion (Table 4.1-1), which will overwhelm $\mathrm{Pu}(\mathrm{IV})$ in complexation with siderophores. In addition, under oxidizing conditions anticipated in the repository, plutonium will be dominated by $\mathrm{Pu}(\mathrm{V})$ and $\mathrm{Pu}(\mathrm{VI})$, instead of $\mathrm{Pu}(\mathrm{IV})$ (Table 4.1-1). Therefore, the effect of siderophores for plutonium dissolution will be insignificant.

\subsubsection{Biotransformation and Biosorption of Radionuclides}

Microorganisms are known to accumulate radionuclides both extracellularly and intracellularly. In this section, possible processes of biotransformation and bioaccumulation of radionuclides by microorganisms are summarized based on open literature search. The relevance of these processes to the repository is then evaluated in the context of anticipated repository conditions. 
Studies on the association of uranium with bacteria by nuclear magnetic resonance spectroscopy, by time-resolved laser fluorescence spectroscopy, and by extended X-ray absorption fine structure (EXAFS) analysis have shown the involvement of phosphate and carboxylate groups in uranium binding (Andres et al. 1994 [DIRS 171126]; Henning et al. 2001 [DIRS 171121]; Kelly et al. 2002 [DIRS 171135]).

Francis et al. (2004 [DIRS 171467]) determined the association of uranium with bacteria isolated from WIPP (Carlsbad, New Mexico), and compared this association with known strains of halophilic and nonhalophilic bacteria and archaea. Examination of the cultures by transmission electron microscopy and energy dispersive X-ray spectroscopy showed uranium accumulation extracellularly and/or intracellularly to varying degrees.

In Pseudomonas fluorescens and Bacillus subtilis, uranium was associated at the cell surface, and in the latter it was present as irregularly shaped mineral grains. In Halobacterium halobium, an archaea, uranium was present as dense deposits; in Haloanaerobium praevalens, uranium was present as spikey deposits. Halomonas $s p$. isolated from the WIPP site accumulated uranium both extracellularly (on the cell surface) and intracellularly (as electron-dense discrete granules). EXAFS analysis of uranium with the halophilic and nonhalophilic bacteria and archaea at physiological $\mathrm{pH}$ (5 to 6.8) showed that the uranium present in whole cells was bonded to an average of $2.4 \pm 0.7$ U-P phosphoryl groups at a distance of $3.65 \pm 0.03 \AA$. However, analysis of the cell wall fragments of lysed Halomonas $s p$. showed that uranium formed a bidentate complex with a carboxylate group on the cell wall at $2.91 \pm 0.03 \AA$, and a U-U interaction at $3.71 \pm 0.03$ $\AA$, indicating a precipitated hydroxide phase was also present; no U-P interaction was observed. Addition of uranium to the cell lysate of Halomonas sp. resulted in the precipitation of uranium due to the inorganic phosphate released from the cells. These results show that the microbial polyphosphates and phosphates released from mineralization bind a significant amount of uranium. However, the microbially immobilized uranium mineral phase was readily solubilized by bicarbonate with concurrent release of phosphate into solution.

Spectroscopic techniques have been used to elucidate the functional groups involved in the bonding of uranium with microbial cells. In general, the microbial cell surfaces contain carboxyl, phosphoryl, amino, and hydroxyl functional groups, which are known to form complexes with uranium (Fowle et al. 2000 [DIRS 155808]). ${ }^{31} \mathrm{P}-\mathrm{NMR}$ studies showed that uranium was bound to the phosphate groups of the phospholipid fraction isolated from Mycobacterium smegmatis, and that the phosphate groups and carboxylate groups of the peptidoglycan (Pg) also are involved in its binding (Andres et al. 1994 [DIRS 171126]). Time-resolved laser fluorescence spectroscopy studies of Thiobacillus ferrooxidans and Thiomonas cuprina and several Bacillus species (Bacillus cereus, B. sphaericus, and $B$. megaterium) formed inner-sphere complexes of uranium with organophosphate groups on the cell surface, and that the polysaccharides and teichoic acids of cell walls or the phospholipid layers of membranes were responsible for uranium binding (Panak et al. 1999 [DIRS 171085]).

EXAFS analysis of uranium complexes with B. cereus, B. sphaericus, and B. megaterium have shown that uranium U(VI) is bound to phosphate group (Henning et al. 2001 [DIRS 171121]; Panak et al. 1999 [DIRS 171085]), whereas studies with B. subtilis (Kelly et al. 2002 [DIRS 171135]) show that, at extremely low $\mathrm{pH}(\mathrm{pH} \mathrm{1.67),} \mathrm{U(VI)} \mathrm{binds} \mathrm{exclusively} \mathrm{to}$ phosphoryl functional groups on the cell wall and, with increasing $\mathrm{pH}$ (3.22 and 4.80), U(VI) 
binds increasingly to microbial surface carboxyl functional groups. In a related study, Panak et al. (2002 [DIRS 171120]) showed that, in B. sphaericus, $\mathrm{Pu}(\mathrm{VI})$ was primarily bound to phosphate groups on the cell surface, and no carboxylate complexation was detected. However, the bond lengths between $\mathrm{Pu}(\mathrm{VI})$ and the equatorial oxygens, as well as the phosphorus atoms, are longer in the microbial phosphate complex than in the $\mathrm{Pu}(\mathrm{VI})$ dihydrogen phosphate precipitate with an overall decrease in the number of phosphorus atoms. This led them to conclude that $\mathrm{Pu}(\mathrm{VI})$ is bound to organophosphate groups at the cell surface (Panak et al. 2002 [DIRS 171120]); in addition, EXAFS analysis of several examined microbial species showed the formation to be an inner-sphere complex of uranium with phosphoryl and the carboxyl groups of the microbial cells.

The EXAFS analysis of the whole cells of halophiles, nonhalophiles, and archaea indicates the complexation of uranium predominantly with cellular inorganic phosphate. Although it is difficult to distinguish monophosphate bonding from polyphosphate bonding by EXAFS, the detection of four phosphate bonds to uranium is a good indication of polyphosphate formation. In Halomonas sp., uranium was bound as a diphosphate group with the whole cells, whereas, with the cell walls, it was bound to the carboxylate group as bidentate complex with indications that uranyl hydroxide is present. The complexation of uranium as bidentate complex at physiological $\mathrm{pH}$ has been reported (Fein et al. 1997 [DIRS 100744]).

Polyphosphates are widely distributed throughout the microbial cell. Numerous and varied biological functions are performed by polyphosphate including: phosphate storage in the cell; a reservoir of energy for cellular functions; a chelator of metals (e.g., $\mathrm{Mn}^{2+}$ and $\mathrm{Ca}^{2+}$ ); a pH buffer; a capsule for bacteria; and in physiological adjustments to growth, development, stress, and deprivation (Kornberg 1995 [DIRS 171079]). The amount of polyphosphate that is stored by cells varies between microbial species, and is determined, in part, by the rate at which it can be degraded (for example, in response to the presence of metals), and the amount of inorganic phosphate secreted into the medium. Inasmuch as all of the uranium exposure studies reported were conducted with cells in the stationary phase, the cells are responding to heavy metal stress by releasing phosphate from the mineralization of cellular polyphosphate. In some experiments reported in the literature, the cells were in fact incubated with uranium, from several hours to days. Under these conditions, the cells undergo lysis and release inorganic phosphate $\left(\mathrm{H}_{2} \mathrm{PO}_{4}{ }^{-}\right)$ with the precipitation of uranium as uranyl phosphate $\left[\mathrm{UO}_{2}\left(\mathrm{H}_{2} \mathrm{PO}_{4}\right)_{2}\right]$. These results show that an increase in the concentration of inorganic phosphate released from mineralization of cellular phosphates during starvation or under stress binds significant amounts of uranium.

The possible biotransformation of actinide, and its relevance to the repository, are summarized in Table 6.5-3. Because an oxidizing environment will be maintained in the repository, and because the supply of organic carbon will be limited, reduction of actinides from higher to lower valence states will be unlikely. Even if it occurs, it can be conservatively ignored because it would lead to a lower solubility. For the same reason, microbial activity will not reductively dissolve $\mathrm{Fe}$ (III) oxides generated from oxic metal corrosion and therefore will not change the availability of sorption sites for radionuclides in the repository. Other biotransformation processes may occur, but their impacts on radionuclide mobility will be insignificant (Table 6.5-3). 
Table 6.5-3. Summary of Biotransformation of Actinides and Its Relevance to the YMP

\begin{tabular}{|c|c|c|c|c|c|l|}
\hline Process & Th & $\mathbf{U}$ & Np & Pu & Am & \multicolumn{1}{|c|}{ Relevance to YMP } \\
\hline Biosorption & $?$ & ++++ & + & ++ & + & $\begin{array}{l}\text { Possible, but limited by low microbial activity. It } \\
\text { can be conservatively ignored, because most } \\
\text { microbial cells are associated with solid matrix. }\end{array}$ \\
\hline Reduction $^{\mathrm{a}}$ & - & ++++ & $?$ & $?$ & - & $\begin{array}{l}\text { Minimal due to oxidizing environment. It can be } \\
\text { conservatively ignored, because it leads to a low } \\
\text { solubility. }\end{array}$ \\
\hline Dissolution $^{\mathrm{b}}$ & + & ++ & $?$ & + & $?$ & $\begin{array}{l}\text { Microbially mediated oxidation. Limited by low } \\
\text { microbial activity. No impact on repository } \\
\text { performance, since the solubility model assumes } \\
\text { high oxidation states for all radionuclides (BSC } \\
\text { 2004 [DIRS 169425]). }\end{array}$ \\
\hline Biocolloid $^{\mathrm{c}}$ & + & + & + & + & + & $\begin{array}{l}\text { Possible, but limited by low microbial activity and } \\
\text { mobility. Negligible compared to groundwater } \\
\text { colloids. }\end{array}$ \\
\hline
\end{tabular}

${ }^{a}$ Precipitation due to reduction from higher to lower valence states.

b Due to metabolic products including siderophores; oxidation from lower to higher valence states.

${ }^{c}$ Association of radionuclides with suspended microbial cells.

Legend:

$$
\begin{array}{ll}
? & =\text { Not known. } \\
+ & =\text { Not possible } \\
+ & =\text { Possible. } \\
++ & =\text { Likely. } \\
++++ & =\text { Very likely. }
\end{array}
$$

\subsubsection{Colloid-Facilitated Transport}

Groundwater is expected to be the principal medium for the potential movement of radionuclides from a repository. Colloidal transport of radionuclides is recognized as a potential mechanism of migration, and includes mineral fragments, humic substances, intrinsic colloids, and microorganisms. Microbes fall at the upper end of, and above, the colloidal size range of $1 \mathrm{~nm}$ to $1 \mu \mathrm{m}$. Growing bacteria are several micrometers long, with volumes of several cubic microns; nongrowing bacteria under oligotrophic conditions may be as small as $0.2 \mu \mathrm{m}$ to $0.3 \mu \mathrm{m}$. Significant numbers of bacteria exist in subterranean environments including extreme environments, such as deep-sea hydrothermal vents, hot springs, and deep aquifers; they are present in the groundwaters of all repository environments investigated. Therefore, there has been a concern with a potential radionuclide transport facilitated by suspended microbial cells, often referred to as biocolloids. However, such a mechanism has not been confirmed by experimental data. To the contrary, these data have shown that biocolloids can only travel over a short distance in a porous medium lacking fractures (such as the invert materials in the repository), and the presence of microbial cells and their by-products may even help immobilization of radionuclides.

Francis et al. (1998 [DIRS 171078]) evaluated the interactions of dissolved ${ }^{239} \mathrm{Pu}$ (as plutonium-nitrate, perchlorate and EDTA complex) under anaerobic conditions with a pure culture and a mixed culture of halophilic bacteria isolated from the WIPP repository environments to evaluate the potential transport as biocolloids from the waste site. 
The sizes of the microbial cells ranged from $0.54 \times 0.48 \mu \mathrm{m}$ to $7.7 \times 0.67 \mu \mathrm{m}$. The association of plutonium with suspended microbial cells $\left(10^{6}\right.$ to $10^{9}$ cells $\left./ \mathrm{mL}\right)$ at various growth phases in a medium containing $\mathrm{NaCl}$ or $\mathrm{MgCl}_{2}$ brine was determined by sequential microfiltration. The amount of plutonium associated with the suspended cell fraction (calculated as mol/cell) is low $\left(\mathrm{Pu} 10^{-18}\right.$ to $\mathrm{Pu} 10^{-21}$ ), and it varies with the particular microbial culture. In addition, most cells tend to attach to solid surfaces (Johnson et al. 1974 [DIRS 171153]). These results support other studies that assessed the influence of bacteria on the migration of radionuclides from a deep spent-fuel repository, based on total number of bacteria present; these studies concluded that negligible amounts of the released radionuclides would be bound to unattached bacteria (Pedersen 1996 [DIRS 171086]).

In the presence of microorganisms, colloidal movement through a rock matrix could be reduced because of an overall increase in the size of colloidal particle agglomerates (Hersman 1995 [DIRS 100750]). There are several general interactions between microorganisms and solid surfaces (including colloidal particles) and the effects of microbial adhesion on colloids. These interactions include attraction processes such as adhesion, adsorption, and flocculation. Solid surfaces are potential sites for concentrating nutrients and for the promotion of microbial activity. In addition to movement of water across a solid surface, there are many physico-chemical and biological attraction mechanisms at solid surfaces. These attraction mechanisms include chemotaxis, Brownian motion, electrostatic attraction, van der Waals interaction, electrical double layer effects, and cell surface hydrophobicity (for a more detailed discussion of these processes, refer to Hersman 1995 [DIRS 100750], p. 2-4). Depending on the nature of the particulate matter, fabric organization, clay type, etc., the availability of the substrate may be either enhanced or reduced by the presence of particulates.

If substrates were concentrated on the surface of clay minerals, this would enhance the colonization of microbes on those surfaces. These interactions can lead to the formation of multiple microbial-colloidal particle agglomerates (Hersman 1997 [DIRS 100763]). In addition, Hersman (1995 [DIRS 100750]) indicates that clay colloids can be adsorbed onto the surfaces of microbes. Hersman (1995 [DIRS 100750]; 1997 [DIRS 100763]) discusses the processes that have been patented for the flocculation of clays. They include microbial polysaccharides and nucleoproteins. These processes have the potential to inhibit colloidal transport by increasing particle size.

Adhesion of microorganisms is involved in fouling of man-made surfaces, in microbial influenced corrosion, and in syntrophic and other community interactions between microorganisms in natural habitats. Unlike inorganic colloidal particles, bacteria appear to adhere to surfaces by means of surface polymers, including cellular lipopolysaccharides, extracellular polymers and capsules, pili, fimbriae, and flagella. The composition and quantity of microbial surface polymers vary considerably, and are influenced by growth and environmental conditions (Hersman 1997 [DIRS 100763]). Because of their large sizes, and because of this adhesion effect, microorganisms are expected to be much less liable to be transported in a subsurface system than inorganic colloid particles.

Jewett et al. (1999 [DIRS 154325]) used porous medium column experiments to investigate Pseudomonas fluorescens strain P17 transport as a function of water content and the influences of the solid-liquid and gas-liquid interfaces. The experiments were conducted for sub-rounded 
quartz sand at the water-saturation degrees of 100,84 , and 46 percent. The mean grain diameter of the sand was $158 \mu \mathrm{m}$, with a range of $50 \mu \mathrm{m}$ to $250 \mu \mathrm{m}$. The sand was washed with $\mathrm{HCl} / \mathrm{heat}$ treatment to remove oxide and organic coating from the particle surface. The porosity of the compacted sand was 0.36. Bacteria used in the experiment had a cell size of $0.86 \mu \mathrm{m}$ to $0.90 \mu \mathrm{m}$, and the bacteria were injected into the top of the sand column at a flow velocity of $0.48 \mathrm{~cm} / \mathrm{s}$ to $4.78 \mathrm{~cm} / \mathrm{s}$, and at a concentration of 1.0 cells $/ \mathrm{mL}$ to $1.66 \times 10^{6}$ cells $/ \mathrm{mL}$. The column length is $12.5 \mathrm{~cm}$. The experimental results showed that maximum cell retention occurred in the top centimeter of porous media at all three water contents, and decreased with depth in the column. The total fraction of cells retained was inversely proportional to water content, with nearly twice the cell retention at 46-percent saturation than at 100-percent saturation. 50 percent of cells were retained within the column under the fully saturated condition; 95 percent of the cells were retained at a 46-percent water saturation.

Cattaneo et al. (1997 [DIRS 171059]) studied the transport of Burkholdera cepacia in the unsaturated soil column. The soil used in the experiments was collected from the upper 6 inches of a forest soil. It was sieved $(2 \mathrm{~mm})$ without air drying, and the content and density of the organic matter were measured as 15.5 percent and $2.39 \mathrm{~g} / \mathrm{mL}$. The number of cells was reduced by 90 percent over a 2 -cm percolation distance.

Microbial transport testing was also conducted in a sandy aquifer on the coastal plain of Virginia (DeFlaun et al. 1997 [DIRS 171060]). The 30-m-long flow cell consisted of groundwater production and injection wells, a tracer injection well, and 10 multilevel samplers screened every half meter from $4.0 \mathrm{~m}$ to $10.5 \mathrm{~m}$ below ground surface. The bacteria used in this test were selected for low adhesion to site sediments, so that they might be readily transported through the aquifer. The selected bacteria were then labeled by ${ }^{13} \mathrm{C}$ for detection. The results from this field test indicate that bacteria traveled the length of the flow field $(4 \mathrm{~m})$, but the majority of the injected biomass was retained in the sediments between the injection well and the first multilevel sampler at $0.5 \mathrm{~m}$.

Furthermore, field measurements indicate that most microbial cells are associated with solid matrix. For example, in the Rocky Flats Plant Pond B-1, the cell density in the sediments ranges from 3 to $300 \times 10^{6}$ cells $/ \mathrm{mL}$ for aerobes and from 0.2 to $2 \times 10^{6}$ cells $/ \mathrm{mL}$ for anaerobes; the waters have only 1.1 to $340 \times 10^{3} / \mathrm{mL}$ for aerobes and 2 to $7.8 \times 10^{2} / \mathrm{mL}$ for anaerobes (Johnson et al. 1974 [DIRS 171153]). In this case, less than 1 percent of cells are in suspension. Therefore, if biosorption and bioaccumulation occur, microbes tend to immobilize radionuclides in subsurface systems.

Based on the above discussion, given that the invert material is composed of crushed tuff rocks, which can be considered a nonfractured porous medium, biocolloids generated in the Yucca Mountain drift will be, at least partly, filtered out within the invert. 
The transport of microbes through fractures must exist. Otherwise, there are no microbes that can be detected in the rock, because volcanic ash precluded inclusion of microbes de novo. However, transport and the facilitated radionuclide migration are expected to be limited due to:

- Low liquid-water saturation (Section 6.4.3)

- High-ionic strength, which tends to destabilize colloidal suspension (BSC 2004 [DIRS 170025], Section 6.3.2)

- Low microbial activity, as discussed in Section 6.4.

Even if microbial cells can transport through rock fractures in unsaturated and saturated zones, their impact on radionuclide transport is still negligible. The concentration of microbial cells in the in-drift water $\left(<7 \times 10^{7}\right.$ cells $/ \mathrm{mL}$, see Section 6.5) is much lower than the concentration of groundwater colloids $\left(10^{6}-10^{11}\right.$ particles/mL) (BSC 2004 [DIRS 170025], Figure 6-11).

\subsection{UNCERTAINTIES}

The evaluation of the impacts of microbial activity on the Yucca Mountain in-drift chemistry, as summarized above, is based on bounding analyses. Therefore, uncertainties associated with input parameters used in this report are fully captured. Variations in the input parameter values within reasonably expected ranges will not change the conclusions drawn in this report. 


\section{CONCLUSIONS}

\subsection{EVALUATION CONCLUSIONS}

This evaluation addresses eight FEPs, as listed in Tables 6.2-1 and 6.2-2. Table 6.2-1 identifies the section(s) in this report that develop information for inclusion of a FEP in the TSPA-LA. Table 6.2-2 identifies the section(s) that develop information for exclusion of a FEP from the TSPA-LA.

Based on different nutritional requirements, microorganisms are categorized into one of two groups:

- Heterotrophs, which use organic carbon compounds as their carbon and energy source

- Autotrophs, which derive their energy from the oxidation of inorganic compounds and derive cell carbon from $\mathrm{CO}_{2}$.

Section 6.1 of this report describes the systematics of repository biochemistry. In the repository, heterotrophic microbial activity is limited by the lack of a significant organic carbon supply; autotrophic microbial activity is limited by the lack of available inorganic electron donors in an oxic environment. Microbial analyses conducted in the ESF have determined the existence of aerobic heterotrophs and autotrophs. The organisms present include iron oxidizing, sulfur oxidizing and nitrifying organisms. Cell counts range from 10 to 500 cells per gram of tuff for autotrophs, and from $3.2 \times 10^{4}$ to $2 \times 10^{5}$ cells per gram for heterotrophs. The total microbial population at Yucca Mountain is relatively low in comparison to other subsurface environments. The direct DNA extraction and 16S rDNA analysis have demonstrated that microorganisms at the Yucca Mountain site are highly adaptive and sufficiently diverse to carry out any specific metabolic reaction that the environment permits.

The following environmental factors severely limit microbial activity in the repository:

- The in-drift temperatures during the thermal pulse will exceed the temperature tolerance of all known microbes for a significant portion of the repository time, thus exerting a sterilization effect on microorganisms.

- An oxic environment will prevail in the repository over the growth-permissive period and therefore prevent the generation and accumulation of reduced inorganic species that are the prerequisite for autotrophic metabolism.

- Microbial incubation experiments have demonstrated that water availability is the primary limiting factor for Yucca Mountain microbial growth. The relative humidity and the liquid-water saturation in the repository are predicted to be low for a significant duration, thus further limiting microbial activity.

- Evaporation of seepage waters in the low relative humidity environment due to radiation heat will result in brine solutions with ionic strengths higher than $10 \mathrm{M}$, which is an environment in which only a few halophiles may be able to survive. The activity of 
these microbes should be limited after the thermal pulse, when low ionic strength environments are reestablished.

- Organic carbon is an important limiting factor for Yucca Mountain microbial growth. The extremely low organic carbon supply in the repository will limit heterotrophic microbial activity.

- Elevated temperatures, radiation fields, low humidity, and low nutrient supplies, will severely limit the formation of biofilm in the repository.

Due to the aforementioned environmental constraints, the microbial activity in the repository is expected to be low, and its impacts on drift chemistry can be negligible:

- Yucca Mountain groundwater only contains a trace concentration of organic carbon, which is negligible compared to the total carbonate concentration in the solution. Furthermore, an autotrophic microbial reaction, if it occurs, will not generate $\mathrm{CO}_{2}$, because it is a $\mathrm{CO}_{2}$-fixation process, and the accumulated biomass will probably be recycled back to $\mathrm{CO}_{2}$, resulting in zero $\mathrm{CO}_{2}$ accumulation or depletion. Even if all the organic carbon were converted to carbon dioxide, the perturbation to the water chemistry is negligible. Therefore, the impact of microbial activity on water chemistry $(\mathrm{pH}$ and $\Sigma \mathrm{CO}_{2}$ ) will be negligible.

- In an oligotrophic environment such as the repository, microbial activity is limited, and the concentrations of the microbially generated low-MW organic acids are expected to be very low $(<50 \mu \mathrm{M})$. Bounding calculations show that the complexation effect of these organic acids on radionuclide dissolution is negligible.

- Because an oxic environment will prevail in the repository, actinide precipitation due to reduction from higher to lower valence states will be limited and can be ignored. For the same reason, microbial activity will not reductively dissolve Fe(III) oxides generated from oxic metal corrosion and therefore will not change the availability of sorption sites for radionuclides in the repository. Other biotransformation processes (such as dissolution due to oxidation reactions, production of sequestering agents, and biosorption) may occur, but their impacts on radionuclide mobility will be insignificant.

- Because of the oxic environment, denitrification is inhibited. Significant microbial consumption of nitrate will not occur.

- The concentration of suspended microbial cells is low compared to that of groundwater colloid particles, and a separated consideration of biocolloid-facilitated transport is not necessary in the Yucca Mountain environment. Field measurements indicate that a majority of microbial cells are attached to solid matrix. Through biosorption and bioaccumulation, microbes actually tend to immobilize radionuclides in subsurface systems.

MIC could be a potential concern for the integrity of the waste package. Although this report is not intended to address MIC specifically, it does provide boundary conditions for evaluating the 
potential effect of microbial activity on waste package corrosion in relevant Yucca Mountain environments. As summarized in this section, microbial activity in the Yucca Mountain repository is expected to be minimal due to the environmental limitations. Specifically, the following factors will limit, if not completely prevent, microbially influenced corrosion:

- Oxic environments will prevail in the repository over the regulatory time period. Therefore, sulfate reduction (an anaerobic reaction pathway generally considered to be responsible for MIC) is unlikely to occur. Microbial oxidation of sulfide will be unlikely, due to a lack of reduced sulfur species in the repository.

- The repository transient conditions of decreased relative humidity, elevated temperature, and high radiation doses, together with limited nutrient supplies, will prevent the formation of biofilms, which are required for MIC.

As discussed in Section 6.4.3, although microbes can be active at a relative humidity as low as 75 percent, most microbes can thrive only when relative humidity is above 90 percent. For the purpose of TSPA calculations, it is recommended to choose 90 percent relative humidity as a threshold for MIC. This choice likely leads to an overestimate of the MIC effect, because other factors (such as elevated temperature, high radiation dose, and limited nutrient supplies) will also limit microbial activity; microbes will require even higher relative humidity to maintain their active metabolism. Microbial activity, including MIC, is expected to be minimal in the Yucca Mountain repository.

The qualitative analyses and bounding calculations in this evaluation fully capture the ranges of uncertainty in the inputs. Therefore, the potential impact of microbial activity on drift chemistry does not warrant a direct feed to the TSPA-LA. That is, the above conclusions support arguments in Engineered Barrier System Features, Events, and Processes (BSC 2004 [DIRS 169898]) and therefore each FEP addressed in this report will either:

- Exclude the FEP from the TSPA-LA on the basis of low consequence, or

- Have a TSPA-LA disposition of the FEP in which the contribution from microbial activity can be neglected.

\subsection{YUCCA MOUNTAIN REVIEW PLAN CRITERIA ASSESSMENT}

This model predicts results that directly pertain to the abstraction of the quantity and chemistry of water contacting engineered barriers and waste forms. This section summarizes the contents of this report as they apply to NRC criteria for a detailed review of that abstraction. These are the relevant criteria from Yucca Mountain Review Plan, Final Report (NRC 2003 [DIRS 163274], Section 2.2.1.3.3.3), which is from 10 CFR 63.114(a) - (c) and (e) - (g) [DIRS 156605].

- Acceptance Criterion 1 - System Description and Model Integration Are Adequate.

(1) Total system performance assessment adequately incorporates important design features, physical phenomena, and couplings, and uses consistent and appropriate 
assumptions throughout the quantity and chemistry of water contacting engineered barriers and waste forms abstraction process.

This evaluation incorporates current design features and latest analyses of physical phenomena and couplings by taking inputs directly from current IEDs and current analyses and model reports, as listed in Table 4.1-1. The use of these sources also ensures that appropriate assumptions have been consistently used throughout the abstraction process.

(2) The abstraction of the quantity and chemistry of water contacting engineered barriers and waste forms uses assumptions, technical bases, data, and models, that are appropriate and consistent with other related U.S. Department of Energy abstractions. For example, the assumptions used for the quantity and chemistry of water contacting engineered barriers and waste forms are consistent with the abstractions of "Degradation of Engineered Barriers" (Section 2.2.1.3.1); "Mechanical Disruption of Engineered Barriers (Section 2.2.1.3.2); "Radionuclide Release Rates and Solubility Limits" (Section 2.2.1.3.4); "Climate and Infiltration" (Section 2.2.1.3.5); and "Flow Paths in the Unsaturated Zone" (Section 2.2.1.3.6). The descriptions and technical bases provide transparent and traceable support for the abstraction of quantity and chemistry of water contacting engineered barriers and waste forms.

The assumptions and models used in this evaluation are the same as those incorporated in the analyses that establish the technical bases for this evaluation and the technical bases for related abstractions. Other data (Table 4.1-2) are widely accepted constraints on microbial activity that are justified in Table 4.1-3. These data are appropriate and consistent with other related abstractions.

(3) Important design features, such as waste package design and material selection, backfill, drip shield, ground support, thermal loading strategy, and degradation processes, are adequate to determine the initial and boundary conditions for calculations of the quantity and chemistry of water contacting engineered barriers and waste forms.

The sources for the boundary conditions for this evaluation, which are listed in Table 4.1-1, address that the important design features are adequate to determine those boundary conditions.

(4) Spatial and temporal abstractions appropriately address physical couplings (thermal-hydrologic-mechanical-chemical). For example, the U.S. Department of Energy evaluates the potential for focusing of water flow into drifts, caused by coupled thermal-hydrologic-mechanical-chemical processes.

This evaluation appropriately addresses physical couplings by taking its boundary conditions from sources (Table 4.1-1) that appropriately have addressed those couplings.

(5) Sufficient technical bases and justification are provided for total system performance assessment assumptions and approximations for modeling coupled thermal-hydrologic-mechanical-chemical effects on seepage and flow, the waste package chemical environment, and the chemical environment for radionuclide 
release. The effects of distribution of flow on the amount of water contacting the engineered barriers and waste forms are consistently addressed, in all relevant abstractions.

Technical bases and justification for modeling coupled effects on seepage and flow are addressed in the sources (Table 4.1-1) for the boundary conditions used in this evaluation. These sources also address the technical bases and justification for modeling the chemical environments in the absence of microbial activity. This evaluation does not make use of any additional assumptions or approximations.

(6) The expected ranges of environmental conditions within the waste package emplacement drifts, inside of breached waste packages, and contacting the waste forms and their evolution with time are identified. These ranges may be developed to include:

(i) the effects of the drip shield and backfill on the quantity and chemistry of water (e.g., the potential for condensate formation and dripping from the underside of the shield);

(ii) conditions that promote corrosion of engineered barriers and degradation of waste forms;

(iii) irregular wet and dry cycles;

(iv) gamma-radiolysis; and

(v) size and distribution of penetrations of engineered barriers.

This evaluation is based on qualitative analyses and bounding arguments that capture the entire expected ranges of environmental conditions as they evolve over time. Figure 6.4-5 provides an example of an input that includes the expected ranges.

(7) The model abstraction for quantity and chemistry of water contacting engineered barriers and waste forms is consistent with the detailed information on engineered barrier design and other engineered features. For example, consistency is demonstrated for:

(i) dimensionality of the abstractions;

(ii) various design features and site characteristics; and

(iii) alternative conceptual approaches.

Analyses are adequate to demonstrate that no deleterious effects are caused by design or site features that the U.S. Department of Energy does not take into account in this abstraction. 
Detailed information on EBS design provides the basis for the analyses that provide boundary conditions for the evaluation. Multiscale Thermohydrological Model (BSC 2004 [DIRS 169565]) includes an especially detailed model of the EBS, and provides input to this evaluation. Therefore, this evaluation is consistent with the detailed design information.

(8) Adequate technical bases are provided, including activities such as independent modeling, laboratory or field data, or sensitivity studies, for inclusion of any thermal-hydrologic-mechanical-chemical couplings and features, events, and processes; and

The sources of boundary conditions for this evaluation (Table 4.1-1) address that the technical basis for inclusion of thermal-hydrologic-mechanical-chemical couplings is adequate. Section 6.2 lists the FEPs addressed by this evaluation, and the location where each FEP is addressed. These sections provide the technical bases for exclusion or disposition of these FEPs in the TSPA-LA.

(9) Performance-affecting processes that have been observed in thermal-hydrologic tests and experiments are included into the performance assessment. For example, the U.S. Department of Energy either demonstrates that liquid water will not reflux into the underground facility or incorporates refluxing water into the performance assessment calculation, and bounds the potential adverse effects of alteration of the hydraulic pathway that result from refluxing water.

This sub-criterion is not applicable to the evaluation of microbial impacts because observations in thermal-hydrologic tests and experiments have been consistent with thermal-hydrologic predictions that neglected microbial impacts.

(10) Likely modes for container corrosion are identified and considered in determining the quantity and chemistry of water entering the engineered barriers and contacting waste forms. For example, the model abstractions consistently address the role of parameters, such as $\mathrm{pH}$, carbonate concentration, and the effect of corrosion on the quantity and chemistry of water contacting engineered barriers and waste forms.

Section 6.5.1 includes a bounding analysis that demonstrates that the container-corrosion effects on water chemistry do not significantly alter the environmental factors that limit microbial activity. Other effects of container corrosion on the chemistry of water are identified and considered in Engineered Barrier System: Physical and Chemical Environment (BSC 2004 [DIRS 169860]).

(11) The abstraction of in-package criticality or external-to-package criticality, within the emplacement drift, provides an adequate technical basis for screening these events.

This evaluation does not address criticality.

(12) Guidance in NUREG-1297 and NUREG-1298 or other acceptable approaches, is followed. 
Inputs were selected and documented, and documentation was developed, checked, and reviewed in accordance with applicable BSC and Office of Civilian Radioactive Waste Management procedures, which comply with NUREG-1297 [DIRS 103597] and NUREG-1298 [DIRS 103750] (see Section 2).

- Acceptance Criterion 2 - Data Are Sufficient for Model Justification.

(1) Geological, hydrological, and geochemical values used in the license application are adequately justified. Adequate description of how the data were used, interpreted, and appropriately synthesized into the parameters is provided.

This evaluation uses geological, hydrologic, or geochemical values indirectly from the sources that provided environmental boundary conditions, which are adequately justified (Table 4.1-1). The development of the parameters from the data is addressed in the referenced sources.

(2) Sufficient data were collected on the characteristics of the natural system and engineered materials to establish initial and boundary conditions for conceptual models of thermal-hydrologic-mechanical-chemical coupled processes, that affect seepage and flow and the engineered barrier chemical environment.

This evaluation uses boundary values from data collected on the abundance of organic carbon and orthophosphate in groundwater near the repository site (Table 4.1-1). This evaluation uses other data on the characteristics of the natural system, indirectly from the sources that provided environmental boundary conditions (Table 4.1-1). The information on engineered materials required to conclude that microbial activity is limited is the recognition that emplacement drift committed materials have no organic components (Table 4.1 1).

(3) Thermo-hydrologic tests were designed and conducted with the explicit objectives of observing thermal-hydrologic processes for the temperature ranges expected for repository conditions and making measurements for mathematical models. Data are sufficient to verify that thermal-hydrologic conceptual models address important thermal-hydrologic phenomena.

This sub-criterion is not applicable to the evaluation of microbial impacts because the relevant thermal-hydrologic tests are addressed in the sources that provide the boundary conditions (Table 4.1-1) for this evaluation.

(4) Sufficient information to formulate the conceptual approach(es) for analyzing water contact with the drip shield, engineered barriers, and waste forms is provided.

This sub-criterion is not applicable to the evaluation of microbial impacts because this evaluation does not address the contact of water with the drip shield, engineered barriers, or waste forms.

(5) Sufficient data are provided to complete a nutrient- and energy-inventory calculation, if it has been used to justify the inclusion of the potential for microbial activity affecting the engineered barrier chemical environment and the chemical environment for radionuclide release. As necessary, data are adequate 
to support determination of the probability for MIC and microbial effects, such as production of organic byproducts and microbially enhanced dissolution of the high-level radioactive waste glass form.

Section 6.4 provides bounding analyses and qualitative assessments of environmental constraints, including nutrient availability. These constraints support the exclusion of the impacts of microbial activity on the engineered barrier chemical environment and on the chemical environment for radionuclide release. Section 6.5.1 includes a boundary analysis demonstrating that corrosion does not significantly affect the bulk chemical environment. Therefore, the impact of microbial activity on the bulk chemical environment does not affect the probability for MIC and microbially enhanced dissolution of the high-level radioactive waste glass form.

- Acceptance Criterion 3 - Data Uncertainty Is Characterized and Propagated Through the Model Abstraction.

(1) Models use parameter values, assumed ranges, probability distributions, and bounding assumptions that are technically defensible, reasonably account for uncertainties and variabilities, and do not result in an under-representation of the risk estimate.

In this evaluation, bounding calculations and qualitative analyses are from sources (Table 4.1-1) that provide ranges of boundary conditions. These ranges include results for the full range of expected inputs, and capture the associated uncertainties (i.e., see Figure 6.4-5). Data from outside sources (Table 4.1-2) are widely accepted by the scientific community, and are justified in Table 4.1-3. Other inputs (Table 4.1-4) are generally accepted qualitative statements. Therefore, models that neglect the impact of microbial activity on drift chemistry reasonably account for uncertainties and variabilities in these impacts and do not result in an under-representation of the risk estimate.

(2) Parameter values, assumed ranges, probability distributions, and bounding assumptions used in the total system performance assessment calculations of quantity and chemistry of water contacting engineered barriers and waste forms are technically defensible and reasonable, based on data from the Yucca Mountain region (e.g., results from large block and drift-scale heater and niche tests), and a combination of techniques that may include laboratory experiments, field measurements, natural analog research, and process-level modeling studies.

This document supports the exclusion of the impacts of microbial activity on drift chemistry from the TSPA-LA. As a result, this evaluation does not provide any parameter values, assumed ranges, probability distributions, or bounding assumptions for use in the TSPA-LA.

(3) Input values used in the total system performance assessment calculations of quantity and chemistry of water contacting engineered barriers (e.g., drip shield and waste package) are consistent with the initial and boundary conditions and the assumptions of the conceptual models and design concepts for the Yucca Mountain site. Correlations between input values are appropriately established in 
the U.S. Department of Energy total system performance assessment. Parameters used to define initial conditions, boundary conditions, and computational domain in sensitivity analyses involving coupled thermal-hydrologic-mechanicalchemical effects on seepage and flow, the waste package chemical environment, and the chemical environment for radionuclide release, are consistent with available data. Reasonable or conservative ranges of parameters or functional relations are established.

This document supports the exclusion of the impact of microbial activity on drift chemistry from the TSPA-LA. Therefore, this evaluation does not provide any input values to the TSPA-LA.

(4) Adequate representation of uncertainties in the characteristics of the natural system and engineered materials is provided in parameter development for conceptual models, process-level models, and alternative conceptual models. The U.S. Department of Energy may constrain these uncertainties using sensitivity analyses or conservative limits. For example, the U.S. Department of Energy demonstrates how parameters used to describe flow through the engineered barrier system bound the effects of backfill and excavation-induced changes.

This sub-criterion is not applicable to the evaluation of microbial impacts on drift chemistry because the evaluation does not make use of conceptual models or process-level models, and therefore no alternative conceptual models.

(5) If criticality is included in the total system performance assessment, the U.S. Department of Energy uses an appropriate range of input parameters for calculating the effective neutron multiplication factor.

This sub-criterion is not applicable because this evaluation does not address criticality.

(6) Where sufficient data do not exist, the definition of parameter values and conceptual models is based on other appropriate sources, such as expert elicitation conducted in accordance with NUREG-1563 [DIRS 100909].

In this evaluation, sufficient data exist for the definition of parameter values. The evaluation does not make use of conceptual models.

- Acceptance Criterion 4 - Model Uncertainty Is Characterized and Propagated Through the Model Abstraction.

This criterion is not applicable to this evaluation of microbial impacts on drift chemistry because the evaluation does not use any models.

- Acceptance Criterion 5 - Model Abstraction Output Is Supported by Objective Comparisons.

This document supports the exclusion of the impacts of microbial activity on drift chemistry from the TSPA-LA. As a result, this evaluation does not provide input to the model abstraction, and this criterion is not applicable. 


\subsection{REQUIRED DOCUMENTATION OF LEVEL OF ACCURACY}

This evaluation is based on bounding calculations and qualitative analyses that capture the full range of expected emplacement drift environments, including uncertainty (Section 6.6). Therefore, the conclusion of insignificant impacts on bulk chemistry (Section 7.1) is representative of expected environments, and level of accuracy and precision are not relevant.

\subsection{COMPLETION CRITERIA}

This evaluation is consistent with the activities performed as part of Technical Work Plan: Regulatory Integration Evaluation of Analysis and Model Reports Supporting the TSPA-LA (BSC 2004 [DIRS 169653]), and fulfills a portion of the Phase 2 work identified in that plan. That is, the work addresses the prioritized list of actions selected in Phase 1 for disposition in Phase 2 (BSC 2004 [DIRS 169653], Section 1.3). 


\section{INPUTS AND REFERENCES}

\subsection{DOCUMENTS CITED}

Altman, W.D.; Donnelly, J.P.; and Kennedy, J.E. 1988. Qualification of Existing

103750

Data for High-Level Nuclear Waste Repositories: Generic Technical Position.

NUREG-1298. Washington, D.C.: U.S. Nuclear Regulatory Commission.

TIC: 200652.

Altman, W.D.; Donnelly, J.P.; and Kennedy, J.E. 1988. Peer Review for High-Level

103597

Nuclear Waste Repositories: Generic Technical Position. NUREG-1297.

Washington, D.C.: U.S. Nuclear Regulatory Commission. TIC: 200651.

Amy, P.S. 1997. "Microbial Dormancy and Survival in the Subsurface." Chapter

100696

11 of The Microbiology of the Terrestrial Deep Subsurface. Amy, P.S. and

Haldeman, D.L., eds. Boca Raton, Florida: CRC Lewis Publishers. TIC: 232570.

Amy, P.S. and Haldeman, D.L. 1997. The Microbiology of the Terrestrial Deep

100697

Subsurface. Boca Raton, Florida: CRC Lewis Publishers. TIC: 232570.

Amy, P.S.; Haldeman, D.L.; Ringelberg, D.; Hall, D.H.; and Russell, C. 1992.

116973

"Comparison of Identification Systems for Classification of Bacteria Isolated from

Water and Endolithic Habitats Within the Deep Subsurface." Applied and

Environmental Microbiology, 58, (10), 3367-3373. Washington, D.C.: American

Society for Microbiology. TIC: 234722.

Andres, Y.; MacCordick, H.J.; and Hubert, J-C. 1994. "Binding Sites of Sorbed

171126

Uranyl Ion in the Cell Wall of Mycobacterium Smegmatis." FEMS Microbiology

Letters, 115, (1), 27-32. New York, New York: Elsevier. TIC: 256368.

Atlas, R.M. and Bartha, R. 1981. Microbial Ecology: Fundamentals and

118890

Applications. Reading, Massachusetts: Addison-Wesley Publishing. TIC: 246870.

Au, F.H.F. and Leavitt, V.D. 1982. "The Soil Microbiota of Area 13 of the Nevada

171090

Test Site." The Radioecology of Transuranics and Other Radionuclides in Desert

Ecosystems. Howard, W.A. and Dunaway, P.B.; eds. NVO-224. 201-242. Las

Vegas, Nevada: U.S. Department of Energy, Nevada Operations Office.

TIC: 201831.

Auerbach, I.D.; Sorensen, C.; Hansma, H.G.; and Holden, P.A. 2000. "Physical

Morphology and Surface Properties of Unsaturated Pseudomonas Putida Biofilms." Journal of Bacteriology, 182, (13), 3809-3815. Washington, D.C.: American

Society for Microbiology. TIC: 256417. 
Baedecker, M.J.; Cozzarelli, I.M.; Eganhouse, R.P.; Siegel, D.I.; and Bennett, P.C. 171125 1993. "Crude Oil in a Shallow Sand and Gravel Aquifer - III. Biogeochemical Reactions and Mass Balance Modeling in Anoxic Groundwater." Applied Geochemistry, 8, 569-583. New York, New York: Pergamon Press. TIC: 256366.

Balkwill, D.L. 1989. "Numbers, Diversity, and Morphological Characteristics of 171091 Aerobic, Chemoheterotrophic Bacteria in Deep Subsurface Sediments from a Site in South Carolina." Geomicrobiology Journal, 7, 33-52. London, England: Taylor \& Francis. TIC: 256428.

Banfield, J.F. and Nealson, K.H., eds. 1997. Geomicrobiology: Interactions 100703 Between Microbes and Minerals. Reviews in Mineralogy Volume 35. Washington, D.C.: Mineralogical Society of America. TIC: 236757.

Barnhart, B.J.; Campbell, E.W.; Martinez, E.; Caldwell, D.E.; and Hallett, R. 1980. Potential Microbial Impact on Transuranic Wastes under Conditions Expected in the Waste Isolation Pilot Plant (WIPP). LA-8297-PR. Los Alamos, New Mexico: Los Alamos Scientific Laboratory. ACC: MOL.20041007.006.

Barnhart,B.J.; Campbell, E.W.; Hardin, J.M.; Martinez, E.; Caldwell, D.E.; and 171092 Hallett, R. 1979. Potential Microbial Impact on Transuranic Wastes Under Conditions Expected in the Waste Isolation Pilot Plant (WIPP). LA-7788-PR. Los Alamos, New Mexico: Los Alamos Scientific Laboratory. TIC: 205965.

Benson, D.A.; Karsch-Mizrachi, I.; Lipman, D.J.; Ostell, J.; Rapp, B.A.; and 171117 Wheeler, D.L. 2000. “GenBank.” Nucleic Acids Research, 28, (1), 15-18. New York, New York: Oxford University Press. TIC: 256370.

Brockman, F.J.; Kieft, T.L.; Fredrickson, J.K.; Bjornstad, B.N.; Li, S-M.W.; 171110 Spangerburg, W.; and Long, P.E. 1992. "Microbiology of Vadose Zone Paleosols in South-Central Washington State." Microbiology Ecology, 23, 279-301. New York, New York: Springer-Verlag. TIC: 256423.

Brown, A.D. 1976. "Microbial Water Stress.” Bacteriological Reviews, 40, (4), 803-846. Baltimore, Maryland: Williams \& Wilkins. TIC: 247695.

BSC (Bechtel SAIC Company) 2004. D\&E/ PA/C IED Subsurface Facilities Committed Materials. 800-IED-WIS0-00301-000-00B. Las Vegas, Nevada: Bechtel SAIC Company. ACC: ENG.20040318.0030.

BSC 2004. Dissolved Concentration Limits of Radioactive Elements. 169425 ANL-WIS-MD-000010 REV 03. Las Vegas, Nevada: Bechtel SAIC Company. ACC: DOC.20041109.0006.

BSC 2004. Drift-Scale THC Seepage Model. MDL-NBS-HS-000001, Rev. 03. Las Vegas, Nevada: Bechtel SAIC Company. ACC: DOC.20041111.0001. 
BSC 2004. EBS Radionuclide Transport Abstraction. ANL-WIS-PA-000001, 169868 Rev. 01. Las Vegas, Nevada: Bechtel SAIC Company.

BSC 2004. Engineered Barrier System: Physical and Chemical Environment. 169860 ANL-EBS-MD-000033, Rev. 03. Las Vegas, Nevada: Bechtel SAIC Company.

BSC 2004. General Corrosion and Localized Corrosion of Waste Package Outer 169984 Barrier. ANL-EBS-MD-000003 REV 02. Las Vegas, Nevada: Bechtel SAIC Company. ACC: DOC.20041004.0001.

BSC 2004. Multiscale Thermohydrologic Model. ANL-EBS-MD-000049 REV 02. Las Vegas, Nevada: Bechtel SAIC Company. ACC: DOC.20041014.0008.

BSC 2004. Postclosure Modeling and Analyses Design Parameters. 169885 TDR-MGR-MD-000037, Rev. 00. Las Vegas, Nevada: Bechtel SAIC Company.

BSC 2004. Q-List. 000-30R-MGR0-00500-000-000 REV 00. Las Vegas, Nevada: Bechtel SAIC Company. ACC: ENG.20040721.0007.

BSC 2004. Technical Work Plan for: Regulatory Integration Evaluation of Analysis and Model Reports Supporting the TSPA-LA. TWP-MGR-PA-000014 REV 00 ICN 01. Las Vegas, Nevada: Bechtel SAIC Company. ACC: DOC.20040603.0001.

BSC 2004. Technical Work Plan for: Near-Field Environment and Transport In-Drift Geochemistry Analyses. TWP-MGR-PA-000013 REV 02. Las Vegas, Nevada: Bechtel SAIC Company. ACC: DOC.20041101.0001.

BSC 2004. Waste Form and In-Drift Colloids-Associated Radionuclide 170025 Concentrations: Abstraction and Summary. MDL-EBS-PA-000004 REV 01. Las Vegas, Nevada: Bechtel SAIC Company. ACC: DOC.20041028.0007.

BSC 2004. Yucca Mountain Site Description. TDR-CRW-GS-000001 REV 02 ICN 169734 01. Two volumes. Las Vegas, Nevada: Bechtel SAIC Company.

ACC: DOC.20040504.0008.

Cattaneo, M.V.; Masson, C.; and Greer, C.W. 1997. "The Influence of Moisture on 171059 Microbial Transport, Survival and 2,4-D Biodegradation with a Genetically Marked Burkholderia Cepacia in Unsaturated Soil Columns." Biodegradation, 8, 87-96. Dordrecht, The Netherlands: Kluwer Academic Publishers. TIC: 256358.

Chapelle, F.H. 2001. Ground-Water Microbiology and Geochemistry. 2nd Edition. New York, New York: John Wiley \& Sons. TIC: 256411.

Colwell, F.S. 1989. "Microbiological Comparison of Surface Soil and Unsaturated Subsurface Soil from a Semiarid High Desert." Applied and Environmental Microbiology, 55, (9), 2420-2423. Washington, D.C.: American Society for Microbiology. TIC: 256436. 
CRWMS (Civilian Radioactive Waste Management System) M\&O (Management and Operating Contractor) 2000. In-Drift Microbial Communities.

ANL-EBS-MD-000038 REV 00 ICN 01. Las Vegas, Nevada: CRWMS M\&O.

ACC: MOL.20001213.0066.

Dean, J.A. 1992. Lange's Handbook of Chemistry. 14th Edition. New York, New

100722

York: McGraw-Hill. TIC: 240690.

DeFlaun, M.F.; Murray, C.J.; Holben, W.; Scheibe, T.; Mills, A.; Ginn, T.; Griffin, T.; Majer, E; and Wilson, J.L. 1997. "Preliminary Observations on Bacterial

Transport in a Coastal Plain Aquifer." FEMS Microbiology Reviews, 20, 473-487.

New York, New York: Elsevier. TIC: 256363.

Delany, J.M. 1985. Reaction of Topopah Spring Tuff with J-13 Water: A

100134

Geochemical Modeling Approach Using the EQ3/6 Reaction Path Code.

UCRL-53631. Livermore, California: Lawrence Livermore National Laboratory.

ACC: HQS.19880517.2419.

DOE (U.S. Department of Energy) 2004. Quality Assurance Requirements and

171539

Description. DOE/RW-0333P, Rev. 16. Washington, D.C.: U.S. Department of Energy, Office of Civilian Radioactive Waste Management.

ACC: DOC.20040907.0002.

Drever, J.I. 1997. The Geochemistry of Natural Waters, Surface and Groundwater

Environments. 3rd Edition. Upper Saddle River, New Jersey: Prentice Hall.

TIC: 246732.

Ehrlich, H.L. 1996. Geomicrobiology. 3rd Edition. New York, New York: Marcel Dekker. TIC: 247746.

Else, T.A.; Pantle, C.R.; and Amy, P.S. 2003. "Boundaries for Biofilm Formation: Humidity and Temperature." Applied and Environmental Microbiology, 69, (8), 5006-5010. Washington, D.C.: American Society for Microbiology. TIC: 255916.

Eriksen, W.H. and Emborg, C. 1978. "Increase of Radiation Resistance of a Soil Microflora Exposed to Long-Term Gamma Irradiation.” Applied Environmental Microbiology, 36, (4), 618-619. Washington, D.C.: American Society for Microbiology. TIC: 256422.

Fein, J.B.; Daughney, C.J.; Yee, N.; and Davis, T.A. 1997. "A Chemical 100744 Equilibrium Model for Metal Adsorption onto Bacterial Surfaces." Geochimica et Cosmochimica Acta, 61, (16), 3319-3328. New York, New York: Pergamon Press. TIC: 238695.

Fowle, D.A.; Fein, J.B.; and Martin, A.M. 2000. "Experimental Study of Uranyl 155808 Adsorption onto Bacillus Subtilis.” Environmental Science \& Technology, 34, (17), 3737-3741. Washington, D.C.: American Chemical Society. TIC: 250659. 
Francis, A.J. 1990. "Microbial Dissolution and Stabilization of Toxic Metals and

Radionuclides in Mixed Wastes." Experientia, 46, 840-851. Basel, Switzerland: Birkhäuser Verlag. TIC: 256398.

Francis, A.J. and Quinby, H.L. 1981. Microbial Degradation of Spent Reactor 171114 Resins-A Preliminary Study. BNL 30897. Uptown, New York: Brookhaven National Laboratory. ACC: MOL.20040901.0201.

Francis, A.J.; Dodge, C.J.; Gillow, J.B.; and Cline, J.E. 1991. "Microbial Transformations of Uranium Wastes." Radiochimica Acta, 52/53, 311-316. München, Germany: Oldenbourg Verlag. TIC: 256433.

Francis, A.J.; Dodge, C.J.; Lu, F.; Halada, G.P.; and Clayton, C.R. 1994. "XPS and 110014 XANES Studies of Uranium Reduction by Clostridium sp." Environmental Science \& Technology, 28, 636-639. Easton, Pennsylvania: American Chemical Society. TIC: 244487.

Francis, A.J.; Gillow, J.B.; and Giles M.R. 1997. Microbial Gas Generation Under 171062 Expected Waste Isolation Pilot Plant Repository Conditions. SAND96-2582. Albuquerque, New Mexico: Sandia National Laboratories.

ACC: MOL.20040805.0364.

Francis, A.J.; Gillow, J.B.; Dodge, C.J.; Dunn, M.; Mantione, K.; Strietelmeier, 171078 B.A.; Pansoy-Hjelvik, M.E.; and Papenguth, H.W. 1998. "Role of Bacteria as Biocolloids in the Transport of Actinides from a Deep Underground Radioactive Waste Repository." Radiochimica Acta, 82, 347-354. München, Germany: R. Oldenbourg Verlag. TIC: 256386.

Francis, A.J.; Gillow, J.B.; Dodge, C.J.; Harris, R.; Beveridge, T.J.; and Papenguth, 171467 H.W. 2004. "Uranium Association with Halophilic and Non-Halophilic Bacteria and Archaea." Radiochimica Acta, 92, 481-488. München, Germany: Oldenbourg Wissenschaftsverlag. TIC: 256482.

Gillow, J.B.; Dunn, M.; Francis, A.J.; Lucero, D.A.; and Papenguth, H.W. 2000. 171096 "The Potential Role of Subterranean Microbes in Facilitating Actinide Migration at the Grimsel Test Site and Waste Isolation Pilot Plant." Radiochimica Acta, 88, 769-774. München, Germany: Oldenbourg Wissenchaftsverlag. TIC: 256385.

Haldeman, D.L. and Amy, P.S. 1993. "Bacterial Heterogeneity in Deep Subsurface 145228 Tunnels at Rainier Mesa, Nevada Test Site.” Microbial Ecology, 25, (2), 185-194. New York, New York: Springer-Verlag. TIC: 238373.

Haveman, S.A.; Stroes-Gascoyne, S.; and Hamon, C.J. 1995. The Microbial 171097 Population in Buffer Materials. AECL TR-654. Pinawa, Manitoba, Canada: Atomic Energy of Canada Limited. TIC: 219285. 
Hennig, C.; Panak, P.J.; Roßberg, A.; Raff, J.; Selenska-Pobell, S.; Matz, W.;

Bucher, J.J.; Bernhard, G.; and Nitsche, H. 2001. "EXAFS Investigation of

Uranium(VI) Complexes formed at Bacillus Cereus and Bacillus Sphaericus

Surfaces." Radiochimica Acta, 89, 625-631. München, Germany: Oldenbourg

Wissenschaftsverlag. TIC: 256434.

Hersman, L. 1995. Microbial Effects on Colloidal Agglomeration. LA-12972-MS.

100750

Los Alamos, New Mexico: Los Alamos National Laboratory.

ACC: MOL.19971210.0253.

Hersman, L.E. 1997. "Subsurface Microbiology: Effects on the Transport of

100763

Radioactive Wastes in the Vadose Zone." Chapter 16 of The Microbiology of the

Terrestrial Deep Subsurface. Amy, P.S. and Haldeman, D.L., eds. Boca Raton, Florida: CRC Lewis Publishers. TIC: 232570.

Hersman, L.E.; Palmer, P.D.; and Hobart, D.E. 1993. "The Role of Siderophores in

100762 the Transport of Radionuclides." Scientific Basis for Nuclear Waste Management XVI, Symposium held November 30-December 4, 1992, Boston, Massachusetts. Interrante, C.G. and Pabalan, R.T., eds. 294, 765-770. Pittsburgh, Pennsylvania: Materials Research Society. TIC: 208880.

Horn, J.; Carrillo, C.; and Dias, V. 2003. "Comparison of the Microbial Community 167221 Composition at Yucca Mountain and Laboratory Test Nuclear Repository Environments." Corrosion/2003, 58th Annual Conference \& Exposition, March 16-20, 2003, San Diego, California. Paper No. 03556. Houston, Texas: NACE International. TIC: 255527.

Horn, J.M. and Meike, A. 1995. "Microbial Activity at Yucca Mountain." Part I: 100765 Microbial Metabolism, Adaptation and the Repository Environment. UCRL-ID-122256. Livermore, California: Lawrence Livermore National Laboratory. TIC: 222145.

Horn, J.M.; Masterson, B.A.; Rivera, A.; Miranda, A.; Davis, M.A.; and Martin, S. 171058 2004. "Bacterial Growth Dynamics, Limiting Factors, and Community Diversity in a Proposed Geological Nuclear Waste Repository Environment." Geomicrobiology Journal, 21, 273-286. London, England: Taylor \& Francis Group. TIC: 256356.

Humphreys, P.; McGarry, R.; Hoffmann, A.; and Binks, P. 1997. "DRINK: A Biogeochemical Source Term Model for Low Level Radioactive Waste Disposal Sites." FEMS Microbiology Reviews, 20, 557-571. New York, New York: Elsevier. TIC: 256372.

Jewett, D.G.; Logan, B.E.; Arnold, R.G.; and Bales, R.C. 1999. “"Transport of 154325 Pseudomonas Fluorescens Strain P17 Through Quartz Sand Columns as a Function of Water Content." Journal of Contaminant Hydrology, 36, (1-2), 73-89. New York, New York: Elsevier. TIC: 249653. 
Johnson, J.E.; Svalberg, S.; and Paine, D. 1974. The study of Plutonium in aquatic systems of the Rocky Flats Environs. Fort Collins, Colorado: Colorado State University. On Order

Kelly, S.D.; Kemner, K.M.; Fein, J.B.; Fowle, D.A.; Boyanov, M.I.; Bunker, B.A.; 171135 and Yee, N. 2002. "X-ray Absorption Fine Structure Determination of pH-Dependent U-Bacterial Cell." Geochimica et Cosmochimica Acta, 66, (22), 3855. New York, New York: Pergamon. TIC: 256373.

Kieft, T.L.; Amy, P.S.; Brockman, F.J.; Fredrickson, J.K.; Bjornstad, B.N.; and 100766 Rosacker, L.L. 1993. "Microbial Abundance and Activities in Relation to Water Potential in the Vadose Zones of Arid and Semiarid Sites." Microbial Ecology, 26, 59-78. New York, New York: Springer-Verlag. TIC: 236436.

Kieft, T.L.; Kovacik, W.P., Jr.; Ringelberg, D.B.; White, D.C.; Haldeman, D.L.; Amy, P.S.; and Hersman, L.E. 1997. "Factors Limiting Microbial Growth and Activity at a Proposed High-Level Nuclear Repository, Yucca Mountain, Nevada.' Applied and Environmental Microbiology, 63, (8), 3128-3133. Washington, D.C.: American Society for Microbiology. TIC: 236444.

Kieft, T.L.; Murphy, E.M.; Haldeman, D.L.; Amy, P.S.; Bjornstad, B.N.; McDonald, 171098 E.V.; Ringelberg, D.B.; White, D.C.; Stair, J.; Griffiths, R.P.; Gsell, T.C.; Holdben, W.E.; and Boone, D.R. 1998. "Microbial Transport, Survival, and Succession in a Sequence of Buried Sediments." Microbiology Ecology, 36, 336-348. New York, New York: Springer-Verlag. TIC: 256410.

Kornberg, A. 1995. "Inorganic Polyphosphate: Toward Making a Forgotten 171079 Polymer Unforgettable." Journal of Bacteriology, 177, (3), 491-496. Washington, D.C.: American Society for Microbiology. TIC: 256416.

Korom, S.F. 1992. "Natural Denitrification in Saturated Zone: A Review." Water 172324 Resources Research, 28, (6), 1657-1668. Washington, D.C.: American Geophysical Union. TIC: 256718.

Kotra, J.P.; Lee, M.P.; Eisenberg, N.A.; and DeWispelare, A.R. 1996. Branch Technical Position on the Use of Expert Elicitation in the High-Level Radioactive Waste Program. NUREG-1563. Washington, D.C.: U.S. Nuclear Regulatory Commission. TIC: 226832.

Lane, D.J.; Pace, B.; Olsen, G.J.; Stahl, D.A.; Sogin, M.L.; and Pace, N.R. 1985.

"Rapid Determination of 16S Ribosomal RNA Sequences for Phylogenetic Analyses." Proceedings of the National Academy of Sciences, 82, 6955-6959. Washington, D.C.: National Academy of Sciences. TIC: 256441. 
Little, B.J.; Wagner, P.A.; and Lewandowski, Z. 1997. "Spatial Relationships

100774

Between Bacteria and Mineral Surfaces." Chapter 4 of Geomicrobiology:

Interactions Between Microbes and Minerals. Banfield, J.F. and Nealson, K.H., eds. Reviews in Mineralogy Volume 35. Washington, D.C.: Mineralogical Society of

America. TIC: 236757.

Lovley D.R. and Phillips, E.J.P. 1988. "Manganese Inhibition of Microbial Iron

Reduction in Anaerobic Sediments." Geomicrobiology Journal, 6, 145-155.

London, England: Taylor \& Francis. TIC: 256429.

Lüdemann, H.; Arth, I.; and Liesack, W. 2000. "Spatial Changes in the Bacterial

171074

Community Structure along a Vertical Oxygen Gradient in Flooded Paddy Soil

Cores." Applied and Environmental Microbiology, 66, (2), 754-762. Washington,

D.C.: America Society for Microbiology. TIC: 256374.

Madigan, M.T.; Martinko, J.M.; and Parker, J. 2003. Brock Biology of

171083

Microorganisms. 10th Edition. Upper Saddle River, New Jersey: Prentice Hall.

TIC: 256412.

McKinley, I.G.; Hagenlocher, I.; Alexander, W.R.; and Schwyn, B. 1997.

100796

"Microbiology in Nuclear Waste Disposal: Interfaces and Reaction Fronts." FEMS

Microbiology Reviews, 20, (3-4), 545-556. Amsterdam, The Netherlands: Elsevier.

TIC: 235823.

Means, J.L. 1982. The Organic Geochemistry of Deep Ground Waters. ONWI-268.

171136

Columbus, Ohio: Battelle Columbus Laboratories, Office of Nuclear Waste

Isolation. ACC: MOL.20041025.0182.

NIST 2003. NIST Critically Selected Stability Constants of Metal Complexes

Database. NIST Standard Reference Database 46 Version 7.0. Gaithersburg, MD:

NIST- U.S. Department of Commerce Technology Administration. On Order

Norwood, D.E. and Gilmour, A. 2001. "The Differential Adherence Capabilities of

Two Listeria Monocytogenes Strains in Monoculture and Multispecies Biofilms as a Function of Temperature." Letters in Applied Microbiology, 33, 320-324. Oxford, England: Blackwell Publishing. TIC: 256415.

NRC (U.S. Nuclear Regulatory Commission) 2003. Yucca Mountain Review Plan, Final Report. NUREG-1804, Rev. 2. Washington, D.C.: U.S. Nuclear Regulatory Commission, Office of Nuclear Material Safety and Safeguards. TIC: 254568.

Overbeck, J.; Dijkhuizen, L.; and Romanovskaya, V. 1997. "Investigation of the Effect of Prolonged Nuclear Radiation on the Aboriginal Bacterial Populations in the Zone of the Chernobyl Atomic Power Station Castastrophe." INTAS-94-2825. Belgium, Brussels: INTAS. Accessed August 10, 2004. TIC: 256400.

http://www.intas.be/catalog/94-2825.htm 
Panak, P.; Selenska-Pobell, S.; Kutschke, S.; Geipel, G.; Bernhard, G.; and Nitsche, 171085 H. 1999. "Complexation of U(VI) with Cells of Thiobacillus Ferrooxidans and Thiomonas Cuprina of Different Geological Origin." Radiochimica Acta, 84, 183-190. München, Germany: Oldenbourg Wissenchaftsverlag. TIC: 256430.

Panak, P.J.; Booth, C.H.; Caulder, D.L.; Bucher, J.J.; Shuh, D.K.; and Nitsche, H. 2002. "X-Ray Absorption Fine Structure Spectroscopy of Plutonium Complexes with Bacillus Sphaericus." Radiochimica Acta, 90, 315-321. München, Germany: Oldenbourg Verlage. TIC: 256432.

Patel, J.B.; Leonard, D.G.B.; Pan, X.; Musser, J.M.; Berman, R.E.; and Nachamkin, 171100 I. 2000. "Sequence-Based Identification of Mycobacterium Species Using the MicroSeq 500 16S rDNA Bacterial Identification System.” Journal of Clinical Microbiology, 38, (1), 246-251. Washington, D.C.: American Society for Microbiology. TIC: 256375.

Pedersen, K. 1996. "Investigations of Subterranean Bacteria in Deep Crystalline 171086 Bedrock and their Importance for the Disposal of Nuclear Waste." Canadian Journal of Microbiology, 42, 382-391. Ottawa, Ontario, Canada: National Research Council of Canada. TIC: 256424.

Pedersen, K. 1999. "Subterranean Microorganisms and Radioactive Waste Disposal in Sweden." Engineering Geology, 52, 163-176. New York, New York: Elsevier. TIC: 244755.

Pedersen, K. and Karlsson, F. 1995. Investigations of Subterranean 100810 Microorganisms: Their Importance for Performance Assessment of Radioactive Waste Disposal. SKB 95-10. Stockholm, Sweden: Swedish Nuclear Fuel and Waste Management Company. TIC: 221443.

Pedersen, K.; Arlinger, J.; Ekendahl, S.; and Hallbeck, L. 1996. "16S rRNA Gene 171101 Diversity of Attached and Unattached Bacteria in Boreholes along the Access Tunnel to the Aspö Hard Rock Laboratory, Sweden." FEMS Microbiology Ecology, 19, 249-262. New York, New York: Elsevier. TIC: 256414.

Pedersen, K.; Arlinger, J.; Hallbeck, L.; and Pettersson, C. 1996. "Diversity and 171103 Distribution of Subterranean Bacteria on Ground Water at Oklo in Gabon, Africa, as Determined by 16S-rRNA Gene Sequencing." Molecular Ecology, 5, 427-436. Oxford, England: Blackwell Science. TIC: 256418.

Perrot, F.; Jouenne, T.; Feuilloley, M.; Vaudry, H.; and Junter, G.A 1998. "Gel 171124 Immobilization Improves Survival of Eschericia Coli Under Temperature Stree in Nutrient-Poor Natural Water." Pergamon, 32, (12), 3521-3526. New York, New York: Pergamon. TIC: 256376. 
Pitonzo, B.J.; Amy, P.S.; and Rudin, M. 1999. "Effect of Gamma Radiation on

Native Endolithic Microorganisms from a Radioactive Waste Deposit Site."

Radiation Research, 152, 64-70. New York, New York: Radiation Research

Society. TIC: 248156.

Ringelberg, D.B.; Amy, P.S.; Clarkson, W.W.; Haldeman, D.L.; Khalil, M.K.; Kieft, 100824

T.L.; Krumholtz, L.R.; Stair, J.O.; Suflita, J.M.; White, D.C.; and Hersman, L.E.H. 1997. Microbial Community Composition in a Volcanic Tuff, Yucca Mountain, Nevada. Rough draft. Vicksburg, Mississippi: U.S. Army Corps of Engineers Waterways Experiment Station. TIC: 234025.

Russell, C.; Jacobsen, R.; Haldeman, D. L.; and Amy, P. S. 1994. "Heterogeneity of 119578 Deep Subsurface Microorganisms and Correlations to Hydrogeological and Geochemical Parameters." Geomicrobiology Journal, 12, 37-51. London, England: Taylor \& Francis. TIC: 246865.

Stackebrandt, E. and Goebel, B.M. 1994. "Taxonomic Note: A Place for 171105 DNA-DNA Reassociation and 16S rRNA Sequence Analysis in the Present Species Definition in Bacteriology." International Journal of Systematic Bacteriology, 44, (4), 846-849. Washington, D.C.: American Society for Microbiology.

TIC: 256427.

Stone, A.T. 1997. "Reactions of Extracellular Organic Ligands with Dissolved Metal Ions and Mineral Surfaces." Chapter 9 of Geomicrobiology: Interactions Between Microbes and Minerals. Banfield, J.F. and Nealson, K.H., eds. Reviews in Mineralogy Volume 35. Washington, D.C.: Mineralogical Society of America. TIC: 236757.

Stroes-Gascoyne S. 1996. "Microbial Studies in the Canadian Nuclear Fuel Waste 171851 Management Program." High Level Radioactive Waste Management, Proceedings of the Seventh Annual International Conference, Las Vegas, Nevada, April 29-May 3, 1996. Pages 4-6. La Grange Park, Illinois: American Nuclear Society. TIC: 226494.

Stroes-Gascoyne, S.; Pedersen, K.; Haveman, S.A.; Dekeyser, K.; Arlinger, J.; 171108 Daumas, S.; Ekendahl, S.; Hallbeck, L.; Hamon, C.J.; Jahromi, N.; and Delaney, T-L. 1997. "Occurrence and Identification of Microorganisms in Compacted Clay-Based Buffer Material Designed for Use in a Nuclear Fuel Waste Disposal Vault." Canadian Journal of Microbiology, 43, 1133-1146. Ottawa, Ontario, Canada: National Research Council of Canada. TIC: 256425.

Tunlid, A. and White, D.C. 1992. "Biochemical Analysis of Biomass, Community Structure, Nutritional Status, and Metabolic Activity of Microbial Communities in Soil.” Soil Biochemistry, 7, 229-262. New York, New York: Marcel Dekker. TIC: 246536. 
Van Cappellen, P. and Wang, Y. 1996. "Cycling of Iron and Manganese in Surface 171128 Sediments: A General Theory for the Coupled Transport and Reaction of Carbon, Oxygen, Nitrogen, Sulfur, Iron, and Manganese.” American Journal of Science, 296, 197-243. New Haven, Connecticut: Yale University, Kline Geology Laboratory. TIC: 256367.

van Waasbergen, L.G.; Balkwill, D.L.; Crocker, F.H.; Bjornstad, B.N.; and Miller, 171075 R.V. 2000. "Genetic Diversity among Arthrobacter Species Collected Across a Heterogeneous Series of Terrestrial Deep-Surface Sediments as Determined on the Basis of 16S rRNA and recA Gene Sequences." Applied and Environmental Microbiology, 66, (8), 3454-3463. Washington, D.C.: American Society for Microbiology. TIC: 256377.

Wang, Y. and Papenguth, H.W. 2001. "Kinetic Modeling of Microbially-Driven Redox Chemistry of Radionuclides in Subsurface Environments; Coupling Transport, Microbial Metabolism and Geochemistry." Journal of Contaminant Hydrology, 47, 297-309. New York, New York: Elsevier. TIC: 256378.

Wang, Y. and Van Cappellen, P. 1996. "A Multicomponent Reactive Transport Model of Early Diagenesis: Application to Redox Cycling in Coastal Marine Sediments." Geochemica et Cosmochimica Acta, 60, (16), 2993-3014. New York, New York: Pergamon. TIC: 256357.

Wang, Y.; Brush, L.H.; and Bynum, R.V. 1997. "Use of MgO to Mitigate the Effect of Microbial $\mathrm{CO}_{2}$ Production in the Waste Isolation Pilot Plant." WM'97 Proceedings, March 2-6, 1997, Tucson, Arizona, HLW, LLW, Mixed Wastes and Environmental Restoration - Working Towards a Cleaner Environment. La Grange Park, Illinois: American Nuclear Society. TIC: 256402.

West, J.M.; Christofi, N.; and Arme, S.C. 1986. "The Influence of Groundwater and 171088 Extreme Environments on Microbial Activity and Radionuclide Transport." The Effects of Natural Organic Compounds and Microorganisms on Radionuclide Transport, Proceedings of an NEA Workshop held in Paris on 12th June, 1985. Pages 19-38. Paris, France: Organisation for Economic Co-operation and Development. TIC: 256686. Copyright Requested

West, J.M.; Christofi, N.; and McKinley, I.G. 1985. "An Overview of Recent 110047 Microbiological Research Relevant to the Geological Disposal of Nuclear Waste." Radioactive Waste Management and the Nuclear Fuel Cycle, 6, (1), 79-95. New York, New York: Harwood Academic Publishers. TIC: 244498.

West, J.M.; McKinley, I.G.; and Vialta, A. 1992. "Microbiological Analysis at the Poços de Caldas Natural Analogue Study Sites." Journal of Geochemical Exploration, 45, 439-449. Amsterdam, The Netherlands: Elsevier. TIC: 256413. 


\subsection{CODES, STANDARDS, REGULATIONS, AND PROCEDURES}

10 CFR 63. Energy: Disposal of High-Level Radioactive Wastes in a Geologic

Repository at Yucca Mountain, Nevada. Readily available.

AP-2.14Q, Rev. 3, ICN 0. Document Review. Washington, D.C.: U.S. Department of Energy, Office of Civilian Radioactive Waste Management.

ACC: DOC.20030827.0018.

AP-3.15Q, Rev. 4, ICN 5. Managing Technical Product Inputs. Washington, D.C.: U.S. Department of Energy, Office of Civilian Radioactive Waste Management.

ACC: DOC.20040812.0004.

AP-SIII.9Q, Rev. 1, ICN 7. Scientific Analyses. Washington, D.C.: U.S.

Department of Energy, Office of Civilian Radioactive Waste Management.

ACC: DOC.20040920.0001.

AP-SV.1Q, Rev. 1, ICN 1. Control of the Electronic Management of Information. Washington, D.C.: U.S. Department of Energy, Office of Civilian Radioactive Waste Management. ACC: DOC.20040308.0001.

LP-SA-001Q-BSC, Rev. 0. Determination of Importance and Site Performance Protection Evaluations. Washington, D.C.: U.S. Department of Energy, Office of Civilian Radioactive Waste Management. ACC: MOL.20020510.0386.

\subsection{SOURCE DATA, LISTED BY DATA TRACKING NUMBER}

GS011108312322.006. Field and Chemical Data Collected between 1/20/00 and 162911 4/24/01 and Isotopic Data Collected between 12/11/98 and 11/6/00 from Wells in the Yucca Mountain Area, Nye County, Nevada. Submittal date: 11/20/2001.

LL021007312251.020. Yucca Mountain Rock Bacterial Community

Characterization Data. Submittal date: 12/11/2002.

LL040801512251.115. Bacterial Growth Dynamics, Limiting Factors, and 171476 Community Diversity in a Proposed Geological Nuclear Waste Repository Environment. Submittal date: 08/18/2004.

LL981209705924.059. Biochemical Contributions to Corrosion of Carbon Steel and 110317 Alloy 22 in a Continual Flow System. Submittal date: 12/15/1998.

MO0006J13WTRCM.000. Recommended Mean Values of Major Constituents in 151029 J-13 Well Water. Submittal date: 06/07/2000.

MO0407SEPFEPLA.000. LA FEP List. Submittal date: 07/20/2004. 
SN0407T0510102.017. In-Drift Gas Flux and Oxygen Demand. Submittal date:

$07 / 16 / 2004$. 


\section{INTENTIONALLY LEFT BLANK}

